\title{
Anthropogenic Impacts on Soils of Wadi Al-Molak, Suez Canal West, Egypt
}

\author{
Adel A. Elwan \\ Pedology Department, Water Resources and Desert Soils Division, Desert Research Center (DRC), Cairo, 11753, Egypt
}

Received: $15 / 7 / 2018$

\begin{abstract}
The past three decades saw rapid and massive agriculture in Wadi Al-Molak at west of Suez Canal, Egypt. Land cover and pedon changes were studied in $850 \mathrm{~km}^{2}$ of the Wadi Al-Molak catena using time series and paired-site approach, respectively. The aim was to better understand the anthropogenic impacts responsible for the change of land cover and soil characteristics vertically within pedons and horizontally across landscapes under different ages of cultivation. Five landscapes were recognized: mountains and piedmont slope at upland; alluvial plain at midland; bajada plain and Nile old deltaic plain at lowland. The available Landsat images were analyzed from December 1986 to December 2016 of the Wadi to track the agrarian expansions in epochs (till 1986, 1987-1996, 1997-2006, and 2007 2016). Forty-three pedons were randomly distributed throughout the five landscapes representing both of cultivated soils under all periods and native soils. Detailed soil morphological as well as selected physical and chemical characteristics were studied. Soil morphology and taxonomy from five landscapes were used to interpret the anthropogenic impacts. Landscapes and soils were altered by conversion to agriculture for direct human use. Among out key findings are that (1) the agricultural areas increased from $225 \mathrm{~km}^{2}$ in 1986 to $475 \mathrm{~km}^{2}$ in 2016 while the annual expansion rate decelerated from $11.8 \mathrm{~km}^{2} \mathrm{yr}^{-1}$ in 1996 to $2.2 \mathrm{~km}^{2} \mathrm{yr}^{-1}$ in 2016; (2) the majority of agrarian expansions during 1987-2016 mainly occurred on alluvial plain landscape; (3) availability of irrigation water, soil potentialities, and national policies were the major driving forces; (4) solum horizons and redoximorphic/ped surface features occurred in cultivated soils and absent in native soils; (5) soil moisture regime was changed to anthraquic under sustained paddy cultivation, suggesting a modification in USDA Soil Taxonomy; (6) soil solum thickness increased with increasing time of cultivation; (7) formation of salic and natric horizons with high soil bulk density in lowland indicated soil degradation process as a result of mismanagement; (8) pedons under cultivation contained greater concentrations of organic carbon, total nitrogen, and clay than pedons under natural vegetation; and (9) the cultivated soils were classified as Aridisols or Vertisols while the native soils were classified as Entisols. The results demonstrated that agricultural expansion had changed the land cover, soil morphological, physical, and chemical properties, even the soil types. These results are very valuable for better understanding soil genesis and evolution with agricultural utilization.
\end{abstract}

Keywords: Pedon, landscape change, soil change, anthropedogenesis

\section{INTRODUCTION}

Humans are having an ever-increasing impact on soils and landscapes (Grieve, 2001). Agricultural practices and soil management are the more significant anthropogenic activities that disturb the morphology, physical, and chemical characteristics of soil (Zilverberg et al., 2018); which by being inadequate, leading to soil degradation (Khresat et al., 2008). The soil is not static but is subject to natural or anthropogenic changes (Kołodyńska-Gawrysiak et al., 2017). These include both directional and cyclic changes (Kołodyńska-Gawrysiak et al., 2017). Changes can occur over time scales ranging from days to millennia. Impacts of human activity are superimposed on these natural changes and their significance must be evaluated in the light of natural changes (Zilverberg et al., 2018). Assessment of the sensitivity of the soil and landscape to further change must also take account of natural variability in both space and time (Grieve, 2001).

Land use change or land cover change typically refers to changing from one type of vegetation cover to another (e.g., natural vegetation to cropland) (Chirinda et al., 2014). Cultivation can cause large changes to physical, chemical, and biological properties within the surface horizon (Zilverberg et al., 2018). The spatial and temporal distribution of land use and land cover (LULC) using satellite images is crucial to understanding the phenomenon of environmental change. Landuse pattern is a reflection of human activities within the boundaries of climatic and edaphic factors (Chirinda et al., 2014). Anthropogenic soil change should continue to be studied and assessed to allow for better quantification of the impacts on soil formation and ecosystem services (Zilverberg et al., 2018).

Soil change refers to the variation of soil properties in one location over time (Tugel et al., 2008). The concept of soil change has been proposed as a framework for understanding and documenting the impact of human use and management on soil properties and function (Tugel et al., 2005, 2008). Management of soil resources, directly or indirectly, can alter soil properties and soil functions both negatively and positively. Native and cultivated landscapes must be compared to provide an accurate measure of soil change resulting from land use, cultivation, and accelerated erosion, and depth distribution functions depict changes in soil properties with depth (Indorante et al., 2014). Many natural soil chronosequences have been studied to illustrate temporal changes in soil properties and the rates of soil forming processes (e.g. Trimble, 1974; Zilverberg et al., 2018). However, very few such studies have involved anthropogenic soils (Huang et al., 2015). Because of the widely recognized extensive and intensive anthropogenic influences on soils in the Anthropocene (Crutzen, 2006), human forcings have been considered as a fully-fledged soil-forming factor 
(Dudal, 2005). Yet little is known about the anthropedogenesis due at least partly to the lack of welldated chronosequences for the diverse anthropogenic soils on earth. A review conducted by Trimble (1974) documented the impact of humans on landscapes of the southern piedmont where almost 200 years of land use have significantly altered the soil landscape. Indorante et al. (2014) quantified the soil profile change caused by land use in Central Missouri Loess Hillslopes. They showed a distinct downward migration of the native A horizon into the subsurface layer and subsoil in the soils on cultivated hillslopes and highlights the importance of studying the complete soil solum when modeling and quantifying soil change. Kołodyńska-Gawrysiak et al. (2017) studied the impact of natural and anthropogenic processes on the evolution of closed depressions in loess areas. Zilverberg et al. (2018) quantified the legacy effects of farming at four upland landscape positions and three lowland positions.

Landscape position regulates the local redistribution of water, clays, ions, and minerals (Jenny, 1941). In this study, changes in the morphological, physical, and chemical properties of the pedon were examined by comparing properties of the cultivated soils under irrigation with those of the native lands under natural vegetation across landscape positions. Furthermore, the interdisciplinary investigations of socioeconomic and environment have been conducted in the representative Wadi Al-Molak, Suez Canal West, Egypt. This study differs from previous studies by concurrently examining changes in both land cover and pedon characteristics across the toposequence caused by humans, with incorporating natural impacts on native soils. Specific objectives of this research were: (i) to detect the spatiotemporal changes in the land use/land cover of Wadi Al-Molak from 1986 to 2016, and thereby identify the driving forces responsible for these changes; (ii) to evaluate the differences in soil morphological, physical, and chemical properties for cultivated and native (virgin) pedons; (iii) to understand the relevant processes responsible for the distribution of soil morphology and taxa across the studied landscapes; and (iv) to estimate the effects of continuous cultivation as anthropogenic impacts on pedon horizonation overtime.

\section{MATERIALS AND METHODS}

\section{Study site}

The study was conducted in $850 \mathrm{~km}^{2}$ watershed of Wadi Al-Molak (Table 1), east of Nile Delta, located on Suez Canal west, Egypt (Fig. 1). Wadi Al-Molak is an open drainage system which drains into the Nile Delta. It is located between $30^{\circ} 14^{\square} 30^{\square}$ to $30^{\circ} 34^{\prime} 30^{\square}$ North latitudes and $31^{\circ} 39^{\prime} 30^{\square}$ to $32^{\circ} 1^{\prime} 45^{\square}$ East longitudes (Fig. 1) and extends from the southeastern part of the mountains to the east of Nile Delta in the north of study area. The terrain slopes gently northward to the Ismailia canal and Wadi Toumilat. There are major Wadis pouring into Wadi Al-Molak; e.g., Wadi Sakrán, Wadi Al-Áwásig, and Wadi Muftáh which receive rainfall from different mountains; e.g., Al-Girba,
Mashash Al-Áwásig, and Umm-Raqm at higher slopes and empty into the Nile delta basin at lower slopes (Fig. 1). It is characterized by an arid to a hyper-arid climate with dry summers and wet winters (Egyptian Meteorological Authority, 2016). The transect spans a broad environmental gradient, with variation in mean annual soil temperature $\left(21-37^{\circ} \mathrm{C}\right)$. Accordingly, soil temperature regime ranges from thermic to hyperthermic with increasing elevation. Mean annual precipitation commonly varies between 21 and $39 \mathrm{~mm}$ and occurs predominantly during the winter months, which yields an aridic soil moisture regime. Relative humidity ranges from 45 to $57 \%$, while the evaporation rate is very high $(8-17 \mathrm{~mm} /$ day $)$.

Water resources in Wadi Al-Molak are the surface water and groundwater. The surface water is from the Nile River through Ismailia canal and its branches (i.e., Al-Shabab canal) (Khalaf and Gad, 2015). The water-bearing formations in the Wadi AlMolak comprise the aquifers of Quaternary and Miocene (Gad et al., 2015). The aquifer is thought to be recharged mainly by the seepage from Ismailia canal and excess irrigation of the reclaimed lands (Khalil et al., 2015). In the narrow strip adjacent to the Ismailia canal, the depth to the groundwater is highly affected by the surface water running in the canal. The groundwater quality of the Quaternary aquifer has been affected by human activities (i.e., industrial, domestic, and agricultural projects) (Khalil et al., 2015).

In the geological viewpoint, Wadi Al-Molak is a sedimentary basin filled out with alluvial and lithic materials of different origins such as igneous, metamorphic, and sedimentary rocks (Stanley and Wrane, 1993; Mabrouk, et al., 2016). These rocks appear in different forms and weathering stages and form a thick mantle above the bedrock (Shata and ElFayoumy, 1970; El-Shazly et al., 1975; Stanley and Wrane, 1993; Mabrouk et. al., 2016). The various rock types outcropping in the area produced different soils on several landscape positions. It starts from the tertiary rocks of southern mountainous and rocky terrains at summit, shoulder, and backslopes, then goes through the mixed sedimentary areas in the footslope, and finally ends with the quaternary sediments at the toeslope in the north (El-Shazly et al., 1975, Said, 1993, Mabrouk et al., 2016). Tertiary rocks are represented by Pliocene, Miocene, Oligocene, and Eocene rocks. Miocene sediments are made up of coarse sand and flint pebbles intercalated with sandy limestone and sandy marl of shallow marine origin (El-Shazly et al., 1975). Scattered bedrock exposures in backslope include Cenozoic basaltic flows overlain by a carbonate unit. Oligocene sediments are composed of sand and gravels (Said, 1993). On the other hand, Quaternary deposits are classified, from the base to the top, into Pleistocene and Recent Holocene. Quaternary sediments cover a major part of the study area which derived from different two sources which are (i) Nile deposits of Nile silt, fine sand, and clay belong to Middle Pleistocene-aged Prenile and Late Pleistocene-Holocene-aged Neonile (Abd-Allah et al., 2012; El-Bastawesy et al., 2016), and (ii) Holocene Wadi deposits (Said, 1993; Geological 
Survey and Mining Authority, 1981). These sediments were intermixed at toeslope landscape position. Fine sediments of the Nile old deltaic plain were covered by recently transported coarse materials of the desert hydrographic basins, which yield a buried soil.

\section{Landscapes of Wadi Al-Molak}

The site included different major landscapes across an elevation gradient (between 7 and $137 \mathrm{~m}$ MTL) (Table 2) on the catena of Wadi Al-Molak. These landscapes were recognized, delineated, and mapped (Fig. 1) via a GIS software based on the satellite imageries obtained from 1986 to 2016 (Fig. 2). They have been classified into five landscapes from downslope to upslope: Nile old deltaic plain $\left(67 \mathrm{~km}^{2}\right)$ and bajada plain $\left(87 \mathrm{~km}^{2}\right)$ at lowland, alluvial plain (400 $\left.\mathrm{km}^{2}\right)$ at midland, besides piedmont slope $\left(185 \mathrm{~km}^{2}\right)$ and mountains $\left(111 \mathrm{~km}^{2}\right)$ at upland (Fig. 1 and Tables 1, 2). These landscapes were subdivided into specific landforms and geomorphic components using the taxonomic logic of Peterson (1981) and terms consistent with Wysocki et al. (2000), Schoeneberger et al., (2012), and Soil Science Division Staff (2017), where applicable (Table 2). The original landscapes were subjected to the local modifications by anthropogenic activities. For instance, the Nile old deltaic plain, bajada plain, and most alluvial plain lands were removed and the land was leveled and reclaimed (Table 2).

\section{Remotely sensed data acquisition}

Confirmation of land cover change as a natural or an anthropogenic impact is made from the Landsat imagery itself, with the aide of field verification and assessment at targeted locations. In order to study LULC change in Wadi Al-Molak, the multispectral satellite images of the Wadi were acquired for four epochs with ten-year increments (till December 1986, January 1987-December 1996, January 1997- December 2006, and January 2007-December 2016) (Fig. 2). Landsat images were obtained for the months of January and December from United States Geological Survey
(USGS) (http://glovis.usgs.gov). Landsat 7 ETM+ imagery was selected because of its long temporal archive and because it can be easily acquired at no cost. Landsat 7 continually acquired imagery from December 1986 until December 2016 on a 16-day revisit basis with nominal ground pixel sizes of $30 \mathrm{~m}$ over a $185 \times$ $185 \mathrm{~km}$ area. Spectral bands used in this research included blue-green (450-520 nm), green (520-600 $\mathrm{nm})$, red (630-690 nm), and near-infrared (NIR, 760$900 \mathrm{~nm})$. The time series profiles were used in the evaluation of land cover change as determined by comparing multi-temporal images (Fig. 2). The ground truth datasets included GPS locations, photographs, landscape records, and high-resolution Google Earth images for each period.

The age of cultivation for each period was calculated as follows: $>30$ year for the soils cultivated before 1987 (December 1986), 30-21 year for the soils cultivated within the period from January 1987 to December 1996, 20-11 year for the soils cultivated within the period from January 1997 to December 2006, $\leq 10$ years for the soils cultivated within the period from January 2007 to December 2016.

The annual expansion rate of agricultural or urban land $\left(\mathrm{ER}, \mathrm{km}^{2} \mathrm{yr}^{-1}\right)$ was calculated by the equation: expansion rate $(\mathrm{ER})=(\mathrm{St} 2-\mathrm{St} 1) / \Delta \mathrm{t}$ (Kuang et al., 2016), where St 2 and $\mathrm{St} 1$ are the total crop or urban land area $\left(\mathrm{km}^{2}\right)$ in year $\mathrm{t} 2$ and $\mathrm{t} 1$, respectively, and $\Delta \mathrm{t}$ is the number of years between $\mathrm{t} 2$ and $\mathrm{t} 1$ (Table 1).

\section{Field work}

Forty-three pedons were randomly distributed throughout the five landscapes (e.g., mountains, piedmont slope, alluvial plain, bajada plain, and Nile old deltaic plain) across a catena in Wadi Al-Molak representing the major land use structure of the site (Figs. 2 and 3). The number of sampling pedons was approximately proportional to the map area of each landscape (Fig. 1).

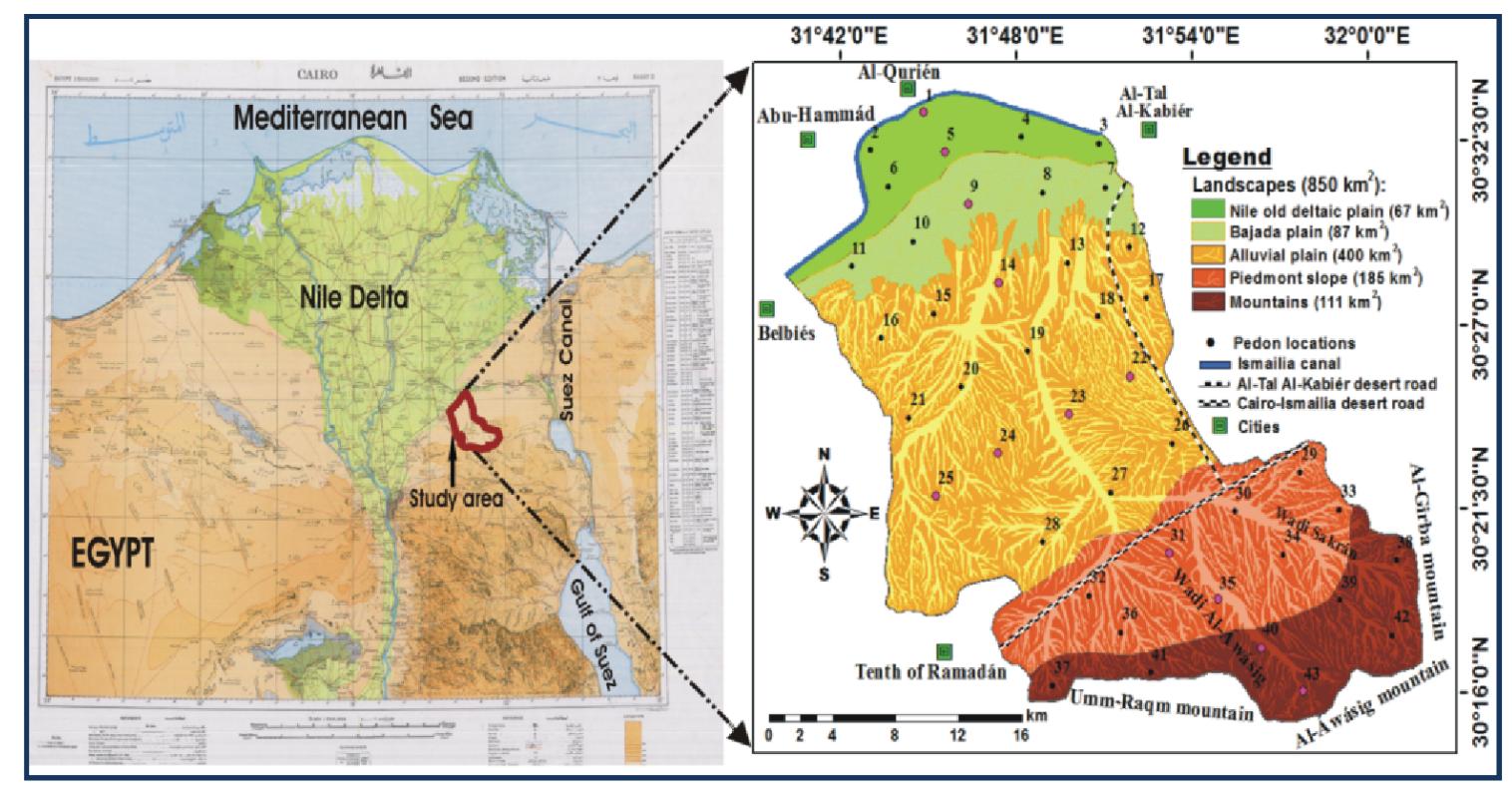

Fig. (1): Location map and distribution of sampling pedons across landscapes in the Wadi Al-Molak basin study area located in the Lower Egypt. Two intersecting transects of pedons location are indicated by pink dots 
Table (1): Distribution of expansion areas of agricultural and urban lands from 1986 to 2016 within the landscapes in Wadi Al-Molak study area

\begin{tabular}{|c|c|c|c|c|c|c|c|c|c|c|c|c|c|c|c|}
\hline \multirow{3}{*}{$\begin{array}{l}\text { Year/ } \\
\text { Period }\end{array}$} & \multirow{3}{*}{$\begin{array}{c}\text { Landuse } \\
\text { activity } \\
\text { (Expansion } \\
\text { area) }\end{array}$} & \multirow{2}{*}{\multicolumn{2}{|c|}{$\begin{array}{c}\text { Total study } \\
\text { area } \\
\left(850 \mathrm{~km}^{2}\right)\end{array}$}} & \multicolumn{10}{|c|}{ Landscapes } & \multirow{2}{*}{\multicolumn{2}{|c|}{$\begin{array}{c}\text { Expansion } \\
\text { rate } \\
\left(\mathbf{k m}^{2} \mathbf{y r}^{-1}\right)\end{array}$}} \\
\hline & & & & \multicolumn{2}{|c|}{$\begin{array}{c}\text { Nile old } \\
\text { deltaic plain } \\
\left(67 \mathrm{~km}^{2}\right)\end{array}$} & \multicolumn{2}{|c|}{$\begin{array}{c}\text { Bajada } \\
\text { plain } \\
\left(87 \mathrm{~km}^{2}\right) \\
\end{array}$} & \multicolumn{2}{|c|}{$\begin{array}{c}\text { Alluvial } \\
\text { plain } \\
\left(400 \mathrm{~km}^{2}\right)\end{array}$} & \multicolumn{2}{|c|}{$\begin{array}{l}\text { Piedmont } \\
\text { slope } \\
\left(185 \mathrm{~km}^{2}\right)\end{array}$} & \multicolumn{2}{|c|}{$\begin{array}{r}\text { Mountains } \\
\left(111 \mathbf{k m}^{2}\right)\end{array}$} & & \\
\hline & & $\mathbf{k m}^{2}$ & $\%$ & $\mathrm{~km}^{2}$ & $\%$ & $\mathrm{~km}^{2}$ & $\%$ & $\mathrm{~km}^{2}$ & $\%$ & $\mathrm{~km}^{2}$ & $\%$ & $\mathrm{~km}^{2}$ & $\%$ & $\mathrm{~km}^{2}$ & $\%$ \\
\hline \multirow{3}{*}{ Till 1986} & $\begin{array}{l}\text { Total } \\
\text { cropland area }\end{array}$ & 225 & 26.5 & 67 & 100 & 68 & 78.2 & 90 & 22.5 & 0 & 0 & 0 & 0 & -- & -- \\
\hline & $\begin{array}{l}\text { Total urban } \\
\text { land area }\end{array}$ & 0 & 0 & 0 & 0 & 0 & 0 & 0 & 0 & 0 & 0 & 0 & 0 & -- & -- \\
\hline & $\begin{array}{l}\text { Not-used } \\
\text { land (native) }\end{array}$ & 625 & 73.5 & 0 & 0 & 19 & 21.8 & 310 & 77.5 & 185 & 100 & 111 & 100 & -- & -- \\
\hline \multirow{5}{*}{$\begin{array}{l}1987- \\
1996\end{array}$} & $\begin{array}{l}\text { Newly } \\
\text { cultivated }\end{array}$ & 118 & 13.9 & 0 & 0 & 19 & 21.8 & 92 & 23 & 7 & 3.8 & 0 & 0 & 11.8 & 1.39 \\
\hline & $\begin{array}{l}\text { Total } \\
\text { cropland area }\end{array}$ & 343 & 40.4 & 67 & 100 & 87 & 100 & 182 & 45.5 & 7 & 3.8 & 0 & 0 & -- & -- \\
\hline & $\begin{array}{l}\text { Added built- } \\
\text { up land }\end{array}$ & 8 & 0.9 & 0 & 0 & 0 & 0 & 0 & 0 & 8 & 4.3 & 0 & 0 & 0.8 & 0.09 \\
\hline & $\begin{array}{l}\text { Total urban } \\
\text { land area }\end{array}$ & 8 & 0.9 & 0 & 0 & 0 & 0 & 0 & 0 & 8 & 4.3 & 0 & 0 & -- & -- \\
\hline & $\begin{array}{l}\text { Not-used } \\
\text { land (native) }\end{array}$ & 499 & 58.7 & 0 & 0 & 0 & 0 & 218 & 54.5 & 170 & 91.9 & 111 & 100 & -- & -- \\
\hline \multirow{5}{*}{$\begin{array}{l}1997- \\
2006\end{array}$} & $\begin{array}{l}\text { Newly } \\
\text { cultivated }\end{array}$ & 110 & 12.9 & 0 & 0 & 0 & 0 & 102 & 25.5 & 8 & 4.3 & 0 & 0 & 11 & 1.29 \\
\hline & $\begin{array}{l}\text { Total } \\
\text { cropland area }\end{array}$ & 453 & 53.3 & 67 & 100 & 87 & 100 & 284 & 71.0 & 15 & 8.1 & 0 & 0 & -- & -- \\
\hline & $\begin{array}{l}\text { Added built- } \\
\text { up land }\end{array}$ & 14 & 1.6 & 0 & 0 & 0 & 0 & 10 & 2.5 & 4 & 2.2 & 0 & 0 & 1.4 & 0.16 \\
\hline & $\begin{array}{l}\text { Total urban } \\
\text { land area }\end{array}$ & 22 & 2.6 & 0 & 0 & 0 & 0 & 10 & 2.5 & 12 & 6.5 & 0 & 0 & -- & -- \\
\hline & $\begin{array}{l}\text { Not-used } \\
\text { land (native) }\end{array}$ & 375 & 44.1 & 0 & 0 & 0 & 0 & 106 & 26.5 & 158 & 85.4 & 111 & 100 & -- & -- \\
\hline \multirow{5}{*}{$\begin{array}{l}2007- \\
2016\end{array}$} & $\begin{array}{l}\text { Newly } \\
\text { cultivated }\end{array}$ & 22 & 2.6 & 0 & 0 & 0 & 0 & 22 & 5.5 & 0 & 0 & 0 & 0 & 2.2 & 0.26 \\
\hline & $\begin{array}{l}\text { Total } \\
\text { cropland area }\end{array}$ & 475 & 55.9 & 67 & 100 & 87 & 100 & 306 & 76.5 & 15 & 8.1 & 0 & 0 & -- & -- \\
\hline & $\begin{array}{l}\text { Added built- } \\
\text { up land }\end{array}$ & 28 & 2.9 & 0 & 0 & 0 & 0 & 25 & 6.3 & 3 & 1.6 & 0 & 0 & 2.5 & 0.29 \\
\hline & $\begin{array}{l}\text { Total urban } \\
\text { land area }\end{array}$ & 50 & 5.9 & 0 & 0 & 0 & 0 & 35 & 8.8 & 15 & 8.1 & 0 & 0 & -- & -- \\
\hline & $\begin{array}{l}\text { Not-used } \\
\text { land (native) }\end{array}$ & 325 & 38.2 & 0 & 0 & 0 & 0 & 59 & 14.8 & 155 & 83.8 & 111 & 100 & -- & -- \\
\hline
\end{tabular}

The soils were collected from north-facing transects that ran perpendicular to the higher slope. Histories of soil change may be difficult to reconstruct, complicated by imprints of multiple land use activities and changing environmental conditions. Therefore, the paired-site approach to evaluating long-term anthropogenic influence on soil has been to identify soils that are relatively undisturbed as in native soils on alluvial plain (pedons 21 and 25) as well as native soils on upland and these soils were used as reference points from which to measure soil change in land cultivated on the same landscape but under different cultivation ages (1987-1996, 1997-2006, and 2007-2016). In this sense, two intersecting transects were used and presented in this study to link all land uses and landscape positions (Figs. 1 and 2). The first transect ran vertically across slope gradient from the north at lower slopes to the south at higher slopes (pedons nos. 1, 5, 9, 14, 23, 31, 35,40 , and 43) to represent all landscape positions including cultivated and native soils while the second transect ran horizontally from the east to the west across alluvial plain landscape to cover the cultivation periods (e.g., pedon 22 for 1987-1996, 23 for 1997-2006, and 24 for 2007-2016) and the native soil was represented by pedon 25 (Figs. 3 and 4).

Soils were sampled by genetic horizon from selected landscapes across environmental gradients. Detailed morphological descriptions of each horizon/layer of representative pedons and their sites were made in the field itself as per the standards procedures given by FAO (2006), Schoeneberger et al. (2012), and Soil Science Division Staff (2017). Soil color was determined for moist samples using the Munsell notation (Munsell Color, 2009). As regolith encompasses in its upper parts the solum (where pedogenic processes and biota are dominant) and in its lower parts the subsolum (where the original rock structure or fabric of the bedrock is preserved) (Moragues-Quiroga et al., 2017), the pedon portions were described and subdivided according to solum and subsolum parts following the methodology of Juilleret et al. (2016). Furthermore, reduced iron was tested in the field using an alpha-alpha-dipyridyl solution (Soil Survey Staff, 2014a) and the aquic conditions were registered in situ. 
Table (2): Abbreviated geomorphic information and salient site description of the representative pedons in a catena in Wadi Al-Molak study area

\begin{tabular}{|c|c|c|c|c|c|c|c|c|c|c|c|c|c|}
\hline \multirow{2}{*}{$\begin{array}{c}\text { Period of } \\
\text { cultivation }\end{array}$} & \multirow{2}{*}{ Sampled pedons } & \multirow{2}{*}{$\begin{array}{l}\text { Pedons } \\
\text { ID }\end{array}$} & \multicolumn{3}{|c|}{ Geomorphic description } & \multicolumn{4}{|c|}{ Surface morphometry } & \multirow{2}{*}{$\begin{array}{c}\text { Soil } \\
\text { drainage }\end{array}$} & \multirow{2}{*}{$\begin{array}{l}\text { Current } \\
\text { LU/LC }\end{array}$} & \multirow{2}{*}{$\begin{array}{c}\text { Parent } \\
\text { material } \\
\text { (kind) }^{\mathrm{j}}\end{array}$} & \multirow{2}{*}{$\begin{array}{c}\text { Surface } \\
\text { frags. } \\
\text { (kind, class) }\end{array}$} \\
\hline & & & $\begin{array}{l}\text { Anthro. } \\
\text { features }\end{array}$ & $\mathrm{LS}^{\mathrm{b}}$ & $\mathrm{LF}^{\mathrm{c}}$ & Com. ${ }^{\mathrm{d}}$ & $\begin{array}{c}\text { Slope } \\
\text { position }^{\mathrm{e}}\end{array}$ & $\begin{array}{l}\text { Slope } \\
\text { gradient }^{\mathrm{f}}\end{array}$ & $\begin{array}{l}\text { Altitude } \\
\text { (m); } \text { MTL }^{\mathrm{g}}\end{array}$ & & & & \\
\hline \multirow{4}{*}{ Till 1986} & 1,2 & I & $\mathrm{RP}$ & DP & FP & DP & $\mathrm{TS}$ & 02 & $7-8$ & PD & CG & ALL & FMC \\
\hline & $3,4,5,6$ & II & ANT & DP & FO & RI & $\mathrm{TS}$ & 03 & $9-15$ & PD & $\mathrm{RC}$ & ALL & FMC \\
\hline & $8,9,10,11$ & III & RL & BJ & $\mathrm{AF}$ & $\mathrm{TR}$ & $\mathrm{TS}$ & 03 & $11-20$ & PD & $\mathrm{CV}$ & ALL & CAC \\
\hline & $13,14,15,16$ & IV & RL & AP & TER & TR & FS & 04 & $28-37$ & WD & $\mathrm{CV} \& \mathrm{CR}$ & ALL & $\mathrm{CAC}$ \\
\hline $1987-1996$ & $7,12,17,18,19,22$ & $\mathrm{~V}$ & RL & AP & TER & RI & FS & 04 & $12-60$ & MW & $\mathrm{CV} \& \mathrm{CR}$ & ALL & CAC \\
\hline $1997-2006$ & $23,26,27,28$ & VI & RL & AP & TER & RI & FS & 04 & $75-83$ & $\mathrm{VP}$ & $\mathrm{CR}$ & ALL & CAC \\
\hline 2007-2016 & 20,24 & VII & RL & AP & TER & RI & FS & 04 & $69-92$ & SP & $\mathrm{CR}$ & ALL & $\mathrm{CAC}$ \\
\hline \multirow{5}{*}{$\begin{array}{l}\text { Native desert } \\
\text { land }\end{array}$} & 21,25 & VIII & LVL & $\mathrm{AP}$ & TER & RI & FS & 04 & $81-93$ & $\mathrm{SP}$ & OS & SAL & QUA \\
\hline & $29,30,31,32$ & IX & LVL & PS & FG & MB & BS & 05 & $85-93$ & SP & OS & PED & QUA \\
\hline & $33,34,35,36$ & $\mathrm{X}$ & -- & PS & $\mathrm{PE}$ & $\mathrm{MB}$ & $\mathrm{BS}$ & 05 & $95-105$ & SP & $\mathrm{SG}$ & PED & MXR \\
\hline & $37,38,39,40,41$ & $\mathrm{XI}$ & -- & $\mathrm{MO}$ & $\mathrm{MN}$ & MF & $\mathrm{SH}$ & 06 & $107-121$ & SE & $\mathrm{SG}$ & COL & MXR \\
\hline & 42,43 & XII & -- & $\mathrm{MO}$ & $\mathrm{MN}$ & $\mathrm{FF}$ & $\mathrm{SH}$ & 07 & $129-137$ & VP & RK & RES & MXR \\
\hline
\end{tabular}

Abbreviated parameters are given as per Schoeneberger et al. (2012) and FAO (2006).

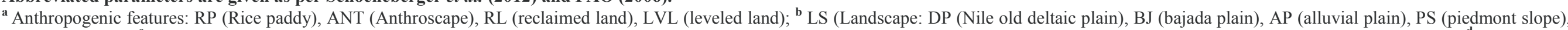

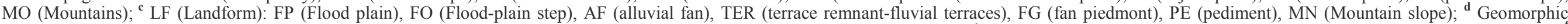

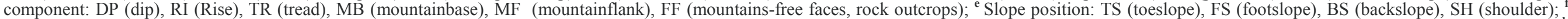

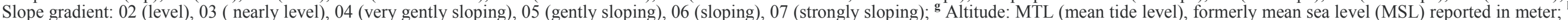

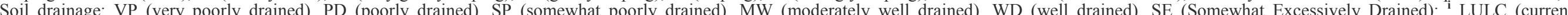

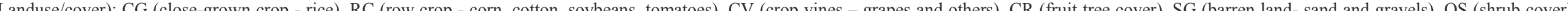

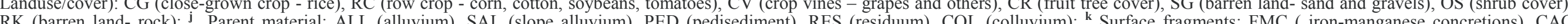
(carbonate concretions), ( QUA (Quartz), MXR (mixed rocks). 


\section{Soil property characterization}

Collected soils were air dried, sieved to isolate the fine-earth fraction $(<2 \mathrm{~mm})$, and prepared for physical (e.g., gravel content, soil texture, available water, and bulk density) and chemical (e.g., electrical conductivity $\left(\mathrm{EC}_{\mathrm{e}}\right), \mathrm{pH}$, soil organic carbon (SOC), soil total nitrogen (STN), CEC, lime, gypsum, and free iron oxides) laboratory analyses. Sample weight and volume were corrected for coarse fragment content (Soil Survey Staff, 2014b). Particle-size analyses were determined using dry sieving and the pipette method (Pansu and Gautheyrou, 2006). The USDA particle size classes, namely, coarse sand $(<2.0-1.0 \mathrm{~mm})$, medium sand $(<1.0-0.5 \mathrm{~mm})$, fine sand $(<0.5-0.05 \mathrm{~mm})$, silt $(<0.05$ $0.002 \mathrm{~mm})$, and clay $(<0.002 \mathrm{~mm})$ were used to classify the textural classes. Samples were pretreated with $\mathrm{NaOCl}$ at $\mathrm{pH} 9.5$ to remove organic matter, citratedithionite to remove free $\mathrm{Fe}$ oxides, and subsequently dispersed with dilute sodium hexametaphosphate. Soil bulk density $(\rho b)$ was determined for each horizon by the intact core method (Grossman and Reinsch, 2002). Soil electrical conductivity (ECe) of saturated extract, $\mathrm{pH}$ of saturated paste, calcium carbonate, cation exchange capacity (CEC), exchangeable sodium percentage (ESP), and available water content were determined as per the standard procedures (Soil Survey Staff, 2014b). Gypsum concentration was determined by the differential water loss method (Artieda et al., 2006). Soil organic carbon (SOC) concentration was determined by dry combustion after decarbonatation (Soil Survey Laboratory Staff, 2004). Soil total nitrogen (STN) concentration was determined by the dry combustion method at $900^{\circ} \mathrm{C}$ (Nelson and Sommers, 1996). Free iron oxides were extracted using a dithionite-citrate buffer, according to the method described by Mehra and Jackson (1960). All studied pedons were classified using USDA Soil Taxonomy (Soil Survey Staff, 2014c).

\section{Data analysis}

The geostatistical analyses of the various results were carried out using ArcGIS 10.1 (ESRI, Redlands, CA) to represent the soil attributes. The maps obtained were compiled to obtain categorical maps. Those categorical maps defined the soil homogeneous units and the soil classification map. Morphological data were only presented for the representative pedons that have the dominant characteristics for each landscape across the cultivation ages. Physical and chemical data were interpolated within each landscape. These analyses were combined across cultivation ages in the study area to create a realistic picture of the spatial distributions. All other statistics (e.g., mean and standard deviation) were analyzed for both physical and chemical data and prepared with SPSS 16.

\section{RESULTS}

\section{Land cover change in Wadi Al-Molak}

By field investigation and applying satellite images, a comparison among the cultivation periods (till 1986, 1987-1996, 1997-2006, and 2007-2016) using time series Landsat images was carried out. (Table 1 and Figs.
2, 3). The analyses of land cover change overtime indicated that the agrarian expansion projects were expanded gradually from the north at lowland position to the south at midland position (Tables 1 and 2). Agricultural land was the major cover at the end of 1986 which had an area of $225 \mathrm{~km}^{2}$, accounting for $26.5 \%$ of the total study area while the remaining area $\left(625 \mathrm{~km}^{2}\right)$ was not-used as native land (Table 1 and Figs. 2a, 3).

The cultivated area in 1986 was mainly distributed evenly across lowland and midland landscapes as $100 \%$ of Nile old deltaic plain, $78.2 \%$ of bajada plain, and $22.5 \%$ of alluvial plain (Table 1 ). The major crops cultivated till December 1986 were rice (Oryza sativa), maize (Zea mays), tomatoes (Lycopersicon esculentum), and some forage (e.g., Medicago sativa and Trifolium spp.). The rice crop was intensively cropped in the area of dipped delta (Table 2) because of the high amounts of fine soil materials deposited in the lowland (Table 4). The water used for irrigation of soils at this stage was supplied from the Nile River through Ismailia canal without water lifting devices. It has also been observed that the settlements and scattered rural built-up areas are mostly surrounded by agricultural activities. It means the area near the population has been cleared for the production of crops to fulfill the basic necessities of life.

During 1987-1996, an area of $118 \mathrm{~km}^{2}$ being native land was converted to agricultural cover by field crops and orchard which occupied on $21.8 \%$ of bajada plain, $23 \%$ of the alluvial plain, and $3.8 \%$ of piedmont slope land (Table 1 and Figs. 2b, 3). The main crops cultivated in this area were groundnut (Arachis hypogaea), wheat (Triticum aestivum), barley (Hordeum vulgare), peppers (Capsicum annuum), tomatoes (Lycopersicon esculentum), mango (Mangifera indica), guava (Psidium guajava), banana (Musa spp.), and orange (Citrus sinensis). The area of native land was slightly declined by $20.2 \%$ from 625 to $499 \mathrm{~km}^{2}$. By contrast, there had an increase in cropland $(13.9 \%$ of the total study area) which derived through the successive reclamation processes. At the end of this stage, the land cover of Wadi Al-Molak was modified to comprise $40.4 \%$ total cropland area $\left(343 \mathrm{~km}^{2}\right), 0.9 \%$ total urban area $\left(8 \mathrm{~km}^{2}\right)$, and $58.7 \%$ native land $\left(499 \mathrm{~km}^{2}\right)$ (Table 1).

Throughout the stage of 1997-2006, an area of 110 $\mathrm{km}^{2}$ of the native desert lands, situated on each of $25.5 \%$ of alluvial plain $\left(102 \mathrm{~km}^{2}\right)$ and $4.3 \%$ of piedmont slope land $\left(8 \mathrm{~km}^{2}\right)$ (Table 1 and Figs. 2c, 3) was changed into horticulture trees by mainly fruits and citrus; e.g., orange (Citrus sinensis), grapes (Vitis vinifera), mango (Mangifera indica), guava (Psidium guajava), strawberry (Fragaria spp.), banana (Musa spp.), and lemon (Citrus limon). The native desert land, therefore, was reduced by $24.9 \%$ from $499 \mathrm{~km}^{2}$ in December 1996 to $375 \mathrm{~km}^{2}$ in December 2006. Meanwhile, the total cropland area was increased through Al-Shabab agricultural projects, implemented by the government (Khalaf and Gad, 2015), by $24.3 \%$ from 343 $\mathrm{km}^{2}$ in 1996 to $453 \mathrm{~km}^{2}$ in 2006. In December 2006, the land surface of the study area was mainly covered by $53.3 \%$ total cropland, $2.6 \%$ total urban area, and $44.1 \%$ not-used desert land (native land). The area reclaimed in this period was less than that documented in 1996. 

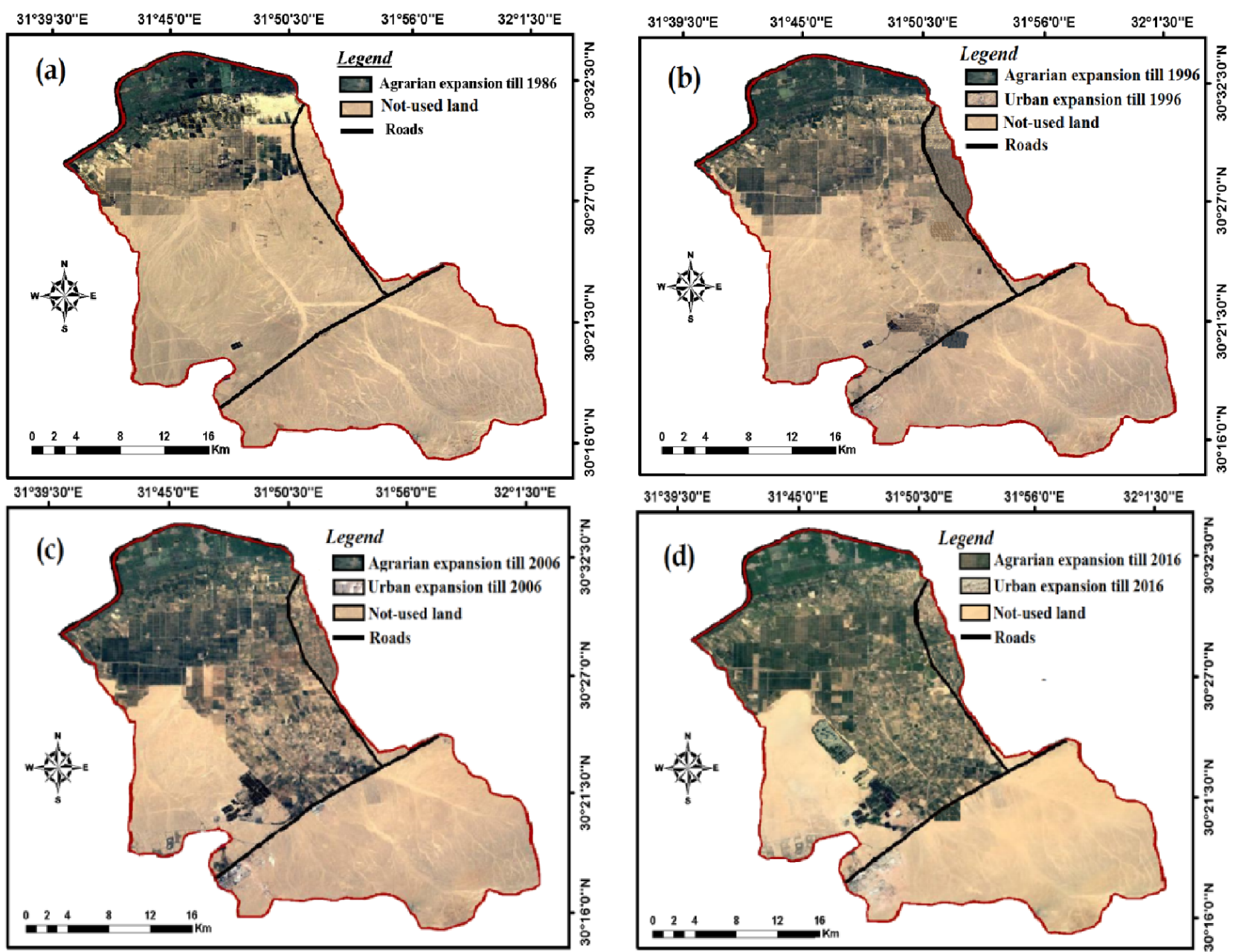

Fig. (2): Time series profiles of land cover changes for Wadi Al-Molak watershed showing expansion dynamics of agriculture, built-up land, and native desert land fractions detected at different years: (a) December 1986, (b) December 1996, (c) December 2006, and (d) December 2016

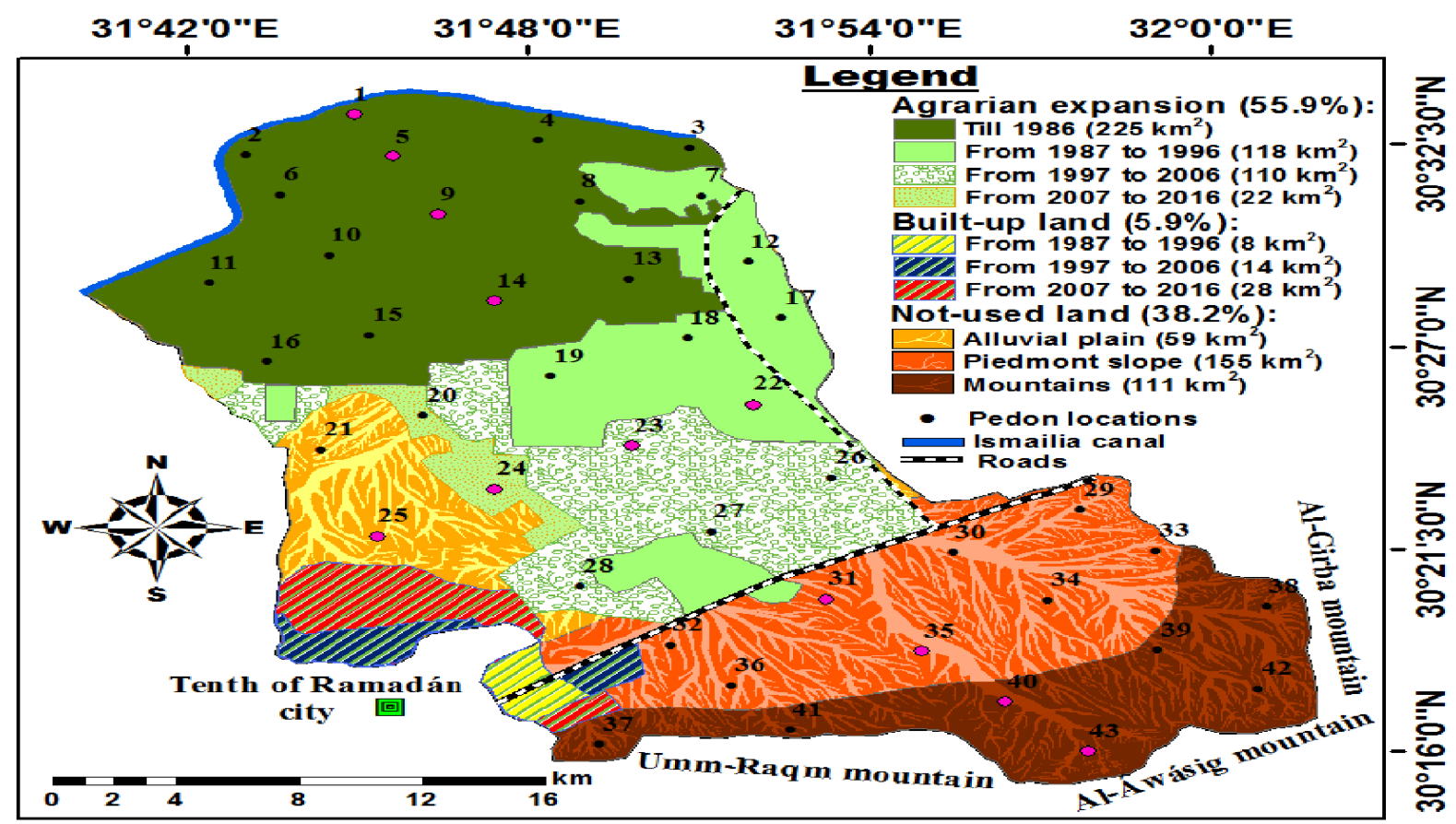

Fig. (3): Spatial distribution of expansion lands within the landscapes of the Wadi Al-Molak study area from December 1986 to December 2016 showing cultivated lands, built-up land, and native desert land. Pedon locations are distributed within the cultivated and native land. Horizontal transect on alluvial plain, indicated by pink dots, were used for comparing cultivated soils under different cultivation ages (e.g., pedons 22, 33, and 24) with native land (pedon 25) 

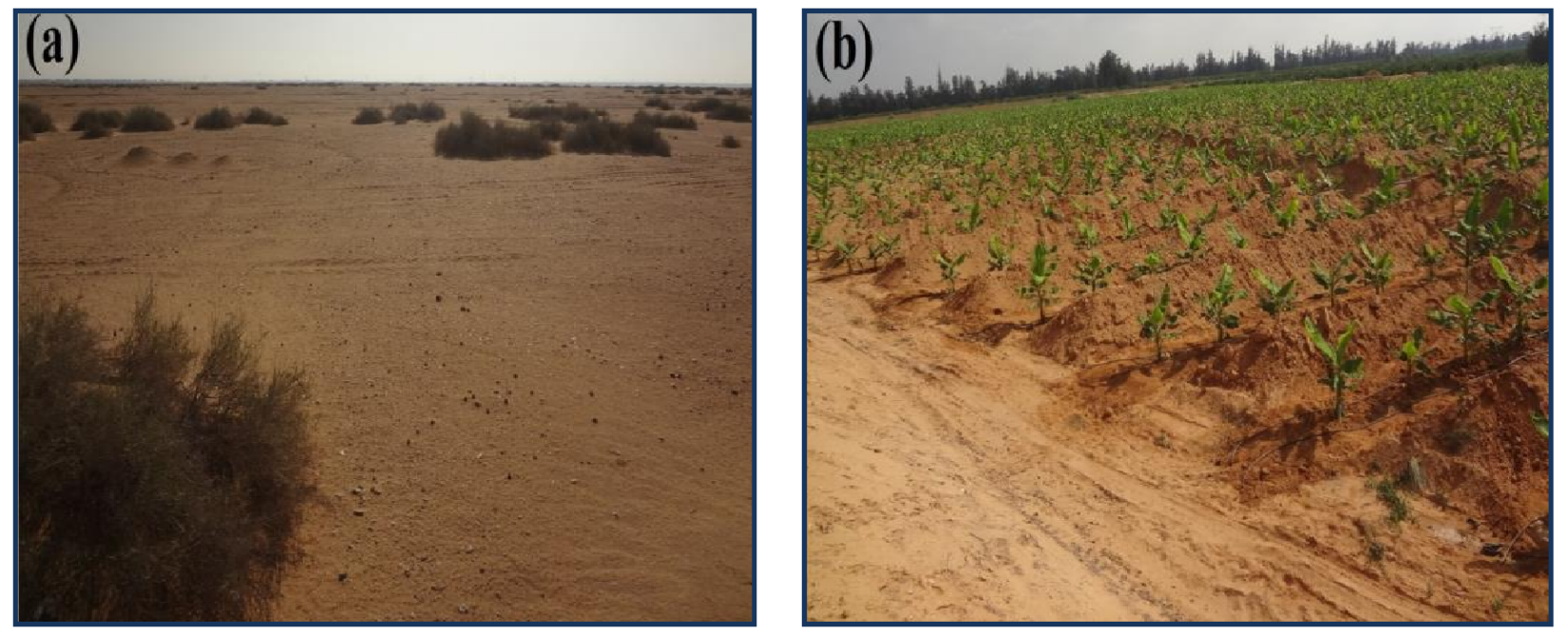

Fig. (4): Overview of landcover change within the alluvial plain landscape. (a) Left panel shows the land under natural vegetation (natural landscape) which used for comparison (e.g., pedons 21 and 25). (b) Right panel shows the land under cultivation (for example, banana) which cultivated during 2007-2016 (anthropogenic landscape).

By the end of 2016 , only $22 \mathrm{~km}^{2}$ of not-used desert lands, occupied on $5.5 \%$ of alluvial plain landscape, was replaced by cropland and cultivated mainly with fruit-citrus crops; e.g., banana (Musa spp.), mango (Mangifera indica), orange (Citrus sinensis), and lemon (Citrus limon). The satellite imageries in 2016 showed a slight increase in cropland. Therefore, the land cover of the study area in 2016 comprised $55.9 \%$ total cropland area, $5.9 \%$ total urban area, and $38.2 \%$ native land (Table 1 and Figs. 2d, 3). The area cultivated in this period was drastically less than that documented in both of 1996 and 2006. The area under horticulture increased from 1996 to 2016 due to the economic benefit to the stockholders. The irrigation water was lifted from Ismailia canal to localize the expanded agricultural areas during the periods 1987-1996, 1997 2006, and 2007-2016. Furthermore, some reclaimed lands at bajada and alluvial plains were cultivated based on the groundwater supply. The groundwater is affected by excessive pumping for irrigation and reclamation activities, which in turn resulted in the deeper saline groundwater from the Miocene aquifer (Khalil et al., 2015). To conclude, the agriculture in Wadi Al-Molak increased by $250 \mathrm{~km}^{2}$ (52.6\%) between December 1986 and December 2016 (30 years) with an annual rate of $8.3 \mathrm{~km}^{2} \mathrm{yr}^{-1}$, whereas the total urban land was established in $50 \mathrm{~km}^{2}$ and concentrated at the $10^{\text {th }}$ of Ramadan city.

\section{Soil morphology}

The major morphological properties of sites and pedons of Wadi Al-Molak are presented in Tables (2 and 3), respectively and visualized in Figs (4, 5, 6, and 7). The morphology of the cultivated soils on lowland differed from that of the native soils on upland (notcultivated landscapes) in their depth, colors, concentrations, redoximorphic features, and the absence or presence of diagnostic horizons/solum. The regolith compartments, solum horizons, and subsolum layers, were observed in the studied pedons. The solum, upper part of regolith (A+B horizons) (Juilleret et al., 2016; Moragues-Quiroga et al., 2017), was observed as the whole pedons (155-180 cm depth) in Nile old deltaic plain $(100 \%)$ (Fig. 5a, b), whereas it observed only in the upper parts of the cultivated pedons on $100 \%$ of bajada plain and $76.5 \%$ of alluvial plain at different thicknesses overlaying the regolithic layers designated with C (Figs. 5c, d and 6a, b, c). For example, the solum of 20-11 yr cultivated soils showed two horizons described as follows (Tables 3, 4 and Fig. 6b): a $35 \mathrm{~cm}$ brown (7.5YR 4/4) silt loam Ap anthropic horizon on top of a $20 \mathrm{~cm}$ brownish yellow (10YR 6/8) sandy clay loam Bw cambic horizon. By contrast, the solum was absent in the native lands on the natural landscapes ( $14.8 \%$ of alluvial plain, $83.8 \%$ of piedmont slope, and $100 \%$ mountains) (Table 1), whereas the subsolum layers; e.g., regolithic layer $(\mathrm{C})$, saprolithic $(\mathrm{Cr})$, and paralithic layers (R), defined by Juilleret et al., 2016 and Moragues-Quiroga et al., 2017, were noticed at different depths (Figs. 6d and 7). With the exception of Nile old deltaic plain pedons, the regolithic layers (C) were observed in the deeper layers of the cultivated pedons on bajada and alluvial plains, whereas they found as the whole pedons under natural vegetation on the piedmont slope and mountains landscapes. Furthermore, saprolithic $(\mathrm{Cr})$, and paralithic layers $(\mathrm{R})$ were only noticed in the mountains pedons (Fig. 7d). They were represented by a very pale brown (10YR 8/2) sand C layer, and light gray (10YR 7/2) sandy Cr layer.

The soil color of all pedons was widely varied from 7.5YR to 10YR in hue, 2 to 8 in value, and 1 to 8 in chroma (Table 2). The soil color of Nile old deltaic plain ranged from black (10YR 2/1) at the surface horizons to grayish brown (10YR 5/2) at the deeper horizons (Fig. 5a, b). The E horizon was gray $10 \mathrm{YR}$ $(5 / 1)$ (Fig. 5b). Meanwhile, the color of the surface horizons in alluvial plain soils was brown (7.5YR 4/2, $4 / 4$ ) under $21-\geq 30 \mathrm{yr}$ of cultivation, brownish yellow (10YR 6/6) under $\leq 10$ yr of cultivation, and very pale brown (10YR 8/3) in the native soils (Fig. 6a, b, c). By contrast, soils of other not-cultivated landscapes (e.g., mountains and piedmont slope) had lighter colors and varied from light gray (10YR 7/2) to brownish yellow 
(10YR 6/8) (Fig. 7). In the cultivated soils on alluvial plain (e.g., pedons 22, 23, and 25), an abrupt change from the top to the bottom in their dominant color, from brown $(7.54 / 2)$ to yellow (10YR 8/6), were observed, and was the buried by discontinuous soil horizons $(\mathrm{Ab})$ deriving from fine products of Nile old delta during flooding processes. The $\mathrm{Ab}$ horizon has been buried beneath more recent coarse deposits came from upland (e.g., mountains and piedmont slope). Ap is an epipedon horizon which is disturbed surface horizon by cultivation. This horizon is where most root activity occurs and generally is the most productive layer of soil.

There was a considerable variation in grade, size, and the shape of soil structure characteristics within each pedon and among cultivation periods. The cultivated pedons at lowland exhibited a moderate fine subangular blocky and weak medium granular structure in the Ap soil horizon and from moderate medium angular blocky to the weak medium prismatic structure in the Bt soil horizons, and consistence from firm to extremely firm when moist. The cultivated pedons occurred on alluvial plain (e.g., pedons 14, 22, 23, and 24) exhibited weak to moderate granular structure in the Ap soil horizon and from granular to massive structure in the Bw soil horizons, and consistence from loose to firm when moist. By contrast, the native land on upland (e.g., mountains and piedmont slope) exhibited structureless units (e.g., single grain or massive) throughout the pedon layers and consistence from nonsticky to slightly sticky and nonplastic to slightly plastic when wet (Table 2 and Fig. 7).

Clay coatings were generally more strongly extensive in the irrigated pedons. Under $>30 \mathrm{yr}$ of cultivation, clay films began at a depth of $20 \mathrm{~cm}$ in the dipped delta plain (Fig. 5a) versus $75 \mathrm{~cm}$ in the raised delta plain (Fig. 5b), compared with the $\leq 10-20$ yr irrigated pedons and dry pedons in the not-cultivated soils at upper slopes (Tables 2, 3 and Fig. 5). For example, in the irrigated pedons, clay films were described in the third horizon, which extended from 20 to $43 \mathrm{~cm}$ (Fig. 5a), and were described as common, clay films, located on all faces on peds and between sand grains (Table 3 ). Since clay films were observed, and there was a perceptible increase in clay content, the horizon was designated as $\mathrm{Bt}$ in the $>30-\mathrm{yr}$ cultivated pedons. Common redoximorphic features, as an indication of the presence of periodic saturation of upper parts of pedon, were observed as Ferriargillans or manganese films in the delta soils studied. Iron was oxidized mostly on the surfaces of slickensides that were dominantly dark reddish brown (7.5YR 3/2) (Table 2 and Fig. 5a). In contrast, no clay films were observed at nearly equal depths in the $\leq 10-20 \mathrm{yr}$ cultivated soils. Therefore, the cambic horizon $(\mathrm{Bw})$ was formed which is an altered horizon and weakly developed. Masses of $\mathrm{Fe}$ or $\mathrm{Mn}$ and redox features were common in the cultivated soils across different ages compared with the not-cultivated soils.

\section{Soil physical properties}

Gravel, fine-earth fractions, soil available water (A.W.), and bulk density ( $\rho b)$ are presented in Table (4).
The gravel content increased significantly in the mountains pedons (ID. XI and XII) and ranged from $215 \mathrm{~g} \mathrm{~kg}^{-1}$ to $551 \mathrm{~g} \mathrm{~kg}^{-1}$ for the respective $\mathrm{C}$ and $\mathrm{Cr}$ layers (Table 4 and Fig. 7c, d). The abrupt increase and the change in the size of rock fragments between $2 \mathrm{C}$ and $3 \mathrm{Cr}$ layers evidenced a lithologic discontinuity. The mountains and piedmont slope landscapes had a gravel content ranging from $92 \mathrm{~g} \mathrm{~kg}^{-1}$ in the Ckm layers of fan piedmont landform (Table 4 and Fig. 7a) to $551 \mathrm{~g} \mathrm{~kg}^{-1}$ in the $3 \mathrm{Cr}$ layers of mountainflank landform (Table 4 and Fig. 7c). In comparison, the midland (alluvial plain) had a gravel content ranging from $15 \mathrm{~g} \mathrm{~kg}^{-1}$ in Ap horizon of the soils under $>30 \mathrm{yr}$ of cultivation (Fig. $5 \mathrm{~d}$ ) to $155 \mathrm{~g}$ $\mathrm{kg}^{-1}$ in $\mathrm{C} 2$ layer of the soils under native vegetation (Table 4 and Fig. 6d). In contrast, the cultivated soils at lowland (e.g., Nile old deltaic plain and bajada plain) had lower values of gravel content (0.0-19 $\left.\mathrm{g} \mathrm{kg}^{-1}\right)$ compared with cultivated soils on alluvial plain (Table 4 and Fig. 5).

Soils across all landscapes showed differences in particle size distribution. Clay was the most abundant textural class occurred in the Nile old deltaic plain soils, followed by silty clay loam in the surface horizons and loam in the deeper horizons of bajada plain pedons (Table 4). All upper soil horizons in the cultivated soils significantly increased in clay fraction with increasing age of cultivation. Whereas clay concentration in the surface horizons of cultivated soils were $199 \mathrm{~g} \mathrm{~kg}^{-1}$ under $\leq 10$ yr of cultivation (Table 4; Pedons ID. VII), $211 \mathrm{~g} \mathrm{~kg}^{-1}$ under 20-11 yr of cultivation (Table 4; Pedons ID. VI), $331 \mathrm{~g} \mathrm{~kg}^{-1}$ under 30-21 yr of cultivation (Table 4; Pedons ID. V), and from 337 to $519 \mathrm{~g} \mathrm{~kg}^{-1}$ under $>30 \mathrm{yr}$ of cultivation (Table 4; Pedons ID. I, II, III, IV). By contrast, clay fraction within pedons of mountains and piedmont slope was similarly low at 16 and $77 \mathrm{~g} \mathrm{~kg}^{-1}$, respectively, (Table 4) compared with those of the lowland soils $\left(634 \mathrm{~g} \mathrm{~kg}^{-1}\right)$ (Table 4; Pedons ID. I). Meanwhile, sand-sized particles dominated the fine-earth fractions across upper landscapes, with a general decrease in sand content with decreasing elevation.

Soil bulk density ( $\rho b)$ values of $>30 \mathrm{yr}$ cultivated soils were irregularly varied from $1.17 \mathrm{~g} \mathrm{~cm}^{3}$ in the surface horizons to $1.54 \mathrm{~g} \mathrm{~cm}^{3}$ in the subsoil layers (Table 4). While lower values were detected in $\leq 10$ yr cultivated soil $\left(0.98-1.27 \mathrm{~g} \mathrm{~cm}^{3}\right), 20-11 \mathrm{yr}$ cultivated soil (1.01-1.29 $\left.\mathrm{g} \mathrm{cm}^{3}\right)$, and $30-21 \mathrm{yr}$ cultivated soil $\left(0.95-1.31 \mathrm{~g} \mathrm{~cm}^{3}\right)$ (Table 4). In contrast, the soil $\rho b$ values increased with increase in depth for the not-cultivated soils at upland partly because of the decrease in SOC and clay concentrations.

Soil available water values increased with decreasing elevation across the toposequence and showed mean values between $35.7-57.2 \%$ in Nile old deltaic plain, $10.5-25.1 \%$ in bajada plain, $5.5-29.7 \%$ in alluvial plain under cultivation, compared with the notcultivated landscapes (3.2-13.2\%) (Table 4). The highest values of A.W. were in the lowland soils under all land uses, which may be attributed to the high concentrations of clay and organic carbon. 

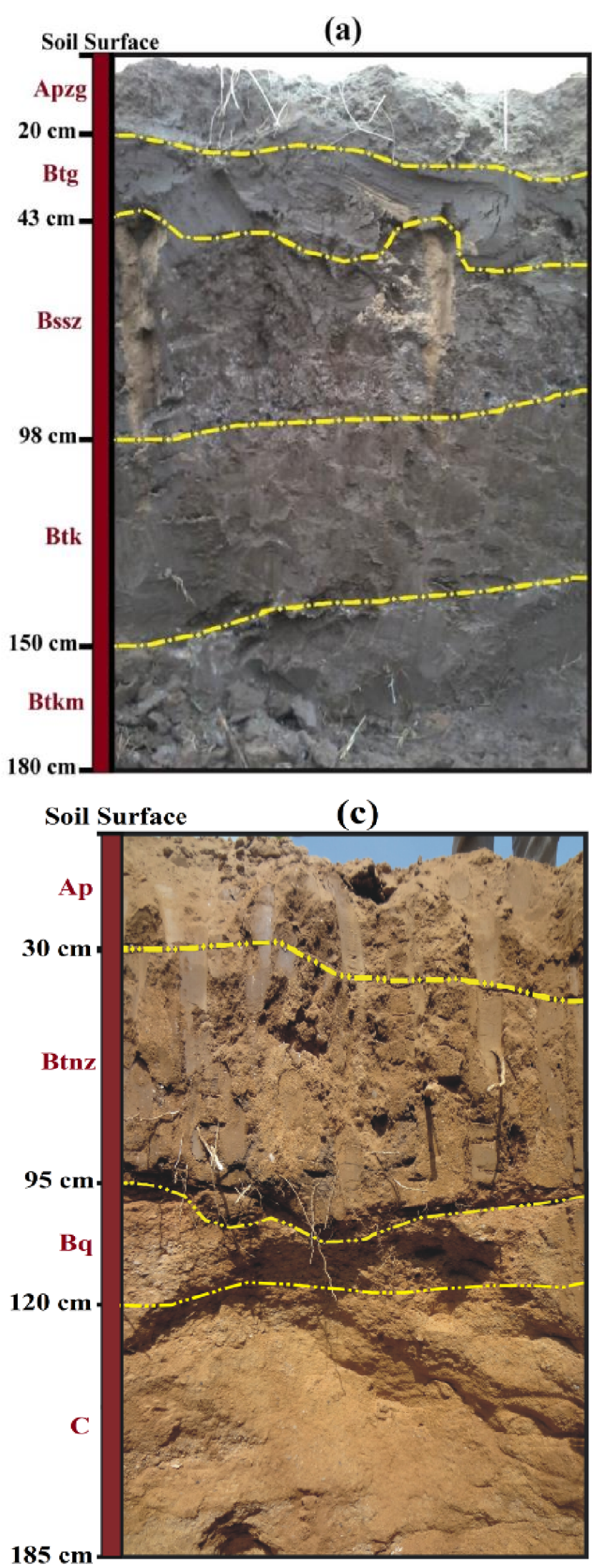
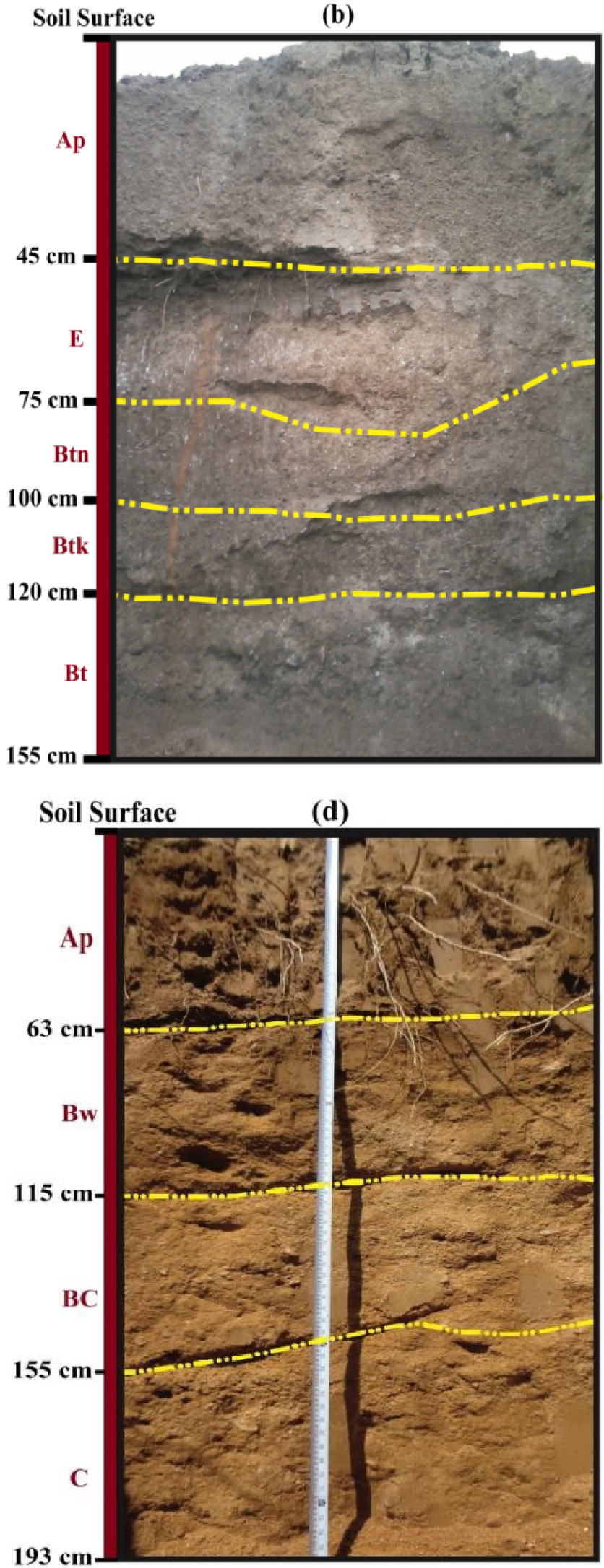

Fig. (5): Polygenetic reference pedons with different horizon sequences formed under more than 30 years of cultivation, detected by December 1986, at different landscapes: (a) dipped delta at Nile old deltaic plain landscape cultivated mainly with rice under flood irrigation, (b) raised delta at Nile old deltaic plain landscape cultivated mainly with vegetables under flood irrigation, (c) bajada plain landscape cultivated with grapes under drip irrigation, and (d) alluvial plain landscape cultivated with orange under drip irrigation. 


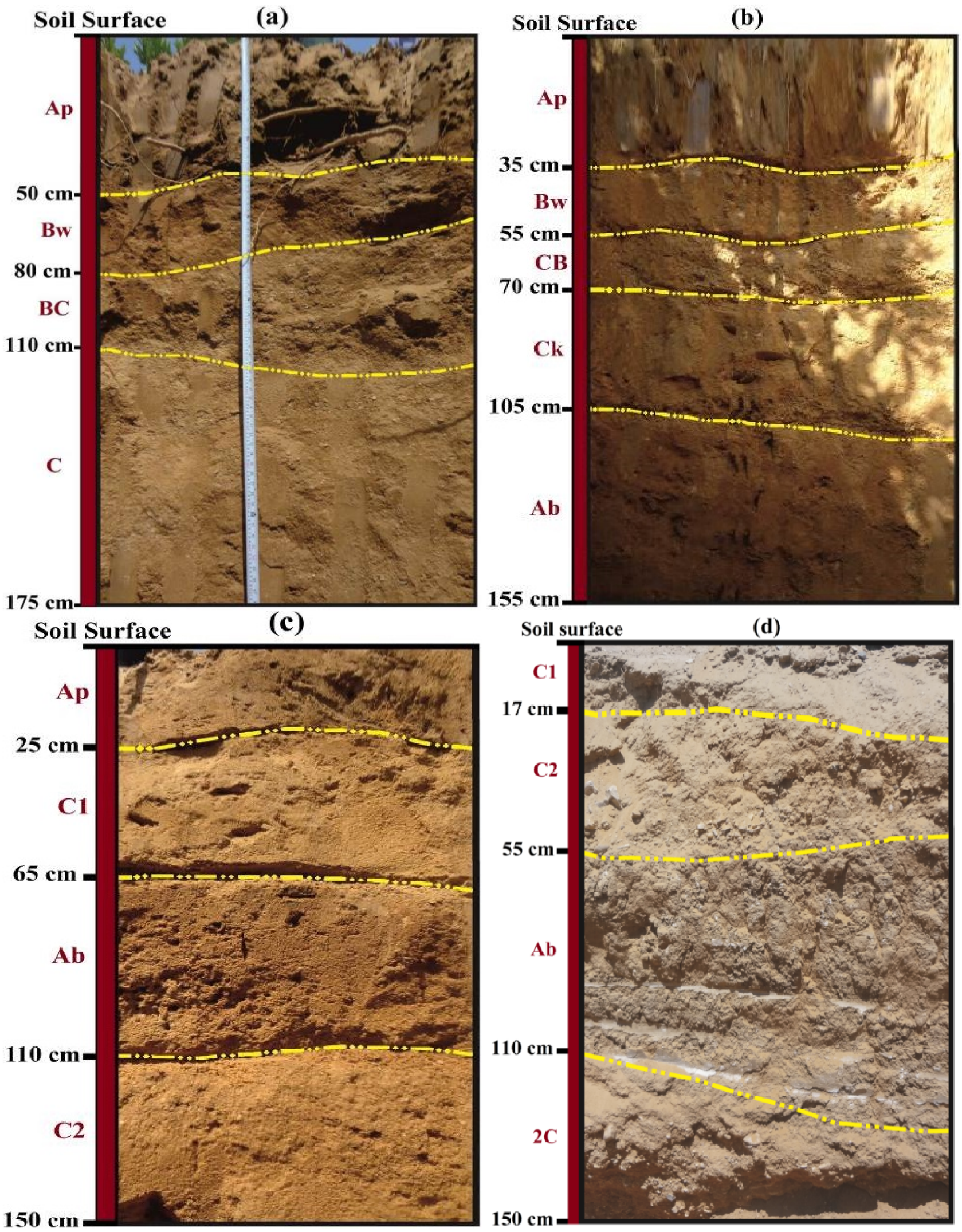

Fig. (6): Comparison of whole reference pedons occurred on the alluvial plain for cropland under different periods and native land. (a) 30-21 yr of cultivation (cultivated within the period from January 1987 to December 1996), (b) 20-11 yr of cultivation (cultivated within the period from January 1997 to December 2006), (c) $\leq 10$ yr soil cultivated within the period from January 2007 to December 2016, and (d) reference native land (not-cultivated) as reference point from which the comparison with cultivated soil processed. Buried soils $(\mathrm{Ab})$ were only observed in the alluvial plain landscape at different depths for both cultivated and native pedons as a result of erosion and deposition processes sequence. 

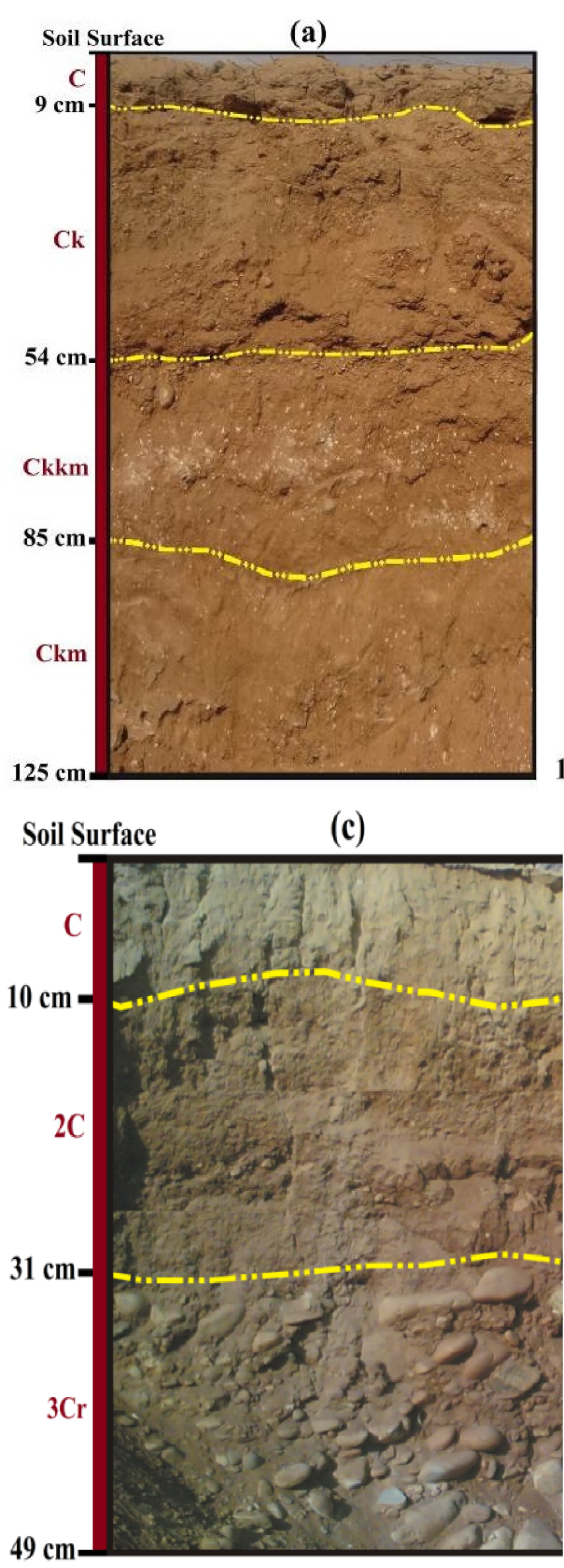

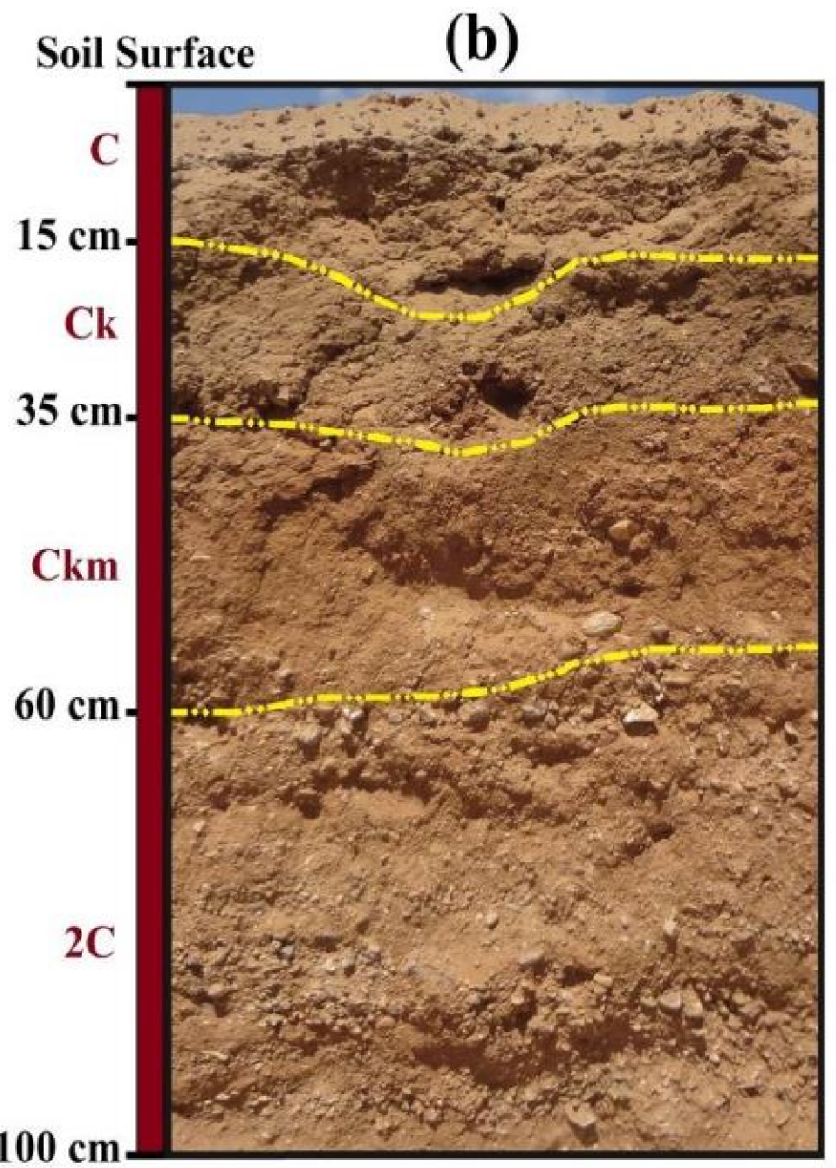

$100 \mathrm{~cm}$

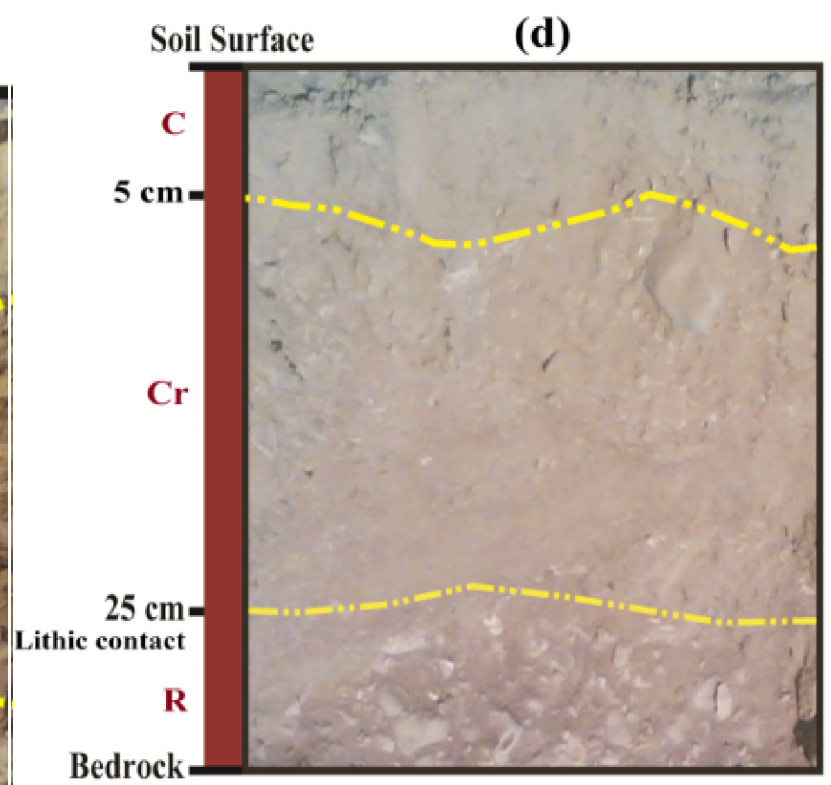

Bedrock

Fig. (7): Native upland pedon photographs for the (a) fan piedmont landform at piedmont slope landscape, (b) pediment landform at piedmont slope landscape, (c) mountainflank at mountains landscape, and (d) mountains-free faces at mountains landscape. These pedons were also compared with the cultivated pedons at landscape positions. 


\section{Soil chemical properties}

The results of chemical analyses conducted on soils of Wadi Al-Molak are listed in Table (5). The pattern of salinity within the pedon across the study area is related to landscape distribution and cultivation age. According to Soil Science Division Staff, (2017), EC values were highest for the lowland cultivated soils (e.g., Nile old deltaic plain and bajada plain), ranging from $5.7 \mathrm{dS} \mathrm{m}^{-1}$ (slightly saline) in bajada plain to 31.2 $\mathrm{dS} \mathrm{m}^{-1}$ (strongly saline) in dipped delta under rice cultivation. The salinity distribution within solum horizons in the alluvial plain landscape follows a conspicuous decreasing trend from moderately saline (9.1-10.9 $\mathrm{dS} \mathrm{m} \mathrm{m}^{-1}$ ) in the 30-21 yr cultivated soils to nonsaline pedons in the native soils (Table 5).

Consistent with Soil Science Division Staff (2017), pH is alkaline across all studied pedons which varied from 7.4 (slightly alkaline) to 9 (strongly alkaline). It increased downslope where the strongly alkaline soils (8.6-9) were found in Nile old deltaic plain landscape. The vertical distribution of the $\mathrm{pH}$ within each pedon may vary among landscape positions and may either decrease or increase with an increase in depth. Within all cultivated pedons, the $\mathrm{pH}$ irregularly decreased with increase in depth as a result of the longterm chemical fertilizer under extensive irrigation which is related to anthropogenic impacts. The ESP values were consistent with the $\mathrm{pH}$ values in lowland soils. They widely ranged from $8.1 \%$ at upland to $19.2 \%$ at lowland.

According to FAO (2006), the results showed an extremely calcareous character in all native pedons of mountains and piedmont slope with mean values of $\mathrm{CaCO}_{3}$ ranging from $25.1 \%$ to $36.1 \%$ (Table 5). The $\mathrm{CaCO}_{3}$ values were consistent with the $\mathrm{pH}$ values in upland soils. The maximum value was recorded in the $\mathrm{Cr}$ layer of mountain-free faces pedons whereas the lowest was registered in $\mathrm{C}$ horizon of fan piedmont. In addition, the not-cultivated soils on alluvial plain had a strongly calcareous character (20.9-25\%). By contrast, the cultivated soils on alluvial plain showed a general decreasing trend in $\mathrm{CaCO}_{3}$ content from $19.1 \%$ in the $\leq 10 \mathrm{yr}$ cultivated soil to $7.2 \%$ in the $>30 \mathrm{yr}$ cultivated the soil. Nevertheless, the reverse trend was observed in the cultivated soils on lowland: Nile old deltaic plain had a lower concentration of lime (3.5-8.4\%) than bajada plain (7.5-9.2\%).

SOC concentration varies horizontally across the landscape, and vertically within the pedon. It increased strongly downslope and with pedon depth, which is attributed to the cultivation activities at the lowland. In addition, deposition of eroded sediments (organic and inorganic) from the upland and their deposition at the lowland caused by slope position may partly play an important role in this trend. The lowest SOC concentration $(0.01 \%)$ was observed in the mountainfree faces at the shoulder and the highest $(0.82 \%)$ in the raised delta at toeslope position (Table 5).

STN concentration varies across the toposequence from the upland to the lowland. The distribution of STN in the cultivated soils followed the same trend as that of SOC, and it increased from $0.12 \%$ in the surface horizon of the pedons on the alluvial plain landscape to $0.51 \%$ in the surface horizon of the pedons of Nile old deltaic plain landscape (Table 5). By contrast, the STN concentration didn't exceed $0.10 \%$ in the surface horizons of the native soils on other landscapes. The drastic increase may be largely ascribed to the anthropogenic impact like manuring during cultivation ages. CEC values were highly concomitant with SOC and STN horizontally across toposequences and vertically within pedons. For example, values of CEC increased downslope from $3.1 \mathrm{cmol}(+) \mathrm{kg}^{-1}$ in the native upland to $60.5 \mathrm{cmol}(+) \mathrm{kg}^{-1}$ in the cultivated lowland. The CEC values indicate high fertility potential in soil at lowland compared with that of upland.

Gypsum concentration across all studied pedons was low $(0.0-2.2 \%)$. Free iron oxide values were irregularly distributed vertically throughout the pedons and horizontally across the landscapes. The pedogenic free iron content $\left(\mathrm{Fe}_{2} \mathrm{O}_{3}\right)$ is typically highest (63-7.8\%) in the Bt horizons (e.g., Btg, Btk, Btkm, and Btn) in the cultivated soils at Nile old deltaic plain, compared to the $\mathrm{Bw}$ horizons of cultivated soils $(3.8-4.8 \%)$ on the alluvial plain. In contrast, the geologic $\mathrm{Fe}_{2} \mathrm{O}_{3}$ content ranged from 1.1 to $3.3 \%$ in the not-cultivated soils at upland and described as mottles which didn't indicate existing redox conditions.

\section{Soil taxonomy}

Based on the geomorphic information (Table 2), abbreviated field descriptions (Table 3 ), and various soil properties (Tables 4 and 5), the soils were classified according to the Soil Taxonomy of Soil Survey Staff (2014c) (Table 6 and Fig. 8). The spatial distribution of soil taxonomic classification across the study area varied with age of cultivation (anthropogenic impact) and landscape position (natural impact). Cultivated soils ( $\leq 10$ to $>30$ years of cultivation) within different landscapes were classified as Vertisols $(2.8 \%$ of total study area) or Aridisols (53.1\%), while the native soils of piedmont slope and mountains at upland were keyed as Entisols (38.6\%) (Table 6). Pedons situated on dipped delta were showed slickensides in a layer $55 \mathrm{~cm}$ thick, within $100 \mathrm{~cm}$ of the mineral soil surface (Fig. 5a). These soils also had a mean value of more than 300 $\mathrm{g} \mathrm{kg}^{-1}$ clay in the fine-earth fraction either between an Ap horizon or at a depth of $50 \mathrm{~cm}$ from the surface. Furthermore, cracks of greater than $1 \mathrm{~cm}$ width, which remained open and close periodically, were developed to a depth of about $90 \mathrm{~cm}$ and absence of lithic or paralithic contact, duripan, petrocalcic horizon within $50 \mathrm{~cm}$ from the surface. The cracks were filled mainly by sand from the soil surface (Fig. 5a). Accordingly, these soils were keyed out as Vertisols order. These are dark-colored soils (Table 2) and rich in swelling clays. They were generally choked up by clays resulting from weathering, or lateral additions from neighboring slopes (e.g., Nile River or Wadi depositions). Remarkably, Vertisols occurred only in the $35.8 \%$ of Nile old deltaic plain soils with the classification of Aquic Salitorrerts and the remaining area (64.2\%) were keyed as Aridisols with the classification of Petronodic Natrargids 
cultivated in 1986 or earlier. All bajada plain pedons were classified as Aridisols (81.6\% Calcic Haplosalids and $18.4 \%$ Sodic Haplocalcids). The taxonomic classification for alluvial plain soils differed by age of cultivation, where the cultivated soil within 1987-1996 was also classified as Sodic Haplocalcids (45.5\%), the soil cultivated within 1997-2006 was classified as Anthropic Haplocambids, and the soil cultivated within 2007-2016 was classified as Typic Haplocambids. Accordingly, Sodic Haplocalcids occurred within two periods of cultivation (30-21 and $>30 \mathrm{yr}$ ) on the alluvial plain landscape. In comparison, little taxonomic variation was observed across the native soils at highelevation sites. Since $38.6 \%$ of total study area soils, situated on mountains and piedmont slope, did not generally exhibit any diagnostic horizons, and therefore classified as Entisols. The pedons of mountains were generally $<50 \mathrm{~cm}$ to the rock contact and contained $>35$ $\mathrm{g} \mathrm{kg}^{-1}$ rock fragments (Table 6). Much of the bedrock in the mountains-free faces couldn't penetrate by roots with any horizontal spacing which classified as lithic material. By contrast, soils of mountainbase landforms (e.g., pediment and fan piedmont) had the lowest frequency of lithic contacts within $100 \mathrm{~cm}$ of the soil surface, and the weathered bedrocks, classified into hard fractured bedrock, saprock, and saprolite, were penetrated by roots with horizontal spacing $<10 \mathrm{~cm}$ (Table 6). This penetration frequency prevented more of the bedrock from being classified as lithic or paralithic material (Hirmas and Graham, 2011). The taxonomic classification of Entisols was distributed evenly across the upland soils which differed by geomorphic component and landform (Tables 1 and 6). For example, the soils of mountains-free faces and mountainflank were both classified as Lithic Torriorthents $(100 \%$ of mountains) and the pediment as Typic Torriorthents (49.2\% of piedmont slope) while the fan piedmont (36.2\% of piedmont slope) and $14.8 \%$ of the alluvial plain were both Typic Torripsamments.

\section{DISCUSSION}

Because soils comprise the dynamic, vibrant skin of the Earth's terrestrial surface, people have always interacted with soils and the course of their formation. Jenny's (1941) five soil-forming factors account for most of the differences in soil chemistry and morphology across the Wadi Al-Molak toposequence. These five factors are: (1) parent material, (2) climate, (3) topography, (4) time, and (5) organisms. Anthropogenic impacts on soil properties are included in the final factor, as humans have a profound influence on many facets of soil characters. People have impacted the landscapes and soils of Wadi Al-Molak in a multitude of ways and extents, through activities, such as changes in land use and land cover, agriculture, and urbanization. Although soils are subject to major change and even destruction by natural forces on the scale of geologic time, changes resulting from human activity in Wadi Al-Molak occurred on a much shorter time scale. In some cases, human activities enhance soils for particular uses. However, in a number of cases, the interplay between humans and soils has resulted in soil degradation, which is fundamentally a negative process of formation (Khresat et al., 2008).

Cultivated soils of Wadi Al-Molak were subject to some degree of direct or indirect human disturbance. Some human activities have clear direct impacts. These include land use change, land and water management, and soil degradation (Indorante et al., 2014). Soils were also subject to indirect impacts arising from human activity, such as changing the relief by leveling and terracing (for example, cultivated lowland and midland anthropogenic landscapes were changed from original form), changing the natural soil-forming processes (e.g., pedon horizonation change), and changing the moisture regime through flood irrigation (e.g., anthraquic condition in rice paddies at lowland). All of these changes are discussed hereafter.

\section{Rapid agricultural conversion in Wadi Al-Molak}

Landscapes and soils in Wadi Al-Molak have been altered by either local people or the government to provide food and fiber. Northern lands of Wadi AlMolak (Nile old deltaic plain) were first cleared by local people for production agriculture in the early 1950s (Khalifa and Mohamed, 2008). This study presented the spatiotemporal trajectories and patterns of agricultural and urban land expansions and revealed notable differences between the studied three decadal periods (1987-1996, 1997-2006, and 2007-2016). These differences are related to landscape positions and availability of irrigation water. On the decadal scale, the annual rate of agricultural expansion decelerated from $11.8 \mathrm{~km}^{2} \mathrm{yr}^{-1}$ in the 1996 passing $11 \mathrm{~km}^{2} \mathrm{yr}^{-1}$ in 2006 to $2.2 \mathrm{~km}^{2} \mathrm{yr}^{-1}$ in 2016 (Table 1). The annual reclamation rate during 1987-1996 was the highest and decreased during 1997-2006, and then extremely declined in 2007-2016. This can be attributed to the soil limitations in the upper landscapes (e.g., piedmont slopes and mountains) and difficulties inconveniences of irrigation water. Meanwhile, some agricultural projects were implemented by the government and expanded in most soils of the alluvial plain landscape which may be attributed to the high land and water potentialities. In contrast, the expansion rate of urban land increased in uplands even more dramatically, from $0.8 \mathrm{~km}^{2} \mathrm{yr}^{-1}$ in the 1996 to $1.4 \mathrm{~km}^{2} \mathrm{yr}^{-1}$ in 2006 , and peaked in $2016(2.5$ $\mathrm{km}^{2} \mathrm{yr}^{-1}$ ) (Table 1). In comparison, the urban and industrial lands, which identified in Tenth of Ramadan city, (Fig. 3) experienced an accelerated expansion in 2016 than 2006 which can be attributed to infrastructure construction availability (e.g., high-speed freeways such as Cairo-Ismailia desert road) and soil restrictions to crop production at this area (Kuang et al., 2016). The results showed that the annual rate of urbanization (2.5 $\mathrm{km}^{2} \mathrm{yr}^{-1}$ ) is approximately equal to the rate of agrarian expansion $\left(2.2 \mathrm{~km}^{2} \mathrm{yr}^{-1}\right)$ in 2016 (Table 1). The urban changes may be associated with population growth as well as urban development during this period (Hassan et al., 2016). In the lower landscapes (e.g., Nile old deltaic plain and bajada plain), the expansion area of agricultural lands was faster in the 1986 or earlier (225 $\left.\mathrm{km}^{2}\right)$ than in 1987-1996 $\left(118 \mathrm{~km}^{2}\right)$. 
The rapid expansion was related to different driving forces of agricultural and urban expansions; e.g., availability of irrigation water, soil potentialities, national policies, and socioeconomic factors. The main sources of irrigation water in Wadi Al-Molak are Ismailia canal sourced directly from Nile River and groundwater. Access to irrigation water from either aquifers or surface water is the most important factor in crop production in the alluvial plain landscape. The alluvial plain is an extremely important center of agricultural production across the cultivation stages, whereas the agricultural development, over different periods, occurred in this plain.

The water level in Ismailia canal ranges across the study area from $17 \mathrm{~m}$ at the western part to $9 \mathrm{~m}$ above sea level at the eastern part. The altitudes of land that were cultivated in 1986 or earlier are lower than the water level in the Ismailia canal, and therefore the soils were irrigated easily from the canal without lifting processes. Current research shows that the intensively cropping in this period lands (i.e., Nile old deltaic plain and bajada plain) were mainly a result of deep and inherent soil fertility as well as the availability of surface water from the Nile. Additionally, the population growth and socioeconomic variables were the prime driving forces for developing this area in 1986. Meanwhile, the soils of midland and upland of Wadi Al-Molak (i.e., alluvial plain and piedmont slope) are at higher elevations than the level Ismailia canal water, and therefore the irrigation water was lifted to soils under cultivation over the past three decades (1987-1996, 1997-2006, and 2007-2016) (Fig. 3). Due to the huge budgets for the lifting of irrigation water, the government and investors were intervened to develop these areas on a national scale (Kuang et al., 2016). Although the native lands on alluvial plain $\left(59 \mathrm{~km}^{2}\right)$ (Table 1) are deep productive soils (Tables 4 and 5), they are still under natural vegetation (Fig. 4) because of the national development strategies of the country. Hence, the national policies have stronger influences on agricultural expansion than socioeconomic factors over the past 30 years.

\section{Impacts on soil physical change}

As agricultural development progressed, desert lands of Wadi Al-Molak were plowed for cropland uses. While using soils for cropland caused multiple disturbances to soil functions through the intensive irrigation, the most direct impacts come from physical disruption. Thus, irrigation affected the particle size distribution by increasing clay movement within the pedon, and by possibly increasing mineral weathering to produce a greater quantity of layer silicates as proposed in a similar comparison of irrigated and dryland soils in Kansas by Presley et al. (2004). For example, the higher clay concentrations in the subsurface horizons (e.g., Bt, $\mathrm{Btg}, \mathrm{Btn}$, and Btk) than in the surface horizons (e.g., Ap and Apzg) may indicate possible clay translocation from the surface horizon to the horizon below. Some deepest layers of both cultivated soils and native soils on alluvial plain contained buried $\mathrm{Ab}$ horizons deriving from products of Nile delta during flooding and deposition (Fig. 6b, c, d). These horizons showed an abrupt change in textural classes from sandy loam or loamy sand to sandy clay loam or o clay loam, respectively, indicated a lithologically discontinuous soil. The increase in variation was probably caused by the increased complexity of geomorphic (natural impact) and pedogenic processes (anthropogenic impact).

Tillage as an agricultural practice occurred in lowland soils leads to changes in mechanical impedance, which can be described in terms of soil bulk density. Tillage changes the physical arrangement of soil particles vertically within studied pedons, which has cascading effects on physical properties (Wilson et al., 2013). In soil at the alluvial plain, low bulk density reached to $0.98 \mathrm{~g} \mathrm{~cm}^{3}$, (Table 3) indicates a low level of soil compactness under no-till fruit production and, therefore, associated improvement in root penetration, and favorable root activity. By contrast, flooded rice paddies soil was subject to the use of heavy machinery and consequent soil compaction. Consequently, bulk densities were elevated in lowland compared with the crops and fruits cultivated in 1996 at midland (Table 4). Bulk density value in the surface layers of cropped bajada plain reached to $1.45 \mathrm{Mg} \mathrm{m}^{-3}$, which was the critical bulk density for wheat and other major field crops (Wilson et al., 2013). At the critical bulk density, mechanical impedance and oxygen availability are both restrictive for root growth. Although the relatively high concentration of SOC and clay in the lowland soils, these soils had higher bulk density values above thresholds (Reichert et al., 2009) compared to cultivated soils at alluvial plain. The high concentrations of clay and lime in wetlands increased the bulk density of farmed lowland (Ozpinar et al., 2018). High bulk density in lowland due to mechanized tillage practices is an indicator of low soil porosity and soil compaction as showed in subsolum horizons of lowland pedons. This impacted root growth and movement of air and water through the soil (Ozpinar et al., 2018). To conclude, compaction caused by wet soil-tillage increased bulk density and reduced crop yields (Reichert et al., 2009).

\section{Impacts on soil chemistry change}

Intensifying management practices such as fertilization, irrigation, and tillage can have negative environmental impacts (Chirinda et al., 2014). Nutrient inputs are needed to sustain soil fertility and to supply the nutrient needs of higher yielding crop production (Tugel et al., 2005). But the over-use of chemical fertilizers, intensive nutrient input, and saline groundwater occurred in lowland have been shown to be a major cause of soil degradation (Chirinda et al., 2014). Accordingly, the salinity-alkalinity problem was the major degradation process in lowland soils. The high salinity values (Table 5 and Fig. 5a) in the dipped delta plain soils at lowland would not be recommended for rice cultivation according to Ayers and Westcot (1985), who concluded that an $\mathrm{EC}_{\mathrm{e}}$ higher than $3 \mathrm{dS} \mathrm{m}^{-1}$ reduced rice yield, although the rice crop was planted in these soils. This may be attributed to the free water layer on the soil surface during the growing season dilutes and leaches salts to subsurface soil layers; e.g., Apzg and Bssz horizons (Fig. 5a). Furthermore, the high salinity 
values in soil samples, collected when the rice field was dry, could be better attributed to the salt accumulation in the upper parts of the solum by capillary rise and upward movement of solutes within the pedon under poor drainage and high evaporative surface conditions.

The $\mathrm{pH}$ reaction was consistent with ESP values in the cultivated soils at lowland and some midland positions, which could be attributed to the wrong agricultural practices related to water (Khalil et al., 2015) and soil mismanagement indicating a negative anthropogenic impact. ESP values increased ( $>15 \%)$ in the subsurface horizons (e.g., Btn and Btnz horizons) of Nile deltaic plain and bajada plain pedons, indicating sodium hazards. Furthermore, the high values were also detected at some depths (Ap and Bw horizons) within the solum of bajada and alluvial plains under $>30-21 \mathrm{yr}$ of cultivation (Fig. 5d and Fig. 6a) owing to saline groundwater from the Miocene aquifer used for irrigation (Khalil et al., 2015). On the other hand, $\mathrm{pH}$ reaction was consistent with lime content in the native landscapes at upland indicating the natural impact, which has been attributed to eolian inputs of $\mathrm{CaCO}_{3}$ (Hirmas and Graham, 2011). By contrast, the lower values of lime content at lowland, compared with upland, which could be attributed to the accelerated decalcification induced by periodic waterlogging (Van den Berg and Loch, 2000). Consequently, the chemical data in Table (5) showed either a carbonate increase with depth or an irregular increase. Furthermore, the calcite is transformed into bicarbonate and calcium in a flood situation (Huang et al., 2015).

SOC values in the cultivated lowland soils (e.g., delta plain and bajada plain) were high compared with the cultivated highland (alluvial plain) and native land in the piedmont slope and mountains. Yue-Qin et al. (2009) claimed that hydric soils with continuous waterlogging showed higher values of SOC than nonhydric soils.

It has been assumed that during anaerobic conditions the rate of organic matter decomposition is slower and, thus, there is an accumulation of organic matter in the pedon. However, Kögel-Knabner et al. (2010) clarified that the amount of organic input after the harvest (rice straw) is the main reason for the high values in the topsoil in relation to the normal content of hydric soils. The results of this study support those of Yue-Qin et al. (2009), and Kögel-Knabner et al. (2010). To conclude, paddy soil formation is driven by the anthropogenic management practices that mask the soil's original character.

\section{Impacts on pedon horizonation change}

The processes by which soil formation occurs are known collectively as pedogenic processes, and they comprise four main groups: additions, transformations, transfers, and losses (Ellis and Mellor, 1995). Accordingly, there were noticeable differences in the horizon sequence between the irrigated pedons overtime at anthropogenic landscapes (e.g., Nile old deltaic plain, bajada plain, and alluvial plain) (Figs. 5 and $6 \mathrm{a}, \mathrm{b}, \mathrm{c}$ ) and dryland pedons at not-irrigated landscapes (e.g., piedmont slope and mountains) (Figs. 6d and 7). The lowland soil had different horizonation sequences:
Apzg-Btg-Bssz-Btk-Btkm and Ap-E-Btn-Btk-Bt for Nile old deltaic plain, and Ap-Btnz-Bq-C for bajada plain (Fig. 5). Meanwhile, the cultivated pedons at alluvial plain had a homogeneous upper $\mathrm{A}-\mathrm{Bw}-\mathrm{C}$ horizonation which was characterized by a gradual development from the $\mathrm{C}$ soil layer towards the upper Ap soil horizon, through Bw soil horizon (Fig. 6d). The horizon sequences in the alluvial plain soils were: ApBw-BC-C under $>30-21$ yr of cultivation (Fig. 5d and Fig. 6a), Ap-Bw-CB-Ck-Ab under 20-11 yr of cultivation (Fig. 6b), and Ap-C1-Ab-C2 under $\leq 10$ yr of cultivation (Fig. 6c). The thickness of epipedon (Ap) on alluvial plain showed different diversity at the cultivation age level: $63 \mathrm{~cm}$ in the $>30-\mathrm{yr}$ cultivated soils (Fig. 5d), $50 \mathrm{~cm}$ in the $30-21$ yr cultivated soils (Fig. 6a), $35 \mathrm{~cm}$ in the 20-11 yr cultivated soils (Fig. $6 \mathrm{~b}$ ), and $25 \mathrm{~cm}$ in the $\leq 10 \mathrm{yr}$ cultivated soils (Fig. 6c) compared with native pedons (Fig. 6d). Similarly, the depth of solum (Ap or Ap+Bw horizons) across alluvial plain landscape follows a conspicuous decreasing with decreasing age of cultivation: $115 \mathrm{~cm}$ in the $>30-\mathrm{yr}$ cultivated soils, $80 \mathrm{~cm}$ in the $30-y \mathrm{r}$ cultivated soils, 55 $\mathrm{cm}$ in the 20 -yr cultivated soils, and $25 \mathrm{~cm}$ in the $\leq 10 \mathrm{yr}$ cultivated soils that lacked to $\mathrm{Bw}$ horizon. In contrast, the native soil at alluvial plain occurred on the same transect (Fig. 2) had A-C-Ab-2C layer sequence which lacked to develop horizonation. The study demonstrated that the ten years of cultivation wasn't adequate to develop the cambic horizon (Bw) as observed in Fig. (6c) compared with other cultivation ages (Fig. 5d and 6a, b). In comparison, the native landscapes at upland (mountains and piedmont slope landscapes) showed a different layer sequence. The layer sequences of mountain pedons were $\mathrm{C}-2 \mathrm{C}-\mathrm{R}$ at the mountains-free faces and C-2C-3C at the mountainflank (Tables 1, 2 and Fig. 7c, d), while the layer sequence for the piedmont pedons was C-Ck-Ckkm-Ckm at fan piedmont landform and $\mathrm{C}-\mathrm{Ck}-\mathrm{Ckm}-2 \mathrm{C}$ on pediment landform (Tables 1, 2 and Fig. 7a, b). These soils were formed through geologic processes with no evidence of pedogenesis.

\section{Impacts on the formation of diagnostic horizons}

Soils were impacted by agriculture that their original horizons are wholly or partially transformed or buried. The formation of new diagnostic horizons or features was observed in lowland soils as a result of long-term applications of manures under irrigation conditions; consistent with Presley et al., (2004). Consequently, argillic horizons were identified in the cultivated soils on lowland since more than $65 \mathrm{yr}$ of cultivation (Khalifa and Mohamed, 2008). Although argillic horizons require thousands to tens of thousands of years to form in the desert environments (Hirmas and Graham, 2011), the current results observed that they also were encouraged by intensive irrigation which suitable for the chemical weathering and translocation of clay. Argillic horizons may be developed in the lowland soils through the following three processes: clay translocation, clay transformation, and clay neoformation (Nettleton et al., 1975) which have been prompted by long-term manuring and irrigation. Clay translocation was generally described as fine clays 
Table (3): Abbreviated field descriptions and pedogenic features of selected pedons across landscapes over different cultivation ages

\begin{tabular}{|c|c|c|c|c|c|c|c|c|c|c|c|c|}
\hline $\begin{array}{l}\text { Stage and } \\
\text { age of } \\
\text { cultivation }\end{array}$ & $\begin{array}{l}\text { Pedon } \\
\text { No. }\end{array}$ & $\begin{array}{l}\text { Horizon } \\
\text { /layer }\end{array}$ & $\begin{array}{l}\text { Horizon } \\
\text { thickness, } \\
\text { cm }\end{array}$ & $\begin{array}{c}\text { Horizon } \\
\text { boundary }\end{array}$ & $\begin{array}{c}\text { Matrix } \\
\text { color } \\
\text { (Moist) }\end{array}$ & $\begin{array}{l}\text { Redoximorphic } \\
\text { features (Kind) }^{c}\end{array}$ & $\begin{array}{l}\text { Concentrations } \\
\text { (Quantity, size, kind, } \\
\text { location, hardness) }^{\mathrm{d}}\end{array}$ & $\begin{array}{c}\text { Ped } / \text { V. surface } \\
\text { features } \\
\text { (Amount, kind, }_{\text {location) }}{ }^{\mathrm{e}}\end{array}$ & $\begin{array}{l}\text { Structure } \\
\text { (Grade, } \\
\text { size, type) }\end{array}$ & $\begin{array}{l}\text { Consistence } \\
\text { (Dry, moist, } \\
\text { wet) }^{\mathrm{g}}\end{array}$ & $\begin{array}{c}\text { Roots } \\
\text { (Quantity, size, } \\
{\text { location })^{\mathrm{h}}}^{\mathrm{h}}\end{array}$ & Cracks $^{\mathrm{i}}$ \\
\hline \multirow{18}{*}{$\begin{array}{l}\text { Till } 1986 \\
\text { (>30 yr of } \\
\text { cultivation) }\end{array}$} & \multirow{5}{*}{1} & Apzg & 20 & $\mathrm{~A}, \mathrm{~W}$ & 10YR 2/1 & RMX \& F2M & f,1,CAM \&SAX,MAT, EW & vf, BRF,SC & $2, \mathrm{~F}, \mathrm{SBK}$ & MH,FI,MS-MP & $3, \mathrm{~F}, \mathrm{~T}$ & RCR \\
\hline & & Btg & 23 & $\mathrm{C}, \mathrm{I}$ & 7.5YR 3/1 & RMX \& F2M & $\mathrm{m}, 1, \mathrm{FDS} \% \mathrm{SAX}, \mathrm{TOT}, \mathrm{NC}$ & $\mathrm{c}, \mathrm{CLF}, \mathrm{PF} \& \mathrm{BG}$ & $2, \mathrm{M}, \mathrm{ABK}$ & VH,EF,VS-VP & $3, F, P$ & None \\
\hline & & Bssz & 55 & $\mathrm{~A}, \mathrm{~S}$ & $7.5 Y R 3 / 2$ & FMC \& FMN & $\begin{array}{l}\text { m,2, FDS\& SAX, } \\
\text { MAT\&CRK,SSS,VW }\end{array}$ & $\mathrm{c}, \mathrm{SKF}, \mathrm{SS}$ & $3, \mathrm{M}, \mathrm{ABK}$ & HA,VFI,VS-VP & 3,F,P\&C & RTH \\
\hline & & Btk & 52 & $\mathrm{~A}, \mathrm{~W}$ & 10YR 3/2 & FMC \& FMN & $\mathrm{c}, 1, \mathrm{CAN}, \mathrm{MAT}, \mathrm{VW}$ & $\mathrm{m}, \mathrm{FEF}(\mathrm{RMF}), \mathrm{PF}$ & $2, \mathrm{M}, \mathrm{PL}$ & VH, EF,MS-VP & $1, \mathrm{VF}, \mathrm{P}$ & None \\
\hline & & Btkm & 30 & -- & $10 \mathrm{YR} 4 / 1$ & FMC \& FMN & $\mathrm{f}, 1, \mathrm{CAN}, \mathrm{MAT}, \mathrm{W}$ & $\begin{array}{l}\mathrm{m}, \mathrm{MNF} \\
(\mathrm{RMF}), \mathrm{PF}\end{array}$ & $3, \mathrm{C}, \mathrm{PR}$ & EH,SR,VS-VP & $1, \mathrm{~F}, \mathrm{P}$ & None \\
\hline & \multirow{5}{*}{5} & Ap & 45 & $\mathrm{~A}, \mathrm{~S}$ & $10 Y R 3 / 1$ & FEF \& F3M & f,1,CAN,MAT, EW & $\mathrm{c}, \mathrm{SNF}, \mathrm{SC}$ & $1, \mathrm{M}, \mathrm{GR}$ & SH, FR,SS-SP & $3, \mathrm{~F}, \mathrm{~T}$ & None \\
\hline & & E & 30 & $\mathrm{C}, \mathrm{B}$ & 10YR 5/1 & CLD \& FED & $\mathrm{f}, 2, \mathrm{CAN}, \mathrm{MAD}, \mathrm{VW}$ & c, CAF ,NO & $2, \mathrm{~F}, \mathrm{SBK}$ & HA,FI,MS-SP & 2,F,M & None \\
\hline & & Btn & 25 & $\mathrm{~A}, \mathrm{~W}$ & 10YR 4/1 & F3M & m,2,CAN,MAD,W & vm,CLF,PF & $2, \mathrm{M}, \mathrm{ABK}$ & MH,FI,MS-MP & None & None \\
\hline & & Btk & 20 & $\mathrm{~A}, \mathrm{~W}$ & $10 \mathrm{YR} 4 / 2$ & FMN & $\mathrm{c}, 1, \mathrm{CAN}, \mathrm{MAC}, \mathrm{W}$ & vm,CLF,PF & $1, \mathrm{M}, \mathrm{PR}$ & MH,FI,MS-MP & None & None \\
\hline & & $\mathrm{Bt}$ & 35 & -- & 10YR 5/2 & FMN & $\mathrm{f}, 1, \mathrm{CAN}, \mathrm{MAT}, \mathrm{W}$ & $\mathrm{m}, \mathrm{CLF}, \mathrm{PF}$ & $2, \mathrm{M}, \mathrm{ABK}$ & HA,VFI,MS-MP & None & None \\
\hline & \multirow{4}{*}{9} & Ap & 30 & $\mathrm{C}, \mathrm{W}$ & $10 \mathrm{YR} 6 / 4$ & F3M & $\mathrm{c}, 1, \mathrm{FDC}, \mathrm{MAT}, \mathrm{NC}$ & vf,CLF,SC & $2, \mathrm{~F}, \mathrm{GR}$ & MH,FI,MS-SP & $3, \mathrm{~F}-\mathrm{M}, \mathrm{T}$ & RCR \\
\hline & & Btnz & 65 & $\mathrm{C}, \mathrm{B}$ & $10 Y R 5 / 4$ & FEF \& F3M & m,1, CAN,MAT,W & $\mathrm{c}, \mathrm{BRF}, \mathrm{BG}$ & $2, \mathrm{~F}, \mathrm{SBK}$ & HA,VFI,MS-MP & $3, \mathrm{C}, \mathrm{T}$ & None \\
\hline & & $\mathrm{Bq}$ & 25 & $\mathrm{C}, \mathrm{W}$ & $10 \mathrm{YR} 8 / 4$ & F3M & m,1,SIC,MAT,VW & $\mathrm{f}, \mathrm{CAF}, \mathrm{RF}$ & 0, MA & S,L,SO-PO & $1, \mathrm{VF}, \mathrm{M}$ & None \\
\hline & & $\mathrm{C}$ & 35 & -- & $10 \mathrm{YR} 8 / 6$ & F3M & f,1,CAN,MAT,VW & None & $0, \mathrm{SGR}$ & S,L,SO-PO & None & None \\
\hline & \multirow{4}{*}{14} & Ap & 63 & $\mathrm{~A}, \mathrm{~S}$ & $7.5 \mathrm{YR} 4 / 2$ & RMX \& F2M & m,1,FDC,MAT\&RPO,NC & $\mathrm{c}, \mathrm{CAF}, \mathrm{SC}$ & $2, F, G R$ & MH,FI,MS-MP & $3, \mathrm{~F}-\mathrm{M}, \mathrm{T}$ & RCR \\
\hline & & $\mathrm{Bw}$ & 52 & $\mathrm{~A}, \mathrm{~S}$ & $7.5 \mathrm{YR} 6 / 6$ & FEF \& F3M & $\mathrm{c}, 2, \mathrm{CAN}, \mathrm{MAT}, \mathrm{W}$ & $\mathrm{f}, \mathrm{BRF}, \mathrm{PF}$ & $1, \mathrm{~F}, \mathrm{GR}$ & SH,FR,SS-SP & $2, \mathrm{~F}, \mathrm{~T}$ & None \\
\hline & & $\mathrm{BC}$ & 40 & $\mathrm{~A}, \mathrm{~W}$ & 10YR 8/6 & $\mathrm{F} 3 \mathrm{M}$ & f,2,CAN,MAT,EW & $\mathrm{m}, \mathrm{CAF}, \mathrm{RF}$ & $0, \mathrm{MA}$ & SH,FR,SO-PO & $1, \mathrm{VF}, \mathrm{M}$ & None \\
\hline & & $\mathrm{C}$ & 38 & -- & 10 YR $8 / 8$ & $\mathrm{~F} 3 \mathrm{M}$ & f,1,CAN,MAT,EW & None & $0, \mathrm{MA}$ & S,L,SO-PO & None & None \\
\hline \multirow{4}{*}{$\begin{array}{l}1987-1996 \\
(30-21 \text { yr of } \\
\text { cultivation) }\end{array}$} & \multirow{4}{*}{22} & $\mathrm{Ap}$ & 50 & $\mathrm{~A}, \mathrm{~W}$ & $7.5 \mathrm{YR} 4 / 2$ & RMX \& F2M & $\mathrm{m}, 1, \mathrm{FDC}, \mathrm{RPO}, \mathrm{NC}$ & $\mathrm{m}, \mathrm{CAF}, \mathrm{SC}$ & $1, \mathrm{~F}, \mathrm{GR}$ & MH,FI,MS-MP & $3, \mathrm{C}, \mathrm{T}$ & None \\
\hline & & $\mathrm{Bw}$ & 30 & $\mathrm{~A}, \mathrm{~W}$ & 7.5 YR $6 / 8$ & FEF \& F3M & c,1,CAN,MAT,EW & f,BRF,PF & $1, \mathrm{M}, \mathrm{GR}$ & SH,FR,SS-SP & $1, \mathrm{~F}, \mathrm{~T}$ & None \\
\hline & & $\mathrm{BC}$ & 30 & $\mathrm{~A}, \mathrm{~W}$ & 10YR 7/6 & F3M & f,1,CAM,MAT,EW & $\mathrm{f}, \mathrm{CAF}, \mathrm{RF}$ & 0, MA & SH,VFR,SO-PO & $1, \mathrm{VF}, \mathrm{M}$ & None \\
\hline & & $\mathrm{C}$ & 65 & -- & 10YR 8/6 & $\mathrm{F} 3 \mathrm{M}$ & f,1,CAM,MAT,VW & None & 0, SGR & $\mathrm{S}, \mathrm{L}, \mathrm{SO}-\mathrm{PO}$ & None & None \\
\hline \multirow{5}{*}{$\begin{array}{l}1997-2006 \\
(20-11 \text { yr of } \\
\text { cultivation) }\end{array}$} & \multirow{5}{*}{23} & Ap & 35 & $\bar{A}, \mathrm{~W}$ & $7.5 \mathrm{YR} 4 / 4$ & FEF \& F3M & $\mathrm{c}, 1, \mathrm{FDC}, \mathrm{MAT}, \mathrm{NC}$, & $\mathrm{m}, \mathrm{CAF}, \mathrm{SC}$ & $1, \mathrm{~F}, \mathrm{GR}$ & MH,FI,MS-MP & $3, \mathrm{~F}, \mathrm{~T}$ & None \\
\hline & & $\mathrm{Bw}$ & 20 & $\mathrm{~A}, \mathrm{~W}$ & 10YR 6/8 & $\mathrm{F} 3 \mathrm{M}$ & $\mathrm{c}, 2, \mathrm{CAN}, \mathrm{TOH}, \mathrm{VW}$ & $\mathrm{c}, \mathrm{BRF}, \mathrm{PF}$ & $1, \mathrm{~F}, \mathrm{GR}$ & S,L,SO-PO & $2, \mathrm{VF}, \mathrm{T}$ & None \\
\hline & & $\mathrm{CB}$ & 15 & $\mathrm{~A}, \mathrm{~S}$ & 10 YR $8 / 6$ & $\mathrm{~F} 3 \mathrm{M}$ & f,2,CAN,MAT,VW & None & 0, MA & S,VFR,SO-PO & $1, \mathrm{VF}, \mathrm{M}$ & None \\
\hline & & $\mathrm{Ck}$ & 35 & $\mathrm{~A}, \mathrm{~S}$ & $10 \mathrm{YR} 7 / 6$ & F3M & $\mathrm{f}, 1, \mathrm{CAN}, \mathrm{MAT}, \mathrm{W}$ & None & 0, MA & SH,FR,SO-PO & None & None \\
\hline & & $\mathrm{Ab}$ & 50 & -- & 7.5 YR $4 / 6$ & FEF \& F3M & m,1,CAN,MAT,ST & None & $0, \mathrm{SGR}$ & HA,VFI,MS-MP & None & None \\
\hline \multirow{4}{*}{$\begin{array}{l}2007-2016 \\
(\leq 10 \mathrm{yr} \text { of } \\
\text { cultivation) }\end{array}$} & \multirow{4}{*}{24} & Ap & 25 & $\mathrm{~A}, \mathrm{~W}$ & 10YR 6/6 & F3M & $\mathrm{m}, 2, \mathrm{CAC}, \mathrm{TOT}, \mathrm{EW}$ & $\mathrm{m}, \mathrm{CAF}, \mathrm{SC}$ & $1, \mathrm{~F}, \mathrm{GR}$ & MH,FI,MS-SP & $2, \mathrm{~F}, \mathrm{~T}$ & None \\
\hline & & $\mathrm{C} 1$ & 40 & $\mathrm{~A}, \mathrm{~S}$ & 10 YR $8 / 6$ & F3M & f,1,CAN,MAT,EW & None & 0, MA & S,L,SO-PO & $1, \mathrm{VF}, \mathrm{T}$ & None \\
\hline & & $\mathrm{Ab}$ & 45 & $\mathrm{~A}, \mathrm{~S}$ & 7.5 YR $5 / 8$ & F3M & $\mathrm{c}, 2, \mathrm{CAN}, \mathrm{SPO}, \mathrm{VW}$ & $\mathrm{f}, \mathrm{CAF}, \mathrm{RF}$ & $2, \mathrm{~F}, \mathrm{SBK}$ & HA,VFI,MS-MP & $1, \mathrm{VF}, \mathrm{M}$ & None \\
\hline & & $\mathrm{C} 2$ & 40 & -- & $10 \mathrm{YR} 8 / 6$ & None & $\mathrm{f}, 1, \mathrm{CAN}, \mathrm{SPO}, \mathrm{VW}$ & None & 0, MA & S,L,SO-PO & None & None \\
\hline
\end{tabular}


Table (3): Continued

\begin{tabular}{|c|c|c|c|c|c|c|c|c|c|c|c|c|}
\hline $\begin{array}{l}\text { Stage and } \\
\text { age of } \\
\text { cultivation }\end{array}$ & $\begin{array}{c}\text { Pedon } \\
\text { No. }\end{array}$ & $\begin{array}{c}\text { Horizon } \\
\text { /layer }\end{array}$ & $\begin{array}{l}\text { Horizon } \\
\text { thickness, } \\
\text { cm }\end{array}$ & $\begin{array}{c}\text { Horizon } \\
\text { boundary }\end{array}$ & $\begin{array}{l}\text { Matrix color } \\
\text { (Moist) }^{\mathbf{b}}\end{array}$ & $\begin{array}{l}\text { Redoximorphic } \\
\text { features } \\
\text { (Kind) }^{\mathrm{c}}\end{array}$ & $\begin{array}{c}\text { Concentrations } \\
\text { (Quantity, size, kind, } \\
\text { location, hardness) }\end{array}$ & $\begin{array}{l}\text { Ped/V. surface } \\
\text { features } \\
\text { (Amount, } \\
\text { kind, location) }\end{array}$ & $\begin{array}{c}\text { Structure } \\
\text { (Grade, size, }^{\text {type })^{\mathrm{f}}}\end{array}$ & 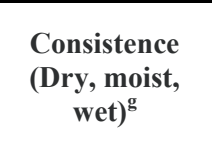 & $\begin{array}{c}\text { Roots } \\
\text { (Quantity, size, }_{\text {location }^{\mathrm{h}}}\end{array}$ & Cracks $^{\mathrm{i}}$ \\
\hline \multirow{17}{*}{$\begin{array}{c}\text { Not-used } \\
\text { land } \\
\text { (Native } \\
\text { land) }\end{array}$} & \multirow{4}{*}{25} & $\mathrm{C} 1$ & 53 & $\mathrm{C}, \mathrm{W}$ & $10 \mathrm{YR} 8 / 3$ & None & $\mathrm{f}, 1, \mathrm{CAN}, \mathrm{MAT}, \mathrm{NC}$ & None & $0, \mathrm{MA}$ & $\mathrm{SH}, \mathrm{FR}, \mathrm{SO}-\mathrm{PO}$ & None & None \\
\hline & & $\mathrm{C} 2$ & 62 & $\mathrm{C}, \mathrm{W}$ & 7.5 YR $5 / 4$ & None & $\mathrm{m}, 2, \mathrm{CAN}, \mathrm{SPO}, \mathrm{ST}$ & None & $2, \mathrm{M}, \mathrm{SBK}$ & VH,EF,MS-MP & None & None \\
\hline & & $\mathrm{Ab}$ & 35 & $\mathrm{~A}, \mathrm{~W}$ & 10YR $8 / 4$ & None & $\mathrm{mc}, 2, \mathrm{CAN}, \mathrm{ARF}, \mathrm{W}$ & None & 0, MA & MH,FR,SO-PO & None & None \\
\hline & & $2 \mathrm{C}$ & & -- & 10YR 6/8 & None & $\mathrm{f}, 1, \mathrm{CAN}, \mathrm{MAT}, \mathrm{NC}$ & None & 0, MA & VH,EF,MS-MP & None & None \\
\hline & \multirow{4}{*}{31} & $\mathrm{C}$ & 15 & $\mathrm{~A}, \mathrm{~W}$ & $10 \mathrm{YR} 6 / 6$ & None & $\mathrm{c}, 1, \mathrm{CAM}, \mathrm{SPO}, \mathrm{NC}$ & None & $0, \mathrm{MA}$ & SH,FR,SS-SP & $1, \mathrm{VF}, \mathrm{M}$ & None \\
\hline & & $\mathrm{Ck}$ & 55 & $\mathrm{~A}, \mathrm{~S}$ & 10YR 6/8 & None & c,1,CAN,MAT,EW & None & $0, \mathrm{MA}$ & MH,FI,SS-SP & None & None \\
\hline & & Ckkm & 30 & $\mathrm{C}, \mathrm{W}$ & 10YR 6/6 & None & $\mathrm{m}, 2, \mathrm{CAN}, \mathrm{MAT}, \mathrm{W}$ & None & 0, MA & HA,VFI,SS-SP & None & None \\
\hline & & $\mathrm{Ckm}$ & 35 & -- & 10YR 6/8 & None & c,2,CAN,MAT,VW & None & $0, \mathrm{MA}$ & HA,FI,SS-SP & None & None \\
\hline & \multirow{4}{*}{35} & $\mathrm{C}$ & 15 & $\mathrm{~A}, \mathrm{~W}$ & 10YR 7/8 & None & f,1,CAN,MAT,VW & None & 0, SGR & SH,FR,SO-PO & None & None \\
\hline & & $\mathrm{Ck}$ & 20 & $\mathrm{~A}, \mathrm{~W}$ & 10YR 6/8 & None & c,2,CAN,MAT,VW & None & $0, \mathrm{MA}$ & SH,FI,SO-PO & None & None \\
\hline & & $\mathrm{Ckm}$ & 25 & $\mathrm{~A}, \mathrm{~S}$ & 10YR 6/6 & None & m,1,CAN,ARF,EW & None & 0, MA & MH,FI,SO-PO & None & None \\
\hline & & $2 \mathrm{C}$ & 40 & -- & 10YR 7/6 & None & $\mathrm{m}, 2, \mathrm{CAN}, \mathrm{ARF}, \mathrm{W}$ & None & 0, MA & MH,FI,SO-PO & None & None \\
\hline & \multirow{3}{*}{40} & $\mathrm{C}$ & 10 & $\mathrm{~A}, \mathrm{~W}$ & 10 YR $8 / 3$ & None & f,1,CAM,SPO,EW & None & $0, \mathrm{MA}$ & SH,FR,SO-PO & None & None \\
\hline & & $2 \mathrm{C}$ & 30 & $\mathrm{~A}, \mathrm{~S}$ & 10YR $7 / 8$ & None & c,1,CAN,MAT,VW & None & $0, \mathrm{MA}$ & MH,FI,SO-PO & None & None \\
\hline & & $3 \mathrm{Cr}$ & 25 & -- & $10 \mathrm{YR} 7 / 6$ & None & m,2,CAN,ARF,W & None & $0, \mathrm{SGR}$ & SH,FR,SO-PO & None & None \\
\hline & \multirow{2}{*}{43} & $\mathrm{C}$ & 5 & $\mathrm{~A}, \mathrm{~W}$ & $10 \mathrm{YR} 8 / 2$ & None & f,1,CAN,ARF,NC & None & 0, SGR & SH,FR,SO-PO & None & None \\
\hline & & $\mathrm{Cr}$ & 20 & $\mathrm{~A}, \mathrm{~S}$ & $10 \mathrm{YR} 7 / 2$ & None & f,2,CAN,MAT,NC & None & $0, \mathrm{SGR}$ & SH,FR,SO-PO & None & None \\
\hline
\end{tabular}

All symbols are used based on Schoeneberger et al. (2012).

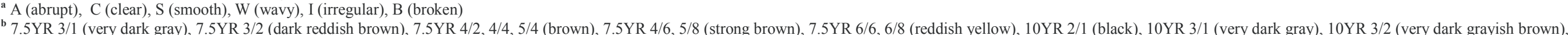

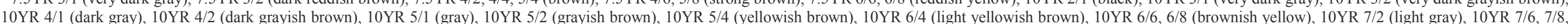
$8 / 6,8 / 8$ (yellow), 10YR 8/2,8/3, 8/4 (very pale brown).

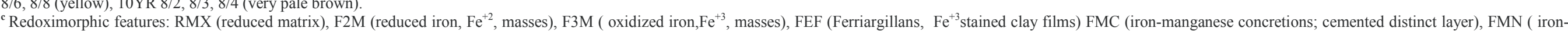

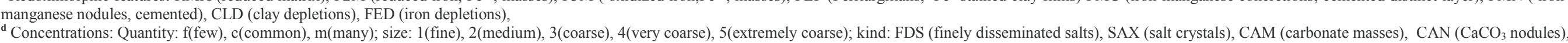

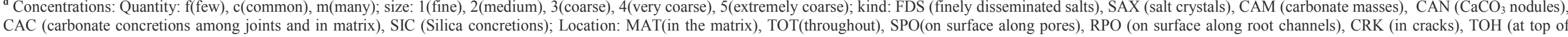
horizon), ARF (around rock fragments), SSS (on slickensides). Hardness: NC (non-cemented), EW (extremely weakly cemented), VW (very weakly cemented), W (weakly cemented), ST(strongly cemented).

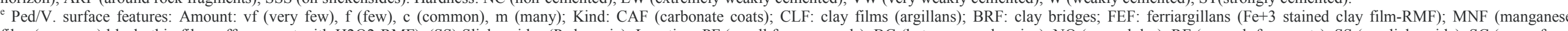

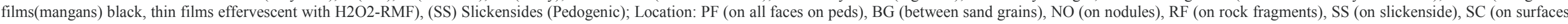
along root channels)

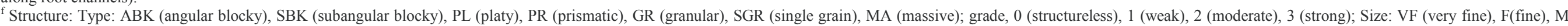
(medium) CO (coarse), VC (very coarse), EC (extremely coarse)

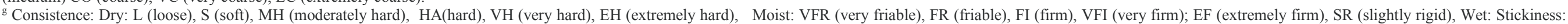
SO (nonsticky), SS (slightly sticky), MS (moderately sticky), VS (very sticky), PLASTICITY: PO (nonplastic), SP (slightly plastic), MP (moderately plastic), VP (very plastic).

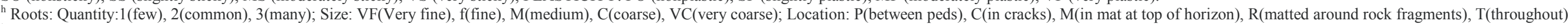

${ }^{i}$ Cracks: RTH: Reversible Trans-Horizon Cracks; RCR: Reversible Crust-Related Cracks . 
Table (4): Physical properties of soils in a toposequence in Wadi Al-Molak study area

\begin{tabular}{|c|c|c|c|c|c|c|c|c|c|c|c|}
\hline \multirow[b]{2}{*}{$\begin{array}{l}\text { Stage and } \\
\text { age of } \\
\text { cultivation }\end{array}$} & \multirow[b]{2}{*}{$\begin{array}{l}\text { Pedons } \\
\text { ID }\end{array}$} & \multirow[b]{2}{*}{$\begin{array}{c}\text { Horizon } \\
\text { /layer }\end{array}$} & \multirow[b]{2}{*}{$\begin{array}{l}\text { Gravel } \\
\left(\mathrm{g} \mathrm{kg}^{-1}\right)\end{array}$} & \multicolumn{6}{|c|}{ Fine-earth fractions $\left(\mathrm{g} \mathrm{kg}^{-1}\right)$} & \multirow[b]{2}{*}{$\begin{array}{c}\text { A.W. } \\
(\%)\end{array}$} & \multirow[b]{2}{*}{$\begin{array}{c}\text { Bulk } \\
\text { density } \\
\left(\mathrm{g} \mathrm{cm}^{-3}\right)\end{array}$} \\
\hline & & & & $\begin{array}{c}\text { Coarse } \\
\text { sand }\end{array}$ & $\begin{array}{c}\text { Sand } \\
\text { Mediu } \\
\text { m sand }\end{array}$ & $\begin{array}{l}\text { Fine } \\
\text { sand }\end{array}$ & Silt & Clay & Textural class & & \\
\hline \multirow{18}{*}{$\begin{array}{c}\text { Till } 1986 \\
\text { ( } \geq 31 \text { yr of } \\
\text { cultivation) }\end{array}$} & \multirow{5}{*}{$\begin{array}{l}\text { I-Dipped } \\
\text { delta } \\
\text { (Lowland) }\end{array}$} & Apzg & $0.0 \pm 0.0$ & $15 \pm 3$ & $43 \pm 7$ & $67 \pm 5$ & $356 \pm 10$ & $519 \pm 13$ & Clay & $49.5 \pm 3.5$ & $1.19 \pm 0.01$ \\
\hline & & Btg & $0.0 \pm 0.0$ & $11 \pm 1$ & $13 \pm 2$ & $139 \pm 11$ & $294 \pm 15$ & $543 \pm 25$ & Clay & $57.2 \pm 6.1$ & $1.31 \pm 0.07$ \\
\hline & & Bssz & $11 \pm 3$ & $9 \pm 2$ & $12 \pm 1$ & $72 \pm 5$ & $399 \pm 11$ & $508 \pm 19$ & Clay & $51.7 \pm 3.4$ & $1.28 \pm 0.03$ \\
\hline & & Btk & $9 \pm 2$ & $5 \pm 0.7$ & $15 \pm 3$ & $92 \pm 9$ & $292 \pm 9$ & $596 \pm 17$ & Clay & $50.5 \pm 2.5$ & $1.39 \pm 0.04$ \\
\hline & & Btkm & $5 \pm 0.8$ & $7 \pm 1$ & $32 \pm 5$ & $83 \pm 4$ & $244 \pm 3$ & $634 \pm 23$ & Clay & $45.1 \pm 1.5$ & $1.41 \pm 0.02$ \\
\hline & \multirow{5}{*}{$\begin{array}{l}\text { II-Raised } \\
\text { delta } \\
\text { (Lowland) }\end{array}$} & Ap & $13 \pm 2$ & $12 \pm 2$ & $25 \pm 4$ & $139 \pm 6$ & $310 \pm 8$ & $514 \pm 19$ & Clay & $39.5 \pm 2.4$ & $1.17 \pm 0.04$ \\
\hline & & $\mathrm{E}$ & $14 \pm 3$ & $35 \pm 6$ & $126 \pm 11$ & $75 \pm 4$ & $373 \pm 5$ & $391 \pm 9$ & Clay loam & $35.7 \pm 1.5$ & $1.23 \pm 0.09$ \\
\hline & & Btn & $9 \pm 0.9$ & $23 \pm 4$ & $34 \pm 3$ & $124 \pm 6$ & $233 \pm 3$ & $586 \pm 21$ & Clay & $41.5 \pm 3.5$ & $1.42 \pm 0.04$ \\
\hline & & Btk & $12 \pm 3$ & $18 \pm 3$ & $61 \pm 5$ & $159 \pm 3$ & $189 \pm 11$ & $573 \pm 24$ & Clay & $42.0 \pm 2.3$ & $1.31 \pm 0.01$ \\
\hline & & $\mathrm{Bt}$ & $8 \pm 2$ & $16 \pm 4$ & $25 \pm 3$ & $93 \pm 4$ & $331 \pm 12$ & $535 \pm 19$ & Clay & $39.2 \pm 7.1$ & $1.29 \pm 0.07$ \\
\hline & \multirow{4}{*}{$\begin{array}{l}\text { III-Bajada } \\
\text { plain } \\
\text { (Lowland) }\end{array}$} & Ap & $15 \pm 7$ & $18 \pm 5$ & $19 \pm 1$ & $51 \pm 1$ & $538 \pm 23$ & $374 \pm 13$ & Silty clay loam & $25.1 \pm 1.5$ & $1.45 \pm 0.09$ \\
\hline & & Btnz & $18 \pm 5$ & $47 \pm 9$ & $91 \pm 6$ & $232 \pm 9$ & $385 \pm 11$ & $245 \pm 12$ & Loam & $20.5 \pm 3.5$ & $1.47 \pm 0.04$ \\
\hline & & $\mathrm{Bq}$ & $11 \pm 14$ & $71 \pm 10$ & $135 \pm 12$ & $254 \pm 8$ & $387 \pm 14$ & $153 \pm 9$ & Loam & $15.6 \pm 2.5$ & $1.46 \pm 0.01$ \\
\hline & & $\mathrm{C}$ & $19 \pm 3$ & $82 \pm 13$ & $45 \pm 4$ & $367 \pm 11$ & $365 \pm 16$ & $142 \pm 4$ & Loam & $10.5 \pm 3.1$ & $1.54 \pm 0.04$ \\
\hline & \multirow{4}{*}{$\begin{array}{c}\text { IV- } \\
\text { Alluvial } \\
\text { plain } \\
\text { (Midland) }\end{array}$} & Ap & $15 \pm 7$ & $9 \pm 0.7$ & $32 \pm 6$ & $135 \pm 4$ & $487 \pm 14$ & $337 \pm 3$ & Silty clay loam & $29.7 \pm 2.5$ & $1.41 \pm 0.07$ \\
\hline & & $\mathrm{Bw}$ & $32 \pm 2$ & $38 \pm 3$ & $88 \pm 2$ & $195 \pm 6$ & $444 \pm 16$ & $235 \pm 14$ & Loam & $17.1 \pm 1.5$ & $1.46 \pm 0.06$ \\
\hline & & $\mathrm{BC}$ & $54 \pm 8$ & $93 \pm 11$ & $215 \pm 9$ & $274 \pm 9$ & $224 \pm 4$ & $194 \pm 11$ & Sandy loam & $7.1 \pm 1.4$ & $1.24 \pm 0.02$ \\
\hline & & $\mathrm{C}$ & $55 \pm 9$ & $126 \pm 17$ & $295 \pm 11$ & $383 \pm 13$ & $161 \pm 6$ & $35 \pm 1$ & Loamy sand & $5.5 \pm 0.8$ & $1.60 \pm 0.07$ \\
\hline \multirow{4}{*}{$\begin{array}{c}1987-1996 \\
(30-21 \mathrm{yr} \\
\text { of } \\
\text { cultivation) }\end{array}$} & \multirow{4}{*}{$\begin{array}{l}\text { V-Alluvial } \\
\text { plain } \\
\text { (Midland) }\end{array}$} & Ap & $27 \pm 1$ & $100 \pm 12$ & $294 \pm 6$ & $181 \pm 9$ & $94 \pm 4$ & $331 \pm 3$ & Sandy clay loam & $26.1 \pm 2.5$ & $0.95 \pm 0.04$ \\
\hline & & $\mathrm{Bw}$ & $36 \pm 7$ & $51 \pm 5$ & $96 \pm 4$ & $335 \pm 15$ & $280 \pm 7$ & $238 \pm 7$ & loam & $13.4 \pm 1.7$ & $1.10 \pm 0.08$ \\
\hline & & $\mathrm{BC}$ & $45 \pm 12$ & $125 \pm 10$ & $154 \pm 8$ & $411 \pm 21$ & $135 \pm 5$ & $175 \pm 6$ & Sandy loam & $9.1 \pm 1.5$ & $1.11 \pm 0.04$ \\
\hline & & $\mathrm{C}$ & $55 \pm 11$ & $226 \pm 13$ & $335 \pm 13$ & $295 \pm 18$ & $71 \pm 3$ & $73 \pm 9$ & Loamy sand & $6.4 \pm 1.5$ & $1.31 \pm 0.9$ \\
\hline \multirow{5}{*}{$\begin{array}{c}1997-2006 \\
(20-11 \mathrm{yr} \\
\text { of } \\
\text { cultivation) }\end{array}$} & \multirow{5}{*}{$\begin{array}{c}\text { VI- } \\
\text { Alluvial } \\
\text { plain } \\
\text { (Midland) }\end{array}$} & Ap & $30 \pm 13$ & $44 \pm 3$ & $94 \pm 1$ & $124 \pm 9$ & $527 \pm 21$ & $211 \pm 11$ & Silt loam & $27.1 \pm 1$ & $1.01 \pm 0.02$ \\
\hline & & $\mathrm{Bw}$ & $19 \pm 2$ & $89 \pm 8$ & $291 \pm 9$ & $195 \pm 8$ & $210 \pm 8$ & $215 \pm 12$ & Sandy clay loam & $11.2 \pm 2.5$ & $1.01 \pm 0.08$ \\
\hline & & $\mathrm{CB}$ & $45 \pm 6$ & $136 \pm 6$ & $287 \pm 11$ & $245 \pm 6$ & $195 \pm 3$ & $137 \pm 9$ & Sandy loam & $6.1 \pm 0.7$ & $1.21 \pm 0.07$ \\
\hline & & $\mathrm{Ck}$ & $52 \pm 1$ & $175 \pm 8$ & $325 \pm 12$ & $143 \pm 7$ & $254 \pm 9$ & $103 \pm 7$ & Sandy loam & $5.5 \pm 0.9$ & $1.23 \pm 0.08$ \\
\hline & & $\mathrm{Ab}$ & $36 \pm 5$ & $59 \pm 3$ & $228 \pm 16$ & $335 \pm 12$ & $174 \pm 7$ & $204 \pm 8$ & Sandy clay loam & $18.1 \pm 1.5$ & $1.29 \pm 0.01$ \\
\hline \multirow{4}{*}{$\begin{array}{c}2007-2016 \\
(\leq 10 \text { yr of } \\
\text { cultivation) }\end{array}$} & \multirow{4}{*}{$\begin{array}{c}\text { VII- } \\
\text { Alluvial } \\
\text { plain } \\
\text { (Midland) }\end{array}$} & Ap & $55 \pm 17$ & $92 \pm 9$ & $315 \pm 13$ & $215 \pm 5$ & $179 \pm 7$ & $199 \pm 9$ & Sandy loam & $26.2 \pm 0.5$ & $0.98 \pm 0.04$ \\
\hline & & $\mathrm{C} 1$ & $53 \pm 19$ & $192 \pm 10$ & $275 \pm 8$ & $134 \pm 1$ & $274 \pm 6$ & $125 \pm 3$ & Sandy loam & $9.2 \pm 0.7$ & $1.10 \pm 0.12$ \\
\hline & & $\mathrm{Ab}$ & $31 \pm 9$ & $79 \pm 5$ & $176 \pm 9$ & $176 \pm 3$ & $295 \pm 4$ & $274 \pm 8$ & Clay loam & $17.2 \pm 1.5$ & $1.15 \pm 0.07$ \\
\hline & & $\mathrm{C} 2$ & $51 \pm 15$ & $235 \pm 13$ & $292 \pm 7$ & $152 \pm 9$ & $265 \pm 5$ & $56 \pm 9$ & Sandy loam & $6.2 \pm 0.6$ & $1.27 \pm 0.12$ \\
\hline & & $\mathrm{C} 1$ & $132 \pm 21$ & $134 \pm 12$ & $312 \pm 7$ & $251 \pm 15$ & $206 \pm 8$ & $97 \pm 9$ & Sandy loam & $6.1 \pm 0.4$ & $1.15 \pm 0.05$ \\
\hline & Alluvial & $\mathrm{C} 2$ & $155 \pm 13$ & $276 \pm 13$ & $287 \pm 6$ & $273 \pm 9$ & $85 \pm 2$ & $79 \pm 5$ & Loamy sand & $5.7 \pm 0.5$ & $1.27 \pm 0.2$ \\
\hline & & $\mathrm{Ab}$ & $125 \pm 9$ & $85 \pm 9$ & $142 \pm 7$ & $211 \pm 16$ & $271 \pm 3$ & $291 \pm 13$ & Clay loam & $13.2 \pm 2.5$ & $1.19 \pm 0.1$ \\
\hline & & $2 \mathrm{C}$ & $132 \pm 5$ & $286 \pm 11$ & $214 \pm 6$ & $265 \pm 17$ & $157 \pm 1$ & $78 \pm 8$ & Sandy loam & $4.9 \pm 1.6$ & $1.21 \pm 0.07$ \\
\hline & IX- & $\mathrm{C}$ & $95 \pm 12$ & $142 \pm 12$ & $373 \pm 6$ & $215 \pm 12$ & $206 \pm 8$ & $64 \pm 7$ & Sandy loam & $7.1 \pm 1.7$ & $1.41 \pm 0.07$ \\
\hline & Piedmont & $\mathrm{Ck}$ & $112 \pm 6$ & $259 \pm 9$ & $364 \pm 7$ & $185 \pm 5$ & $140 \pm 9$ & $52 \pm 9$ & Loamy sand & $6.1 \pm 1.6$ & $1.57 \pm 0.09$ \\
\hline & & Ckkm & $101 \pm 5$ & $235 \pm 15$ & $342 \pm 8$ & $262 \pm 11$ & $106 \pm 12$ & $55 \pm 6$ & Loamy sand & $6.9 \pm 0.9$ & $1.58 \pm 0.08$ \\
\hline Native land & & $\mathrm{Ckm}$ & $92 \pm 19$ & $187 \pm 11$ & $383 \pm 9$ & $271 \pm 13$ & $96 \pm 3$ & $63 \pm 7$ & Loamy sand & $4.6 \pm 0.7$ & $1.61 \pm 0.05$ \\
\hline agl & & $\mathrm{C}$ & $171 \pm 31$ & $271 \pm 12$ & $398 \pm 8$ & $183 \pm 6$ & $93 \pm 11$ & $55 \pm 7$ & Loamy sand & $4.3 \pm 0.6$ & $1.51 \pm 0.1$ \\
\hline & Piedmont & $\mathrm{Ck}$ & $256 \pm 8$ & $251 \pm 9$ & $413 \pm 16$ & $201 \pm 11$ & $58 \pm 5$ & $77 \pm 3$ & Loamy sand & $5.2 \pm 0.8$ & $1.54 \pm 0.1$ \\
\hline & & $\mathrm{Ckm}$ & $352 \pm 11$ & $334 \pm 15$ & $304 \pm 4$ & $235 \pm 6$ & $66 \pm 9$ & $61 \pm 4$ & Loamy sand & $5.5 \pm 0.6$ & $1.56 \pm 0.09$ \\
\hline & (l & $2 \mathrm{C}$ & $453 \pm 51$ & $238 \pm 17$ & $347 \pm 9$ & $301 \pm 5$ & $68 \pm 8$ & $46 \pm 1$ & Sand & $3.1 \pm 0.2$ & $1.60 \pm 0.08$ \\
\hline & XI- & $\mathrm{C}$ & $355 \pm 27$ & $334 \pm 12$ & $401 \pm 14$ & $172 \pm 8$ & $46 \pm 7$ & $47 \pm 8$ & Sand & $4.2 \pm 0.2$ & $1.56 \pm 0 . .04$ \\
\hline & Mountains & $2 \mathrm{C}$ & $215 \pm 9$ & $312 \pm 25$ & $341 \pm 9$ & $214 \pm 7$ & $70 \pm 8$ & $63 \pm 6$ & Loamy sand & $7.1 \pm 1.1$ & $1.58 \pm 0.05$ \\
\hline & & $3 \mathrm{Cr}$ & $551 \pm 25$ & $296 \pm 21$ & $395 \pm 11$ & $255 \pm 5$ & $23 \pm 6$ & $31 \pm 2$ & Sand & $4.0 \pm 0.6$ & $1.61 \pm 0.1$ \\
\hline & XII- & $\mathrm{C}$ & $352 \pm 64$ & $395 \pm 11$ & $356 \pm 14$ & $152 \pm 11$ & $74 \pm 7$ & $23 \pm 4$ & Sand & $3.4 \pm 0.5$ & $1.63 \pm 0.09$ \\
\hline & $\begin{array}{l}\text { Mountains } \\
\text { (upland) }\end{array}$ & $\mathrm{Cr}$ & $375 \pm 35$ & $415 \pm 19$ & $333 \pm 11$ & $179 \pm 12$ & $57 \pm 6$ & $16 \pm 1$ & Sand & $3.2 \pm 0.3$ & $1.65 \pm 0.02$ \\
\hline
\end{tabular}


Table (5): Soil chemical characteristics in a catena of Wadi Al-Molak

\begin{tabular}{|c|c|c|c|c|c|c|c|c|c|c|c|}
\hline $\begin{array}{l}\text { Stage and } \\
\text { age of } \\
\text { cultivation }\end{array}$ & Pedon ID & $\begin{array}{l}\text { Horizon } \\
\text { /layer }\end{array}$ & $\begin{array}{c}\mathbf{E C}_{\mathrm{e}} \\
\mathrm{dS} / \mathbf{m}\end{array}$ & pH & $\begin{array}{l}\text { SOC } \\
(\%)\end{array}$ & $\begin{array}{c}\text { Total N } \\
(\%)\end{array}$ & 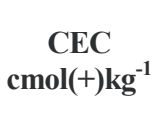 & $\begin{array}{l}\text { ESP } \\
(\%)\end{array}$ & $\begin{array}{c}\mathrm{CaCO}_{3} \\
(\%)\end{array}$ & $\begin{array}{c}\text { Gypsum } \\
(\%)\end{array}$ & $\begin{array}{c}\text { Free } \\
\mathrm{Fe}_{2} \mathrm{O}_{3} \\
(\%)\end{array}$ \\
\hline \multirow{18}{*}{$\begin{array}{l}\text { Till } 1986 \\
\text { (>30 yr of } \\
\text { cultivation) }\end{array}$} & \multirow{5}{*}{$\begin{array}{l}\text { I } \\
\text { Dipped } \\
\text { delta } \\
\text { (Lowland) }\end{array}$} & $\overline{A p z g}$ & $23.9 \pm 2.9$ & $8.9 \pm 0.2$ & $0.75 \pm 0.21$ & $0.51 \pm 0.03$ & $60.5 \pm 6.7$ & $16.5 \pm 1.8$ & $3.5 \pm 1.1$ & $1.2 \pm 0.21$ & $5.9 \pm 1.8$ \\
\hline & & Btg & $20.5 \pm 2.7$ & $8.8 \pm 0.3$ & $0.53 \pm 0.15$ & $0.49 \pm 0.03$ & $55.1 \pm 7.2$ & $15.9 \pm 2.9$ & $4.4 \pm 0.9$ & $2.2 \pm 0.30$ & $6.3 \pm 1.2$ \\
\hline & & Bssz & $31.2 \pm 1.8$ & $8.6 \pm 0.2$ & $0.51 \pm 0.13$ & $0.39 \pm 0.02$ & $51.4 \pm 6.7$ & $14.7 \pm 2.8$ & $7.5 \pm 2.1$ & $1.5 \pm 0.91$ & $4.1 \pm 1.7$ \\
\hline & & Btk & $13.3 \pm 2.4$ & $8.9 \pm 0.3$ & $0.50 \pm 0.10$ & $0.25 \pm 0.02$ & $52.5 \pm 6.9$ & $13.5 \pm 1.7$ & $8.4 \pm 0.7$ & $1.1 \pm 0.11$ & $6.6 \pm 1.6$ \\
\hline & & Btkm & $8.3 \pm 1.6$ & $8.6 \pm 0.1$ & $0.45 \pm 0.09$ & $0.13 \pm 0.01$ & $51.4 \pm 8.1$ & $13.1 \pm 1.9$ & $8.1 \pm 1.5$ & $0.9 \pm 0.08$ & $7.5 \pm 0.9$ \\
\hline & \multirow{5}{*}{$\begin{array}{l}\text { II } \\
\text { Raised } \\
\text { delta } \\
\text { (Lowland) }\end{array}$} & Ap & $13.1 \pm 2.4$ & $8.7 \pm 0.2$ & $0.82 \pm 0.12$ & $0.46 \pm 0.03$ & $55.1 \pm 7.1$ & $15.5 \pm 3.1$ & $5.5 \pm 0.5$ & $0.7 \pm 0.01$ & $3.5 \pm 0.7$ \\
\hline & & $\mathrm{E}$ & $5.5 \pm 1.9$ & $8.6 \pm 0.1$ & $0.61 \pm 0.09$ & $0.33 \pm 0.02$ & $31.8 \pm 3.5$ & $16.7 \pm 3.7$ & $5.9 \pm 1.1$ & $0.6 \pm 0.03$ & $1.9 \pm 0.2$ \\
\hline & & Btn & $8.1 \pm 0.8$ & $9.0 \pm 0.4$ & $0.49 \pm 0.05$ & $0.20 \pm 0.1$ & $27.4 \pm 2.7$ & $17.9 \pm 2.6$ & $7.2 \pm 2.4$ & $0.3 \pm 0.02$ & $6.4 \pm 1.6$ \\
\hline & & Btk & $6.1 \pm 0.7$ & $8.7 \pm 0.2$ & $0.44 \pm 0.03$ & $0.17 \pm 0.1$ & $22.5 \pm 3.9$ & $16.3 \pm 0.9$ & $8.1 \pm 3.1$ & $0.8 \pm 0.03$ & $6.5 \pm 1.7$ \\
\hline & & $\mathrm{Bt}$ & $5.5 \pm 1.1$ & $8.6 \pm 0.1$ & $0.40 \pm 0.02$ & $0.15 \pm 0.0$ & $19.4 \pm 1.9$ & $13.1 \pm 0.7$ & $8.3 \pm 1.8$ & $0.3 \pm 0.01$ & $7.8 \pm 0.8$ \\
\hline & \multirow{4}{*}{$\begin{array}{l}\text { III } \\
\text { Bajada } \\
\text { plain } \\
\text { (Lowland) }\end{array}$} & Ap & $12.1 \pm 1.4$ & $8.7 \pm 0.3$ & $0.25 \pm 0.07$ & $0.31 \pm 0.02$ & $15.3 \pm 3.1$ & $16.5 \pm 3.1$ & $7.5 \pm 1.7$ & $0.5 \pm 0.02$ & $5.2 \pm 1.7$ \\
\hline & & Btnz & $30.5 \pm 2.6$ & $8.5 \pm 0.2$ & $0.35 \pm 0.09$ & $0.25 \pm 0.02$ & $13.9 \pm 1.8$ & $19.2 \pm 2.9$ & $8.2 \pm 1.6$ & $0.2 \pm 0.03$ & $6.1 \pm 0.5$ \\
\hline & & $\mathrm{Bq}$ & $6.2 \pm 1.8$ & $8.4 \pm 0.3$ & $0.15 \pm 0.06$ & $0.13 \pm 0.01$ & $10.8 \pm 2.7$ & $14.3 \pm 3.8$ & $8.9 \pm 1.9$ & $0.3 \pm 0.04$ & $3.9 \pm 1.3$ \\
\hline & & $\mathrm{C}$ & $5.7 \pm 0.5$ & $8.3 \pm 0.7$ & $0.09 \pm 0.04$ & $0.12 \pm 0.01$ & $8.5 \pm 1.7$ & $12.7 \pm 1.5$ & $9.2 \pm 2.1$ & $0.1 \pm 0.01$ & $4.1 \pm 1.7$ \\
\hline & \multirow{4}{*}{$\begin{array}{l}\text { IV } \\
\text { Alluvial } \\
\text { plain } \\
\text { (Midland) }\end{array}$} & Ap & $9.1 \pm 1.6$ & $8.4 \pm 0.5$ & $0.16 \pm 0.1$ & $0.30 \pm 0.02$ & $15.1 \pm 3.5$ & $15.9 \pm 2.7$ & $7.2 \pm 1.3$ & $0.4 \pm 0.02$ & $3.8 \pm 2.0$ \\
\hline & & Bw & $5.8 \pm 1.2$ & $8.5 \pm 0.3$ & $0.13 \pm 0.03$ & $0.21 \pm 0.01$ & $13.8 \pm 2.9$ & $16.1 \pm 3.4$ & $7.5 \pm 1.7$ & $0.3 \pm 0.04$ & $4.8 \pm 1.6$ \\
\hline & & $\mathrm{BC}$ & $4.7 \pm 1.7$ & $8.0 \pm 0.4$ & $0.09 \pm 0.02$ & $0.09 \pm 0.01$ & $8.6 \pm 1.9$ & $11.3 \pm 1.4$ & $8.5 \pm 0.8$ & $0.3 \pm 0.01$ & $3.1 \pm 1.3$ \\
\hline & & $\mathrm{C}$ & $3.6 \pm 1.5$ & $8.1 \pm 0.2$ & $0.07 \pm 0.01$ & $0.08 \pm 0.01$ & $7.1 \pm 1.5$ & $11.1 \pm 0.9$ & $9.7 \pm 1.4$ & $0.1 \pm 0.01$ & $3.9 \pm 0.8$ \\
\hline \multirow{4}{*}{$\begin{array}{l}1987-1996 \\
(30-21 \text { yr of } \\
\text { cultivation) }\end{array}$} & \multirow{4}{*}{$\begin{array}{l}\text { V } \\
\text { Alluvial } \\
\text { plain } \\
\text { (Midland) }\end{array}$} & Ap & $10.9 \pm 1.5$ & $8.7 \pm 0.3$ & $0.31 \pm 0.09$ & $0.25 \pm 0.03$ & $14.8 \pm 3.5$ & $17.7 \pm 2.5$ & $13.2 \pm 0.9$ & $0.3 \pm 0.02$ & $3.6 \pm 1.7$ \\
\hline & & Bw & $9.1 \pm 2.4$ & $8.5 \pm 0.1$ & $0.17 \pm 0.07$ & $0.21 \pm 0.02$ & $13.5 \pm 2.9$ & $15.5 \pm 1.1$ & $15.2 \pm 3.7$ & $0.2 \pm 0.03$ & $4.3 \pm 1.1$ \\
\hline & & $\mathrm{BC}$ & $5.6 \pm 2.6$ & $8.3 \pm 0.4$ & $0.08 \pm 0.01$ & $0.07 \pm 0.01$ & $9.5 \pm 1.9$ & $14.5 \pm 2.1$ & $16.0 \pm 2.6$ & $0.1 \pm 0.01$ & $3.2 \pm 0.9$ \\
\hline & & $\mathrm{C}$ & $4.5 \pm 1.3$ & $8.1 \pm 0.3$ & $0.03 \pm 0.01$ & $0.04 \pm 0.0$ & $6.8 \pm 2.1$ & $13.2 \pm 1.8$ & $16.5 \pm 3.4$ & $0.1 \pm 0.01$ & $3.1 \pm 1.3$ \\
\hline \multirow{5}{*}{$\begin{array}{l}1997-2006 \\
(20-11 \text { yr of } \\
\text { cultivation) }\end{array}$} & \multirow{5}{*}{$\begin{array}{l}\text { VI } \\
\text { Alluvial } \\
\text { plain } \\
\text { (Midland) }\end{array}$} & Ap & $6.3 \pm 1.8$ & $8.5 \pm 0.5$ & $0.30 \pm 0.06$ & $0.23 \pm 0.03$ & $11.5 \pm 1.2$ & $15.2 \pm 1.5$ & $11.2 \pm 3.7$ & $0.4 \pm 0.01$ & $2.4 \pm 0.9$ \\
\hline & & Bw & $6.1 \pm 1.2$ & $8.6 \pm 0.4$ & $0.21 \pm 0.05$ & $0.15 \pm 0.04$ & $10.9 \pm 1.6$ & $16.3 \pm 2.3$ & $14.0 \pm 2.8$ & $0.2 \pm 0.04$ & $3.8 \pm 1.0$ \\
\hline & & $\mathrm{CB}$ & $5.7 \pm 1.1$ & $8.5 \pm 0.1$ & $0.16 \pm 0.03$ & $0.05 \pm 0.0$ & $8.1 \pm 0.9$ & $15.5 \pm 3.1$ & $15.1 \pm 3.7$ & $0.3 \pm 0.03$ & $3.2 \pm 1.3$ \\
\hline & & $\mathrm{Ck}$ & $6.3 \pm 0.9$ & $8.1 \pm 0.3$ & $0.12 \pm 0.02$ & $0.03 \pm 0.0$ & $7.9 \pm 1.4$ & $13.2 \pm 2.5$ & $19.0 \pm 3.4$ & $0.1 \pm 0.01$ & $2.1 \pm 0.2$ \\
\hline & & $\mathrm{Ab}$ & $7.5 \pm 0.7$ & $7.9 \pm 0.4$ & $0.10 \pm 0.01$ & $0.16 \pm 0.0$ & $15.9 \pm 3.4$ & $12.7 \pm 1.3$ & $18.2 \pm 2.1$ & $0.2 \pm 0.01$ & $2.6 \pm 0.4$ \\
\hline \multirow{4}{*}{$\begin{array}{l}2007-2016 \\
(\leq 10 \text { yr of } \\
\text { cultivation) }\end{array}$} & \multirow{4}{*}{$\begin{array}{l}\text { VII } \\
\text { Alluvial } \\
\text { plain } \\
\text { (Midland) }\end{array}$} & Ap & $4.0 \pm 1.7$ & $7.6 \pm 0.3$ & $0.27 \pm 0.03$ & $0.12 \pm 0.02$ & $11.1 \pm 2.5$ & $11.9 \pm 2.1$ & $15.2 \pm 1.8$ & $0.1 \pm 0.01$ & $3.7 \pm 0.6$ \\
\hline & & $\mathrm{C} 1$ & $3.7 \pm 2.4$ & $7.5 \pm 0.4$ & $0.20 \pm 0.04$ & $0.11 \pm 0.01$ & $7.9 \pm 1.3$ & $13.7 \pm 3.1$ & $17.2 \pm 2.9$ & $0.2 \pm 0.03$ & $3.1 \pm 0.8$ \\
\hline & & $\mathrm{Ab}$ & $3.9 \pm 2.6$ & $7.8 \pm 0.2$ & $0.21 \pm 0.06$ & $0.13 \pm 0.02$ & $13.8 \pm 2.1$ & $12.4 \pm 2.1$ & $18.9 \pm 4.6$ & $0.4 \pm 0.02$ & $2.1 \pm 0.4$ \\
\hline & & $\mathrm{C} 2$ & $2.5 \pm 1.6$ & $7.4 \pm 0.3$ & $0.09 \pm 0.02$ & $0.06 \pm 0.01$ & $5.4 \pm 0.8$ & $10.9 \pm 1.4$ & $19.1 \pm 3.1$ & $0.1 \pm 0.01$ & $2.5 \pm 0.6$ \\
\hline \multirow{17}{*}{$\begin{array}{l}\text { Native land } \\
\text { (Not- } \\
\text { agricultural } \\
\text { land) }\end{array}$} & \multirow{4}{*}{$\begin{array}{l}\text { VIII } \\
\text { Alluvial } \\
\text { plain } \\
\text { (Midland) }\end{array}$} & $\mathrm{C} 1$ & $0.4 \pm 0.1$ & $7.5 \pm 0.4$ & $0.25 \pm 0.01$ & $0.09 \pm 0.01$ & $9.5 \pm 1.4$ & $13.8 \pm 1.8$ & $23.2 \pm 2.9$ & $0.2 \pm 0.01$ & $3.3 \pm 0.9$ \\
\hline & & $\mathrm{C} 2$ & $0.1 \pm 0.0$ & $7.4 \pm 0.2$ & $0.16 \pm 0.02$ & $0.06 \pm 0.02$ & $6.2 \pm 1.1$ & $12.7 \pm 2.0$ & $25.0 \pm 4.1$ & $0.0 \pm 0.0$ & $2.9 \pm 0.8$ \\
\hline & & $\mathrm{Ab}$ & $1.6 \pm 0.4$ & $7.6 \pm 0.1$ & $0.19 \pm 0.01$ & $0.10 \pm 0.01$ & $12.4 \pm 3.7$ & $12.4 \pm 2.1$ & $22.1 \pm 2.6$ & $0.1 \pm 0.01$ & $1.5 \pm 0.4$ \\
\hline & & $2 \mathrm{C}$ & $0.1 \pm 0.1$ & $7.6 \pm 0.2$ & $0.07 \pm 0.0$ & $0.03 \pm 0.01$ & $4.5 \pm 2.4$ & $11.9 \pm 1.7$ & $20.9 \pm 3.1$ & $0.2 \pm 0.02$ & $2.3 \pm 0.3$ \\
\hline & \multirow{4}{*}{$\begin{array}{l}\text { IX } \\
\text { Piedmont } \\
\text { slope } \\
\text { (Upland) }\end{array}$} & $\bar{C}$ & $0.2 \pm 0.0$ & $8.1 \pm 0.4$ & $0.23 \pm 0.01$ & $0.06 \pm 0.01$ & $8.1 \pm 2.1$ & $13.4 \pm 2.1$ & $25.1 \pm 3.4$ & $0.3 \pm 0.02$ & $3.1 \pm 1.1$ \\
\hline & & $\mathrm{Ck}$ & $0.7 \pm 0.2$ & $8.3 \pm 0.5$ & $0.15 \pm 0.02$ & $0.03 \pm 0.0$ & $7.1 \pm 1.9$ & $13.1 \pm 0.9$ & $27.2 \pm 5.7$ & $0.5 \pm 0.03$ & $3.0 \pm 0.8$ \\
\hline & & Ckkm & $0.6 \pm 0.3$ & $8.4 \pm 0.2$ & $0.11 \pm 0.01$ & $0.03 \pm 0.0$ & $6.7 \pm 2.1$ & $12.8 \pm 1.2$ & $34.1 \pm 3.7$ & $0.0 \pm 0.0$ & $3.3 \pm 0.9$ \\
\hline & & $\mathrm{Ckm}$ & $0.1 \pm 0.0$ & $8.0 \pm 0.1$ & $0.08 \pm 0.0$ & $0.01 \pm 0.0$ & $6.1 \pm 1.7$ & $12.4 \pm 1.5$ & $27.7 \pm 5.1$ & $0.0 \pm 0.0$ & $2.7 \pm 0.6$ \\
\hline & \multirow{4}{*}{$\begin{array}{l}\mathrm{X} \\
\text { Piedmont } \\
\text { slope } \\
\text { (Upland) }\end{array}$} & $\mathrm{C}$ & $0.1 \pm 0.0$ & $7.6 \pm 0.3$ & $0.07 \pm 0.02$ & $0.01 \pm 0.0$ & $6.4 \pm 1.7$ & $12.6 \pm 2.4$ & $31.1 \pm 3.8$ & $0.1 \pm 0.01$ & $3.2 \pm 0.4$ \\
\hline & & $\mathrm{Ck}$ & $0.6 \pm 0.1$ & $7.7 \pm 0.5$ & $0.05 \pm 0.01$ & $0.02 \pm 0.0$ & $5.9 \pm 1.4$ & $12.4 \pm 2.5$ & $27.2 \pm 3.9$ & $0.3 \pm 0.02$ & $3.1 \pm 0.5$ \\
\hline & & $\mathrm{Ckm}$ & $0.1 \pm 0.0$ & $7.8 \pm 0.4$ & $0.01 \pm 0.0$ & $0.02 \pm 0.0$ & $5.4 \pm 0.8$ & $12.2 \pm 2.1$ & $33.1 \pm 4.5$ & $0.2 \pm 0.01$ & $2.9 \pm 0.3$ \\
\hline & & $2 \mathrm{C}$ & $0.2 \pm 0.0$ & $7.4 \pm 0.5$ & $0.01 \pm 0.0$ & $0.01 \pm 0.0$ & $4.1 \pm 0.9$ & $11.9 \pm 2.4$ & $25.7 \pm 3.1$ & $0.1 \pm 0.01$ & $2.7 \pm 0.1$ \\
\hline & \multirow{3}{*}{$\begin{array}{l}\text { XI } \\
\text { Mountains } \\
\text { (Upland) }\end{array}$} & $\mathrm{C}$ & $0.3 \pm 0.1$ & $8.1 \pm 0.4$ & $0.05 \pm 0.0$ & $0.01 \pm 0.0$ & $4.5 \pm 1.1$ & $10.9 \pm 1.8$ & $27.1 \pm 5.3$ & $0.0 \pm 0.0$ & $1.8 \pm 0.3$ \\
\hline & & $2 \mathrm{C}$ & $0.3 \pm 0.0$ & $8.2 \pm 0.3$ & $0.02 \pm 0.0$ & $0.01 \pm 0.0$ & $4.1 \pm 0.8$ & $10.6 \pm 1.9$ & $35.7 \pm 7.1$ & $0.0 \pm 0.0$ & $2.6 \pm 0.9$ \\
\hline & & $3 \mathrm{Cr}$ & $0.2 \pm 0.0$ & $7.9 \pm 0.4$ & $0.01 \pm 0.0$ & $0.0 \pm 0.0$ & $3.4 \pm 0.7$ & $11.1 \pm 1.2$ & $26.5 \pm 6.4$ & $0.0 \pm 0.0$ & $2.9 \pm 0.4$ \\
\hline & \multirow{2}{*}{$\begin{array}{l}\text { XII } \\
\text { Mountains }\end{array}$} & $\mathrm{C}$ & $0.1 \pm 0.0$ & $8.0 \pm 0.3$ & $0.01 \pm 0.0$ & $0.01 \pm 0.0$ & $3.2 \pm 0.6$ & $9.5 \pm 0.4$ & $25.4 \pm 5.1$ & $0.0 \pm 0.0$ & $1.3 \pm 0.1$ \\
\hline & & $\mathrm{Cr}$ & $0.0 \pm 0.0$ & $8.1 \pm 0.2$ & $0.01 \pm 0.0$ & $0.0 \pm 0.0$ & $3.1 \pm 0.4$ & $8.1 \pm 0.9$ & $36.1 \pm 4.2$ & $0.0 \pm 0.0$ & $1.1 \pm 0.2$ \\
\hline
\end{tabular}




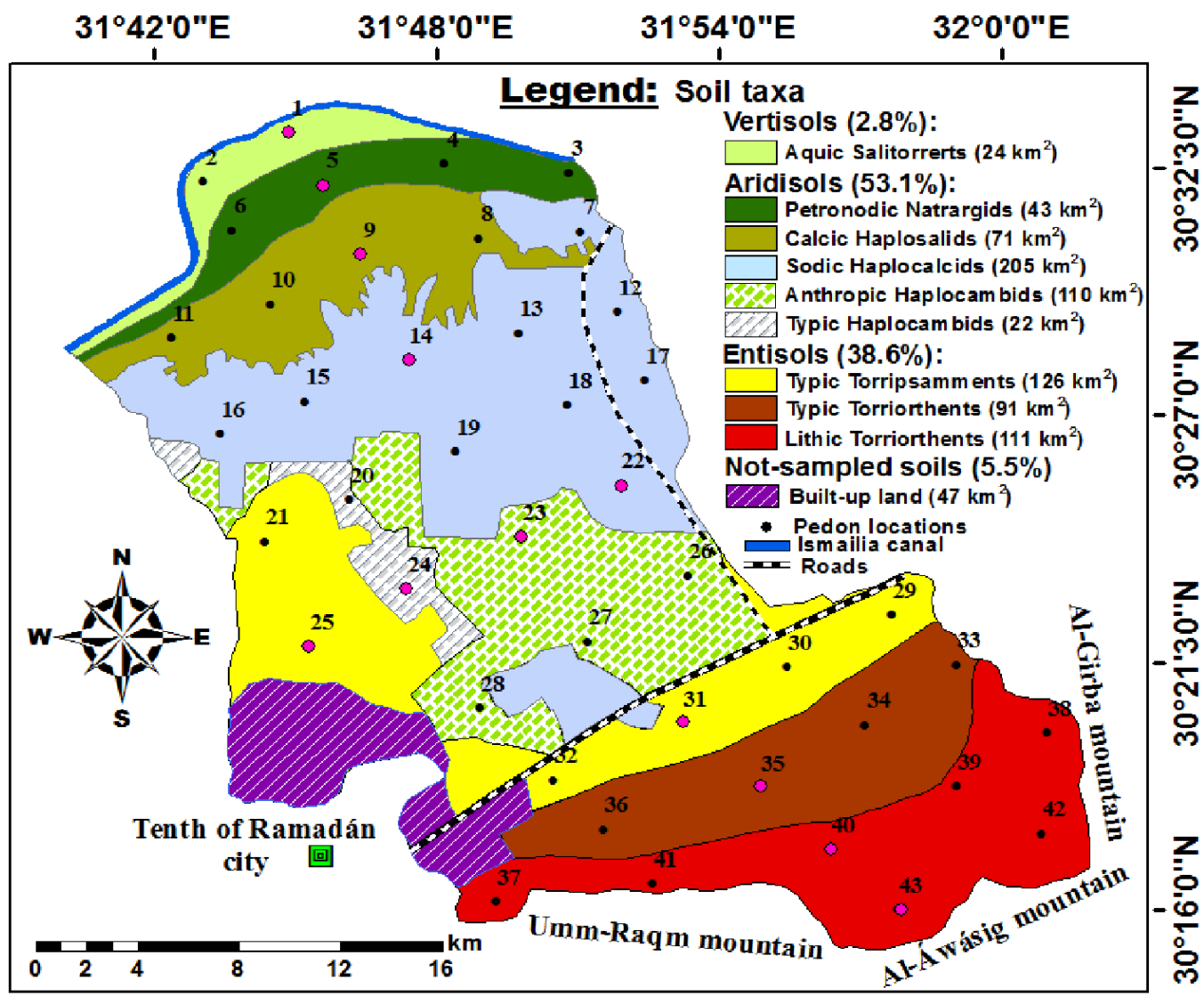

Fig. (8): Soil classification change across native and cultivated landscapes over cultivation periods in the Wadi AlMolak catena

Table (6): Distribution of soil taxonomic classes and soil morphological features across the landscapes representing different ages of cultivation in Wadi Al-Molak

\begin{tabular}{|c|c|c|c|c|c|c|c|c|c|c|c|c|c|c|c|}
\hline \multirow{2}{*}{$\begin{array}{l}\text { Soil } \\
\text { classification }\end{array}$} & \multirow{2}{*}{ Soil features } & \multirow{2}{*}{ 光 } & \multirow{2}{*}{ 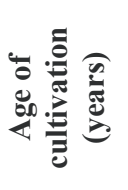 } & \multicolumn{2}{|c|}{$\begin{array}{l}\text { Total study } \\
\text { area }\end{array}$} & \multicolumn{2}{|c|}{$\begin{array}{c}\text { Nile old } \\
\text { deltaic plain }\end{array}$} & \multicolumn{2}{|c|}{$\begin{array}{l}\text { Bajada } \\
\text { plain }\end{array}$} & \multicolumn{2}{|c|}{$\begin{array}{l}\text { Alluvial } \\
\text { plain }\end{array}$} & \multicolumn{2}{|c|}{$\begin{array}{l}\text { Piedmont } \\
\text { slope }\end{array}$} & \multicolumn{2}{|c|}{ Mountains } \\
\hline & & & & 포 & $\theta^{\ominus}$ & IE & $\partial^{0}$ & 프 & $\theta^{\theta}$ & 로 & $a^{\circ}$ & Ẽ & $\theta^{\theta}$ & E & $\partial^{0}$ \\
\hline Vertisols & \multirow{2}{*}{$\begin{array}{c}\text { Argillic/Salic/ } \\
\text { Anthraquic } \\
\text { condition }\end{array}$} & & & 24 & 2.8 & 24 & 35.8 & 0 & 0 & 0 & 0 & 0 & 0 & 0 & 0 \\
\hline $\begin{array}{l}\text { Aquic } \\
\text { Salitorrerts } \\
\end{array}$ & & I & $>30$ & 24 & 2.8 & 24 & 35.8 & 0 & 0 & 0 & 0 & 0 & 0 & 0 & 0 \\
\hline \multicolumn{4}{|l|}{ Aridisols } & 451 & 53.1 & 43 & 64.2 & 87 & 100 & 306 & 76.5 & 15 & 8.1 & 0 & 0 \\
\hline \multirow{5}{*}{$\begin{array}{l}\text { Petronodic } \\
\text { Natrargids } \\
\text { Calcic } \\
\text { Haplosalids } \\
\text { Sodic } \\
\text { Haplocalcids } \\
\text { Anthropic } \\
\text { Haplocambid } \\
\text { Typic } \\
\text { Haplocambid } \\
\end{array}$} & \multirow{4}{*}{$\begin{array}{c}\text { Argillic/Natric } \\
\text { Salic/Calcic/N } \\
\text { atric } \\
\text { Calcic / sodic } \\
\text { condition } \\
\text { Cambic/Anthr } \\
\text { opic }\end{array}$} & II & $>30$ & 43 & 5.1 & 43 & 64.2 & 0 & 0 & 0 & 0 & 0 & 0 & 0 & 0 \\
\hline & & III & $>30$ & 71 & 8.4 & 0 & 0 & 71 & 81.6 & 0 & 0 & 0 & 0 & 0 & 0 \\
\hline & & IV,V & $21->30$ & 205 & 24.1 & 0 & 0 & 16 & 18.4 & 182 & 45.5 & 7 & 3.8 & 0 & 0 \\
\hline & & VI & $20-11$ & 110 & 12.9 & 0 & 0 & 0 & 0 & 102 & 25.5 & 8 & 4.3 & 0 & 0 \\
\hline & Cambic & VII & $\leq 10$ & 22 & 2.6 & 0 & 0 & 0 & 0 & 22 & 5.5 & 0 & 0 & 0 & 0 \\
\hline \multicolumn{2}{|l|}{ Entisols } & & \multirow{4}{*}{$\begin{array}{l}\text { Not- } \\
\text { used } \\
\text { lands } \\
\text { (Native } \\
\text { soil) } \\
\end{array}$} & 328 & 38.6 & 0 & 0 & 0 & 0 & 59 & 14.8 & 158 & 85.4 & 111 & 100 \\
\hline \multirow{3}{*}{$\begin{array}{l}\text { Typic } \\
\text { Torripsamme } \\
\text { Typic } \\
\text { Torriorthents } \\
\text { Lithic } \\
\text { Torriorthents } \\
\end{array}$} & \multirow{3}{*}{$\begin{array}{c}\text {-- } \\
\text { Weathered } \\
\text { bedrocks } \\
\text { Lithic } \\
\text { contact/bedroc }\end{array}$} & $\begin{array}{l}\text { VIII, } \\
\text { IX }\end{array}$ & & 126 & 14.8 & 0 & 0 & 0 & 0 & 59 & 14.8 & 67 & 36.2 & 0 & 0 \\
\hline & & $\mathrm{X}$ & & 91 & 10.7 & 0 & 0 & 0 & 0 & 0 & 0 & 91 & 49.2 & 0 & 0 \\
\hline & & $\begin{array}{l}\text { XI, } \\
\text { XII } \\
\end{array}$ & & 111 & 13.1 & 0 & 0 & 0 & 0 & 0 & 0 & 0 & 0 & 111 & 100 \\
\hline $\begin{array}{l}\text { Built-up } \\
\text { land }\end{array}$ & Not & mpled & & 50 & 5.9 & 0 & 0 & 0 & 0 & 35 & 8.8 & 15 & 8.1 & 0 & 0 \\
\hline
\end{tabular}


along a macropore, followed by a downward movement as a suspended load in leaching pore water, and ending with deposition (Phillips, 2007). Mineral transformation during pedogenesis was another mechanism for argillic horizon formation. For example, silt-sized mica may weather in situ to clay-sized illite, which increases the clay content of the horizon (Jackson, 1965). The presence of argillic horizons (Fig. 5), therefore, indicated long-term fertigation and geomorphic stability throughout the Holocene-aged Neonile or longer (Hirmas and Graham, 2011; El-Bastawesy et al., 2016).

Salic horizons (e.g., Bssz and Btnz) occurred in $11.2 \%$ of the total study area and distributed evenly across two landscapes, ranging from $35.8 \%$ of Nile old deltaic plain (dipped delta as a geomorphic component) to $81.6 \%$ of bajada plain soils (Table 6 and Figs. 5a, c).

Salic horizon was mainly originated from the continuous chemical fertilization under flooding conditions, the common practice for rice irrigation in the lowland, (Wopereis et al., 1992). The solutes supplied by the irrigation water and chemical fertilizers were accumulated in the upper solum (e.g., Apzg and Btg horizons), which attributed to the blocked downward water transfer during the practice of wet soiltillage (puddling) (Boivin et al., 2002) forming an increase of the puddled soil layer depth; e.g., Btk and Btkm horizons (Fig. 5a). These horizons were cemented by the accumulation of carbonates and iron oxides (Wopereis et al., 1992). Furthermore, natric horizons occurred only in $13.5 \%$ of the total study area, distributed as $64.2 \%$ of Nile old deltaic plain $\left(43 \mathrm{~km}^{2}\right)$ and $81.6 \%$ of bajada plain $\left(71 \mathrm{~km}^{2}\right)$. Therefore, drainage control of rice fields is of primary significance in order to avoid land degradation by soil salinization and sodification (Boivin et al., 2002).

Calcic horizons were identified in $32.5 \%$ of the total study area (Table 6 and Figs. 5, 6). They were distributed evenly across lower landscapes, ranging in frequency from $45.5 \%$ in alluvial plain soils to $100 \%$ in bajada plain soils. $15.5 \%$ of the total study area plain also contained soils with cambic horizons which were formed during the long-term 10-20 yr, distributed on alluvial plain $\left(124 \mathrm{~km}^{2}\right)$ and piedmont slope $\left(8 \mathrm{~km}^{2}\right)$. The presence of calcic horizons on these landscapes not only indicates that the soils have some stability, but that they are influenced by dust influx and eolian inputs of $\mathrm{CaCO}_{3}$ (Hirmas and Graham, 2011). Such areas of disturbance (e.g., mountains and piedmont slope landscapes) are more vulnerable to wind or water erosion, which may explain, in part, the absence of calcic horizons in the eroded landscapes at upland. Furthermore, calcic horizons were also absent at lowland due to the decalcification process induced by human interventions (Van den Berg and Loch, 2000).

\section{Impacts on soil taxa change}

Soils under cultivation on alluvial plain had cambic or calcic horizons resulting from long-term irrigation and fertilization. This change led to classify these soils into Aridisols compared with native soils which classified as Entisols. Furthermore, soil moisture regime was changed from aridic to anthraquic as a result of flood irrigation in lowland soils under rice cultivation developed anaerobic conditions in the upper parts of the pedon (e.g., Apzg and Btg) (Fig. 5a). These soils were changed from their natural status to Vertisols with anthraquic saturation. An anthraquic soil moisture regime is a special kind of aquic condition occurred under flood irrigated soils (Soil Survey Staff, 2014c). Since three types of saturation (Episaturation, Endosaturation, and Anthric saturation) are defined in the Soil Taxonomy of which the first two are considered at great group level while the third needs to be included. For example, Epiaquert and Endoaquert great groups of Vertisols are in use; however, a great group to consider anthric saturation in Torrerts suborder (For instance, Anthritorrerts) is still needed. However, soils of dipped delta considered to be irrigation water aquic could not be properly classified at the subgroup level, since the anthraquic subgroups are not set up for Vertisols. Where the Anthraquic subgroups have been only considered in six orders (e.g., Alfisols, Andisols, Entisols, Inceptisols, Mollisols, and Ultisols) and ignored in Vertisols and Aridisols. Hence, anthraquic saturation should be also considered as a subgroup in Salitorrerts great group. Hence, the current study suggests that soils similar to the dipped delta need to be classified as Salic Anthritorrerts or Anthraquic Salitorrerts instead of Aquic Salitorrerts (Table 6) due to the "aquic" only is a broader term which varies and is not specified (Soil Survey Staff, 2014c). Therefore, the USDA Soil Taxonomy should be modified; adding new classes to better classify Vertisols and Aridisols that are highly affected by human activities.

\section{CONCLUSION}

Both time series Landsat images technique and paired-site approach were successfully applied to characterize the anthropogenic impacts on land cover change and whole pedon change, respectively, from 1986 to 2016 across different landscapes in Wadi AlMolak catena, Egypt. Native and cultivated soils were carefully selected for comparison. Understanding native soil variability is critical as a basis for understanding changes in soil properties resulting from cultivation. The agricultural land expanded from $225 \mathrm{~km}^{2}$ in 1986 at lowland to $475 \mathrm{~km}^{2}$ in 2016 on the alluvial plain landscape. The study projected that the soil and irrigation water potentialities played a critically important role in this expansion. The majority of soils cultivated in different epochs occurred on the alluvial plain landscape. Results comparisons revealed changes in soil properties by slope position within a site and wide changes resulting from cultivation. The results showed broad differences in the morphological, physical, and chemical properties of cultivated soils compared with the native land. The study highlights the importance of studying the complete soil solum or whole pedon when characterizing and quantifying soil change. Pedon horizonation change and formation of new diagnostic horizons during a short period of time show that the human activity has a great impact on the soil as anthropedogenisis. The cultivated landscapes had specific diagnostic horizons (e.g., argillic, natric, and 
salic) as a result of long-term cultivation ( $>30$ years). Some of these horizons (e.g., natric and salic) reflected the degradation process resulting from over-use chemical fertilizers and intensive irrigation, particularly saline groundwater. Pedons under $\leq 10,11-20,21-30$ years of cultivation showed increasing in solum thickness with increasing cultivation time, whereas the native soils lacked to have any diagnostic horizons. Soil bulk density $(\rho b)$, for the surface horizons, generally decreased downslope from 1.65 to $0.95 \mathrm{~g} \mathrm{~cm}^{-3}$ at the mountains and alluvial plain landscapes, respectively, and then increased in the lowland soils (1.17-1.45 g $\mathrm{cm}^{-3}$ ), indicated physical degradation process induced by mismanagement. STN followed the same distribution of SOC across the toposequence and within pedons.

The current study highlights the importance of having appropriate baseline sites (native lands); understanding soil variability and anthropogenic impacts on that variability; studying the whole pedon; studying soil-landscapes or catenas; having appropriate spatial units (e.g., hillslope components). Scientific knowledge of soil formation processes in relation to natural and human-altered pathways is essential to the restoration of ecosystems and the development of sustainable land use. Furthermore, improved soil, water, and crop management practices with associated technologies intervention can help reduce degradation, improve crop productivity, and sustain soil quality. The results of the current study found that agricultural expansion had major change in the land cover, soil morphological, physical, and chemical properties, even the pedon horizonation. These results are very valuable for better understanding soil genesis and evolution with agricultural utilization.

\section{REFERENCES}

Abd-Allah, A. M. A., M. H. Abdel-Aal and A. Ghandour (2012). Structural characteristics and tectonic evolution of the northwestern margin of the Nile Delta, Egypt. J. Afr. Earth Sci., 68: 82-95.

Artieda, O., J. Herrero and P. Drohan (2006). Refinement of the differential water loss method for gypsum determination in soils. Soil Sci. Soc. Am. J., 70(6): 1932-1935.

Ayers, R. S. and D. W. Westcot (1985). Water Quality for Agriculture. FAO Irrigation and drainage paper No. 29 Rev. 1. Rome, FAO.

Boivin, P., F. Favre, C. Hammecker, J. L. Maeght, J. Delariviére, J. C. Poussin and M. C. S. Wopereis (2002). Processes driving soil solution chemistry in a flooded rice-cropped Vertisols: Analysis of long-time monitoring data. Geoderma, 110: 87-107.

Chirinda, N., L. Elsgaard, I. K. Thomsen, G. Heckrath and J. E. Olesen (2014). Carbon dynamics in topsoil and subsoil along a cultivated toposequence. Catena, 120: 20-28.

Crutzen, P. J. (2006). The "Anthropocene". In: Ehlers, E., Krafft, T., Moss, C. (Eds.), Earth System
Science in the Anthropocene. Springer Berlin Heidelberg, pp. 13-18.

Dudal, R. (2005). The sixth factor of soil formation. Eurasian Soil Sci., 38: S60.

Egyptian Meteorological Authority (2016). Climatic Atlas of Egypt, Cairo, Egypt.

El-Bastawesy, M., O. H. Cherif and M. Sultan (2016). The geomorphological evidence of subsidence in the Nile Delta: Analysis of high-resolution topographic DEM and multitemporal satellite images, J. African Earth Sci., 55: 1-10.

Ellis, S. and A. Mellor (1995). Soils and Environment. Routledge, New York.

El-Shazly, E. M., M. A. Abdel Hady, M. M. El-Shazly, M. A. El-Ghawabby, I. A. El-Kassas, A. B. Salman and M. A. Morsi (1975). Geological and groundwater potential studies of El Ismailia master plan study area. Remote Sensing Research Project, Academy of Scientific Research and Technology, Cairo, Egypt.

FAO (2006). Guidelines for Soil Description. $4^{\text {th }}$ Edition. Food and Agriculture Organization of the United Nations, Rome, Italy.

Gad, M. I., M. M. El-Kammar and H. M. G. Ismail (2015). Groundwater Vulnerability Assessment Using Different Overlay and Index Methods for Quaternary Aquifer of Wadi El-Tumilat, East Delta, Egypt. Asian Rev. Environ. Earth Sci., 2(1): 9-22.

Geological Survey and Mining Authority (1981). Geological Map of Egypt. Scale 1:2.000.000, Cairo, Egypt.

Grieve, I. C. (2001). Human impacts on soil properties and their implications for the sensitivity of soil systems in Scotland. Catena, 42: 361374.

Grossman, R. B. and T. G. Reinsch (2002). Bulk density and linear extensibility. In: Dane, J.H. and G. C. Topp (Eds.), Methods of Soil Analysis. Part 4. SSSA Book Ser. 5. SSSA, Madison, WI, pp. 201-225.

Hirmas, R. D. and C. R. Graham (2011). Pedogenesis and Soil-Geomorphic Relationships in an Arid Mountain Range, Mojave Desert, California. Soil Sci. Soc. Am. J., 75: 192 206.

Huang, L. M., A. Thompson, G. Zhang, L. M. Chen, G. Z. Han and Z. T. Gong (2015). The use of chronosequences in studies of paddy soil evolution: a review. Geoderma, 237-238: 199-210.

Indorante, S. J., J. M. Kabrick, B. D. Lee and J. M. Maatta (2014). Quantifying soil profile change caused by land use in Central Missouri Loess Hillslopes. Soil Sci. Soc. Am. J., 78(1): 225-237.

Jackson, M. L. (1965). Clay transformation in soil genesis during the Quaternary. Soil Sci., 99: $15-22$. 
Jenny, H. (1941). Factors of soil formation: A system of quantitative pedology. McGraw Hill, New York.

Juilleret, J., S. Dondeyne, K. Vancampenhout, J. Deckers and C. Hissler (2016). Mind the gap: a classification system for integrating the subsolum into soil surveys. Geoderma http://dx.doi.org/10.1016/j.geoderma.

Khalaf, S. and M. I. Gad (2015). Modeling of contaminant transport in 10th of Ramadan City Area, East Delta, Egypt. Int. J. Water Resources and Environ. Engineering, 7(10): 139-152.

Khalifa, M. A. and E. H. Mohamed (2008). Minimum data set approach using principal components analysis for land productivity assessment at Wadi El-mollak area, east of Delta, Egypt. J. Agric. Environ. Sci. Alex. Univ., 7(3): 205219.

Khalil, M. M., T. Tokunaga and A. F. Yousef (2015). Insights from stable isotopes and hydrochemistry to the Quaternary groundwater system, south of the Ismailia canal, Egypt. J. Hydrol., 527: 555-564.

Khresat, S., J. Al-Bakri and R. Al-Tahnan (2008). Impacts of land use/cover change on soil properties in the Mediterranean region of northwestern Jordan. Land Degrad. Dev., 19 (4): 397-407.

Kögel-Knabner, I., W. Amelung, Z. Cao, Z. Cao, S. Fiedler, P. Frenzel, R. Jahn, K. Kalbitz, A. Kölbl and M. Schloter (2010). Biogeochemistry of paddy soils. Geoderma, 157: 1-14.

Kołodyńska-Gawrysiak, R., J. Chodorowski, P. Mroczek, A. Plak, W. Zgłobicki, A. Kiebała, J. Trzciński and K. Standzikowski (2017). The impact of natural and anthropogenic processes on the evolution of closed depressions in loess areas. A multi-proxy case study from Nałęczów Plateau, Eastern Poland. Catena, 149:1-18.

Kuang, W., J. Liua, J. Dong, W. Chi and C. Zhang (2016). The rapid and massive urban and industrial land expansions in China between 1990 and 2010: A CLUD-based analysis of their trajectories, patterns, and drivers. Landscape and Urban Planning, 145:21-33.

Mabrouk, B., F. Ramadan, M. Nagaty and Y. Abd ElAzeem (2016). Sedimentological and Hydrogeochemical Studies of the Quaternary Groundwater Aquifer in El Salhyia Area, Sharkia Governorate, Egypt, Middle East J. Appl. Sci., 6(1): 120-138.

Mehra, O. P. and M. L. Jackson (1960). Iron oxide removal from soils and clays by a dithionitecitrate system buffered with sodium bicarbonate. Clay Miner., 7: 317-327.

Moragues-Quiroga, C., J. Juilleret, L. Gourdol, E. Pelt, T. Perrone, A. Aubert, G. Morvan, F. Chabaux, A. Legout, P. Stille and C. Hissler (2017). Genesis and evolution of regoliths:
Evidence from trace and major elements and Sr-Nd-Pb-U isotopes. Catena, 149: 185-198.

Munsell Color (2009). Munsell Soil-Color Charts with Genuine Munsell Color Chips. 2009 Year Revised/2010 Production. Gretagmacbeth. New Windsor, NY. www.munsell.com

Nelson, D. W. and L. E. Sommers (1996). Total carbon, organic carbon and organic matter: laboratory methods, In: Sparks et al. (Eds.), Methods of Soil Analysis, Part 3, 3rd ed. SSSA Book Ser. 5. SSSA, Madison, WI., pp. 961-1010.

Nettleton, W. D., J. E. Witty, R. E. Nelson and J. W. Hawley (1975). The genesis of argillic horizons in soils of desert areas of the southwestern United States. Soil Sci. Soc. Am. $\quad$ Proc., 39: 919-926. doi:10.2136/sssaj1975.036159950039000500 $35 \mathrm{x}$.

Ozpinar, S., A. Ozpinar and A. Cay (2018). Soil management effect on soil properties in traditional and mechanized vineyards under a semiarid Mediterranean environment. Soil Tillage Res., 178: 198-208.

Pansu, M. and J. Gautheyrou (2006). Handbook of Soil Analysis: Mineralogical, Organic and Inorganic Methods. Springer, Berlin, Germany.

Peterson, F. F. (1981). Landforms of the Basin and Range Province: Defined for soil survey. Tech. Bull. 28. Nevada Agric. Exp. Stn., Univ. of Nevada, Reno. NV. 52 p.

Phillips, J. D. (2007). Development of texture contrast soils by a combination of bioturbation and translocation. Catena, 70:92-104.

Presley, D. R., M D. Ransom, G. J. Kluitenberg and P. R. Finnell (2004). Effects of thirty years of irrigation on the genesis and morphology of two semiarid soils in Kansas. Soil Sci. Soc. Am. J., 68: 1916-1926.

Reichert, J. M., L. E. Suzuki, D. J. Reinert, R. Horn and I. Hakansson (2009). Reference bulk density and critical degree-of-compactness for no-till crop production in subtropical highly weathered soils. Soil Tillage Res., 102: 242254.

Said, R. (1993). The Nile River: Geology, Hydrology, and Utilisation. Pergamon Press, Oxford, p. 320.

Schoeneberger, P. J., D. A. Wysocki, E. C. Benham and Soil Survey Staff (2012). Field book for describing and sampling soils, Version 3.0. Natural Resources Conservation Service, National Soil Survey Center, Lincoln, NE.

Shata, A.A. and El-Fayoumy, I.F. (1970). Remarks on the regional geological structure of the Nile Delta. Symp. Hydrol. Delta, UNESCO 1: 189-197.

Soil Science Division Staff (2017). Soil survey manual. United States Department of Agriculture (USDA), Agriculture Handbook No. 18. Natural Resources Conservation Service, Washington, D.C. 
Soil Survey Laboratory Staff (2004). Soil survey laboratory methods manual. Soil Surv. Invest. Rep. 42. Version 4.0. U.S. Gov. Print. Office, Washington, DC.

Soil Survey Staff (2014a). Soil Survey Field and Laboratory Methods Manual. Soil Survey Investigations Report No. 51, Version 2.0. Washington DC: U.S. Department of Agriculture-Natural Resources Conservation Service.

Soil Survey Staff (2014b). Kellogg Soil Survey Laboratory methods manual. Soil Survey Investigations Report No. 42, version 5.0. R. Burt and Soil Survey Staff (eds.). Washington DC: U.S. Department of Agriculture-Natural Resources Conservation Service.

Soil Survey Staff (2014c). Keys to Soil Taxonomy, 12th ed. USDA-Natural Resources Conservation Service, Washington, DC.

Stanley, D. J. and A. G. Wrane (1993). Nile delta: recent geological evolution and human impact. Science, 260(5108): 628-634.

Trimble, S. W. (1974). Man-induced soil erosion on the Southern Piedmont 1700-1970. Soil Conservation Society of America, Ankeny, Iowa.

Tugel, A. J., J. E. Herrick, J. R. Brown, M. J. Mausbach, W. Puckett and K. Hipple (2005). Soil change, soil survey, and natural resources decision making. Soil. Sci. Soc. Am. J., 69: 738-747.
Tugel, A. J., S. A. Wills and J. E. Herrick (2008). Soil change guide. In: Procedures for soil survey and resource inventory. Version 1.1. National Soil Survey Center, Lincoln, NE.

Van den Berg, G.A. and J. P. G. Loch (2000). Decalcification of soils subject to periodic waterlogging. Eur. J. Soil Sci., 51: 27-33.

Wilson, M. G., M. C. Sasal and O. P. Caviglia (2013). Critical bulk density for a mollisol and a vertisol using least limiting water range. Geoderma, 192: 354-361.

Wopereis, M. C. S., J. H. M. Wösten, J. Bouma and T. Woodhead (1992). Hydraulic resistance in puddled rice soils: Measurement and effects on water movement. Soil Tillage Res., 24: 199-209.

Wysocki, D. A., P. J. Schoeneberger and H. E. LaGarry (2000). Geomorphology of soil landscapes. p. E5-E39. In M.E. Sumner (ed.) Handbook of soil science. CRC Press, Boca Raton, FL.

Yue-Qin, C., Y. Lin-Zhang, C. Zhi-Hong, C. En and Y. Shixue (2009). Chronosequential changes of selected pedogenic properties in paddy soils as compared with non-paddy soils. Geoderma, 151: 31-41.

Zilverberg, C. J., K. Heimerl, T. E. Schumacher, D. D. Malo, J. A. Schumacher and W. C. Johnson (2018). Landscape dependent changes in soil properties due to long-term cultivation and subsequent conversion to native grass agriculture. Catena, 160: 282-297. 
التأثير ات البشرية على أراضى وادى الثُلاك، غرب قناة السويس، مصر

عادل عبد الحميد علوان خليل

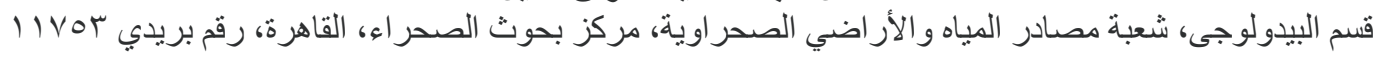

شهدت أر اضى و ادى المُلكك، غرب قناة السويس في الثلاث عقود الأخيرة طفرة زر اعية وعمر انية سريعة أثرت سلبًا أو

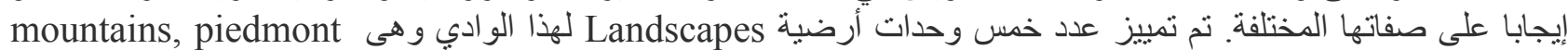
1919 slope, alluvial plain, bajada plain, and Nile old deltaic plain

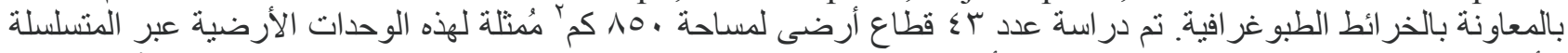

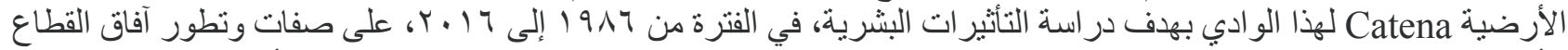

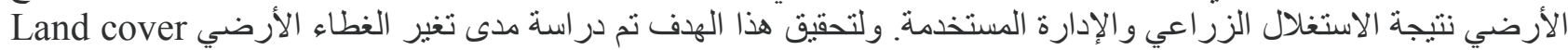

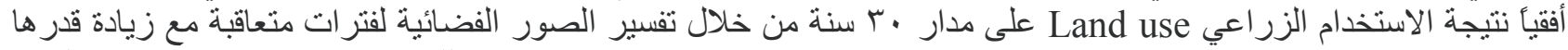

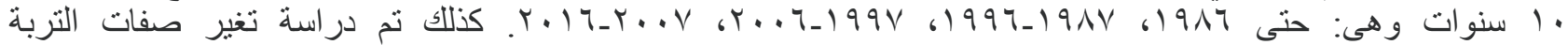
الموروفولوجية، والطبيعية، و الكيميائية رأسيا خلال آفاق القطاع الأرضي عبر الوحدات الأرضية.

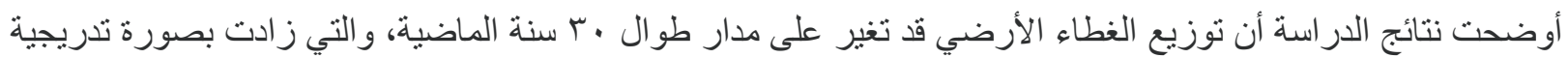

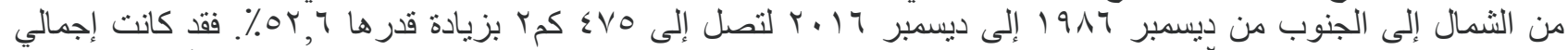

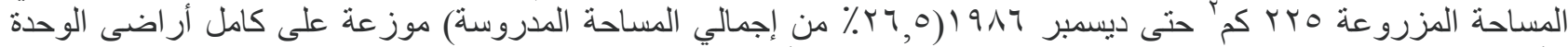

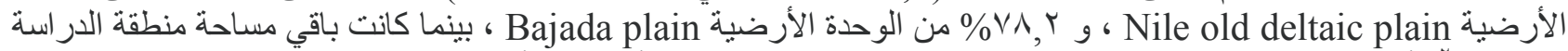

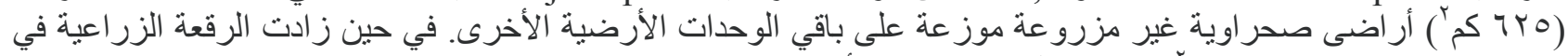

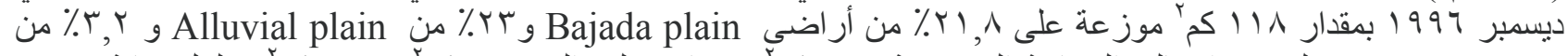
لتصبح إجمالي المساحة المزروعة r عiedmont slope

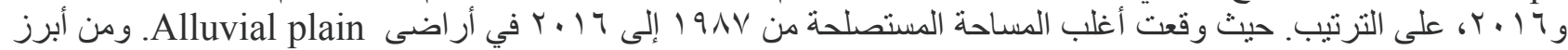

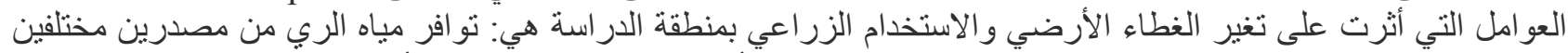

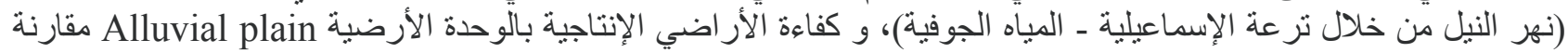

بباقي الوحدات، بالإضـافة إلى العو امل الاجتماعية والاقتصادية السياسية Socioeconomic and political measures. و من ناحية أخرى فقد أثز تغير الغطاء الأرضي إلى الغطاء النباتي بتر اكيب محصولية مختلفة، الإدارة المزرعية، وفترة وفترة

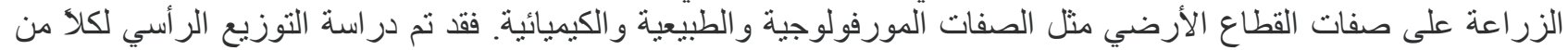

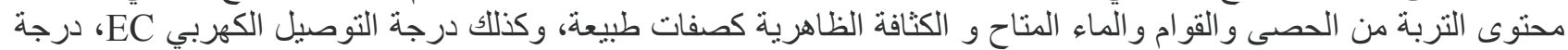

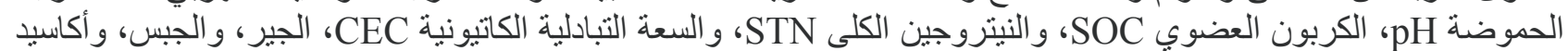

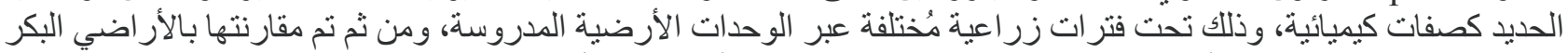

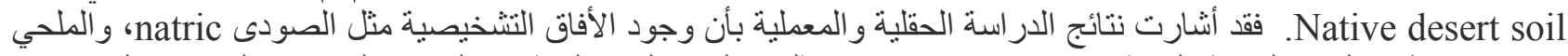
Mismanagement مدات مرثبط بعمليات الخدمة السيئة عمليات الري المكثف و التسميد الكيميائي الجائر) و الذي ساهم بشكل كبير في تدهور تللك الأراضي، بينما الأفق الطيني argillic، والأفق الكالسي calcic، مرتبط بكلا من التأثيرات التيشرية

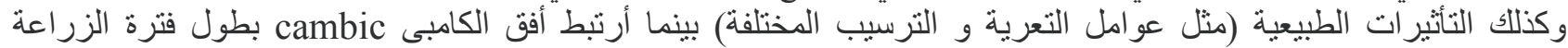

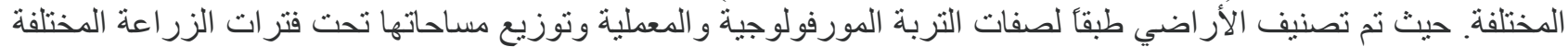

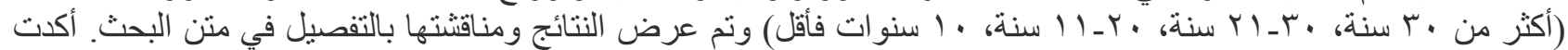

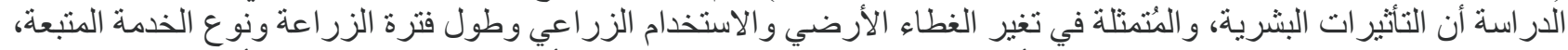

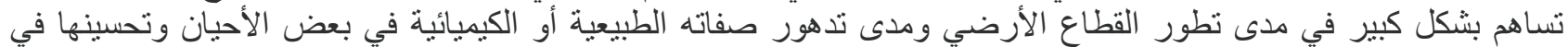

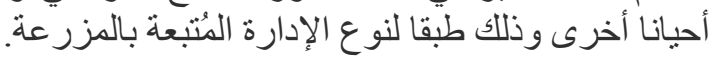

